


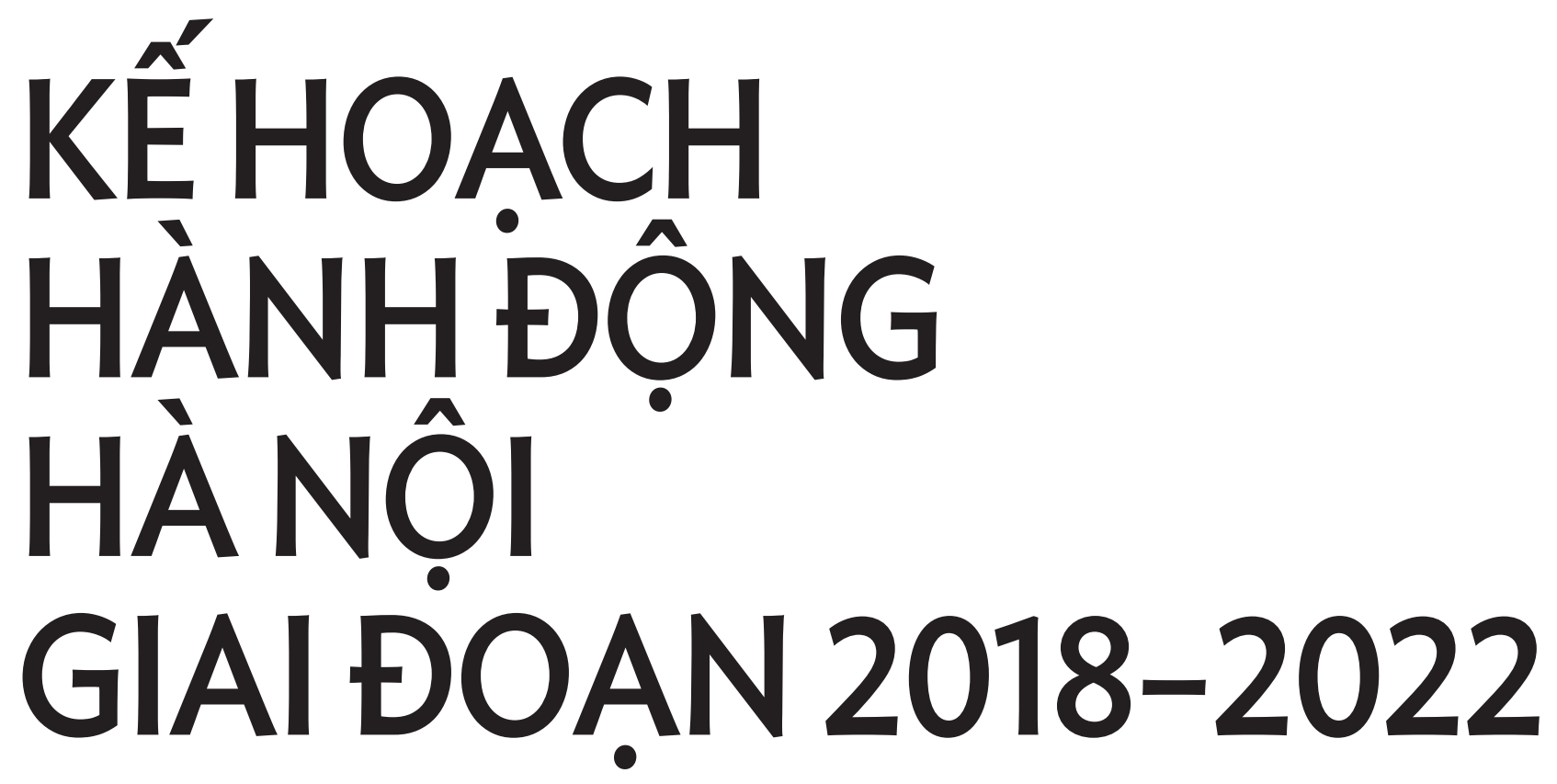

THÁNG BA, 2018
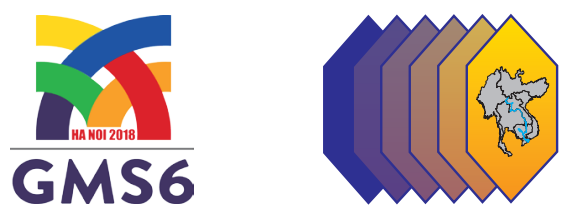
(C) 2018 Ngân hàng Phát triển Châu Á

6 ADB Avenue, Mandaluyong City, 1550 Metro Manila, Philippines

Tel +632632 4444; Fax +6326362444

www.adb.org

Bảo lưu một số quyền. Xuất bản năm 2018.

ISBN 978-92-9261-660-1 (bản in), 978-92-9261-661-8 (bản điện tử)

Số lưu chiểu: TCS190227-2

DOI: http://dx.doi.org/10.22617/TCS190227-2

Quan điểm nêu trong ấn phẩm này là của các tác giả và không nhất thiết phản ánh các quan điểm hay chính sách của Ngân hàng Phát triển Châu Á (ADB) hay Hội đồng Thống đốc của Ngân hàng hoặc các chính phủ mà họ đại diện.

ADB không bảo đảm tính chính xác của các dữ liệu trong ấn phẩm này và không chịu trách nhiệm về bất kỳ hệ quả nào từ việc sử dụng chúng. Việc đề cập các công ty hoặc sản phẩm của các nhà sản xuất cụ thể không hàm ý rằng $A D B$ ủng hộ hay khuyến nghị về họ nhiều hơn so với các công ty/sản phẩm tương đương khác không được đề cập.

Khi nêu danh hoặc tham chiếu tới một vùng lãnh thổ hoặc khu vực địa lý cụ thể, hoặc khi sử dụng từ "quốc gia” trong tài liệu này, $\mathrm{ADB}$ không có ý định đưa ra bất kỳ nhận định nào về tư cách pháp lý hoặc tư cách khác của vùng lãnh thổ hoặc khu vực địa lý đó.

Tài liệu này được cung cấp theo Giấy phép Các sản phẩm Sáng tạo chung các tổ chức liên chính phủ phiên bản 3.0 Ghi nhận công tác giả (CC BY 3.0 IGO) http://creativecommons.org/licenses/by/3.0/igo/. Với việc sử dụng nội dung của tài liệu này, người dùng đã đồng ý ràng buộc với các điều khoản của giấy phép nói trên. Về việc ghi nhận công của tác giả, dịch thuật, chuyển thể và giấy phép, xin hãy tham khảo các quy định và điều khoản sử dụng tại trang https://www.adb. org/terms-use\#openaccess.

Giấy phép Các sản phẩm Sáng tạo chung không áp dụng với các tư liệu không thuộc bản quyền của ADB trong ấn phẩm này. Nếu tư liệu được lấy từ nguồn khác, xin hãy liên hệ với chủ sở hữu tác quyền hoặc nơi xuất bản nguồn tư liệu để xin phép sử dụng. ADB không phải chịu trách nhiệm pháp lý cho bất kỳ khiếu nại nào từ việc sử dụng tư liệu đó của độc giả.

Nếu có bất kỳ câu hỏi hoặc gópý nào liên quan tới nội dung, hoặc nếu muốn xin phép bản quyền cho việc sử dụng nằm ngoài những phạm vi nêu trên, hoặc xin phép sử dụng biểu trưng của $A D B$, xin hãy liên hệ theo địa chỉ pubsmarketing@ adb.org

Lưứ:

Trong ấn phẩm này, "\$” chỉ đồng đô-la Mỹ.

Có thể tham khảo phần hiệu đính các ấn phẩm của ADB tại http://www.adb.org/publications/corrigenda

Ảnh bìa trước:

Tất cả ảnh được lấy từ $A D B$, trừ phi có ghi nhận khác.

Hàng trên, từ trái sang: Xe tải đi trên Đường Xuyên Á 131 (Tuyến 12); một quang cảnh tuyến Đường cao tốc số 12 nối đông bắc và tây bắc Thái Lan; một cơ sở kiểm tra và cách ly tại một trung tâm hậu cần của Cộng hòa Nhân dân Trung Hoa; thuyền chở du khách tới Vườn Quốc gia Phong Nha - Kẻ Bàng.

Hàng giữa, tù̀ trái sang: Nhà máy thủy điện công suất 1.070 megawatt Nam Theun 2 trên sông Nam Theun tại Cộng hòa Dân chủ Nhân dân Lào xuất khẩu 95\% lượng điện sản xuất sang Thái Lan, phần còn lại được tiêu thụ trong nước; hoạt động xây dựng hai cầu dây văng bắc qua sông Mê-kông trong khuôn khổ Dự án Kết nối khu vực trung tâm Đồng bằng sông Mê-kông, giúp kết nối hiệu quả Thành phố Hồ Chí Minh với khu vực duyên hải Nam Trung Bộ; trung tâm dành cho khách thăm quan tại Nhà máy thủy điện Nam Theun 2; cầu Tsubasa, được đưa vào sử dụng năm 2015, dọc theo Quốc lộ 1 của Cam-pu-chia nối Phnom Penh với Thành phố Hồ Chí Minh (ảnh Mardy Suong).

Hàng dưới, từ trái sang: Sompong Visetsin (bìa trái), một giảng viên về điện lạnh và các hệ thống làm mát, cùng các sinh viên của mình tại Viện Đào tạo và Giáo dục Kỹ thuật và Dạy nghề Champasak; cây cầu Nhật Tân dài 8,3km, còn gọi là Cầu Hữu nghị Việt - Nhật, là cầu dây văng bắc qua sông Hồng; đường Võ Nguyên Giáp từ trung tâm Hà Nội tới sân bay quốc tế Nội Bài được hoàn thành vào ngày 4/1/2015; Wang Shilin đang kiểm tra các hoạt động sản xuất điện trong một nhà máy ở Cộng hòa Nhân dân Trung Hoa; cảng Bo Aung Kyaw là cửa khẩu nhập hàng hóa quan trọng vào Yangon; các nữ kỹ sư trẻ tại một công trường xây dựng ở Naypyidaw, Mi-an-ma. 


\section{MỤC LỤC}

Báo cáo Tóm tắt $\quad$ viii

I. Giới thiệu

II. Khung chiến lược Tiểu vùng Mê-kông mở rộng giai đoạn 2012-2022:

Tổng quan

A. Mục tiêu và định hướng chiến lược 3

B. Khung Đầu tư vùng 4

III. Đánh giá giữa kỳ Khung chiến lược

Tiểu vùng Mê-kông mở rộng giai đoạn 2012-2022 7

A. Mục tiêu

B. Những phát hiện chính

1. Sự phù hợp của Khung chiến lược Chương trình hợp tác kinh tế Tiểu vùng Mêkông mở rộng giai đoạn 2012-2022 (GMS SF-II) với Chương trình nghị sự phát triển quốc gia

2. Sự nhất quán giữa chiến lược chung của Khung chiến lược Chương trình hợp tác kinh tế Tiểu vùng Mê-kông mở rộng giai đoạn 2012-2022 (GMS SF-II), các chiến lược ngành và các dự án trong Khung Đầu tư vùng 7

3. Hiệu quả thực thi 8

4. Các quy trình lập kế hoạch và xây dựng chương trình 12

5. Hiệu quả thể chế 13

C. Kết luận của Đánh giá giữa kỳ, khuyến nghị và bước đi tiếp theo 17

$\begin{array}{ll}\text { IV. Những diễn biến và thách thức của khu vực và toàn cầu } & 21\end{array}$

V. Kế hoạch Hành động Hà Nội 2018-2022 23

A. Khung định hướng $\quad 23$

B. Chiến lược không gian tập trung vào các hành lang kinh tế 24

C. Tinh chỉnh các chiến lược và ưu tiên của ngành 25

1. Giao thông 25

2. Phát triển đô thị, các khu kinh tế cửa khẩu và các dự án không gian đa ngành khác 27 
3. Năng lượng

5. Môi trường

6. Du lịch

7. Tạo thuận lợi thương mại

8. Phát triển nguồn nhân lực

9. Công nghệ thông tin và truyền thông

D. Cải thiện các quy trình và hệ thống lập kế hoạch, xây dựng chương trình và giám sát

E. Cải tiến những sắp xếp thể chế và quan hệ đối tác

F. Bảo đảm thực hiện thành công Kế hoạch Hành động Hà Nội giai đoạn 2018-2022

Phụ lục: Các ưu tiên hoạt động theo ngành trong Kế hoạch Hành động Hà Nội giai đoạn 2018-2022 


\section{DANH MỤC CÁC HìNH, HộP VÀ BẢNG}

Hình

1 Hình 1: Các quy trình hoạt động trong Khung Đầu tư vùng của Tiểu vùng Mê-kông mở rộng 5

2 Hình 2: Khung định hướng Kế hoạch Hành động Hà Nội 23

3 Hình 3: Tầm nhìn và các ưu tiên hoạt động của Chiến lược Giao thông I và II 26

4 Hình 4: Những đặc điểm chính của Khung chiến lược Phát triển đô thị 27

5 Hình 5: Các giai đoạn trong thiết lập thị trường điện Tiểu vùng Mê-kông mở rộng 29

6 Hình 6: Những đặc điểm chính của Chiến lược Nông nghiệp trong Tiểu vùng Mê-kông mở rộng $\quad 30$

7 Hình 7: Chuyển dịch chiến lược trong Chương trình Môi trường then chốt 31

8 Hình 8: Tinh chỉnh các Chiến lược Du lịch trong Tiểu vùng Mê-kông mở rộng 33

9 Hình 9: Những đặc điểm chính của Khung chiến lược và Kế hoạch hành động Phát triển Nguồn nhân lực trong GMS giai đoạn 2013-2017 35

10 Hình 10: Các yếu tố tạo thuận lợi cho Kế hoạch Hành động Hà Nội 38

Hộp

Các mục tiêu của Khung chiến lược Tiểu vùng Mê-kông mở rộng

Bảng

Kế hoạch Hành động Hà Nội 2018-2022 - Các ưu tiên hoạt động theo ngành 


\section{DANH MỤC CÁC TỪ VIẾT TẮT}

$\begin{array}{ll}\text { ADB } & \text { Ngân hàng Phát triển Châu Á } \\ \text { ASEAN } & \text { Hiệp hội các quốc gia Đông Nam Á } \\ \text { CBTA } & \text { Hiệp định Tạo thuận lợi vận chuyển xuyên biên giới } \\ \text { CEP } & \text { Chương trình môi trường trọng điểm } \\ \text { CEPSFAP } & \text { Khung chiến lược và Kế hoạch hành động của Chương trình môi trường trọng điểm } \\ \text { ECF } & \text { Diễn đàn các Hành lang kinh tế } \\ \text { EWEC } & \text { Hành lang kinh tế Đông - Tây } \\ \text { GMS } & \text { Tiểu vùng Mê-kông mở rộng } \\ \text { GMS-FS } & \text { Khung chiến lược Tiểu vùng Mê-kông mở rộng } \\ \text { HAP } & \text { Kế hoạch hành động Hà Nội } \\ \text { HRD } & \text { phát triển nguồn nhân lực } \\ \text { ICT } & \text { công nghệ thông tin và truyền thông } \\ \text { Lao PDR } & \text { Cộng hòa Dân chủ Nhân dân Lào } \\ \text { MTCO } & \text { Văn phòng điều phối du lịch Mê-kông } \\ \text { MTR } & \text { đánh giá giữa kỳ } \\ \text { NSEC } & \text { Hành lang kinh tế Bắc - Nam } \\ \text { PRC } & \text { Cộng hòa Dân chủ Nhân dân Trung Hoa } \\ \text { RCI } & \text { hợp tác và hội nhaâp khu vực } \\ \text { RIF } & \text { Khung Đầu tư vùng } \\ \text { RIF-IP } & \text { Kế hoạch thực hiện Khung Đầu tư vùng } \\ \text { RKC } & \text { Công ước Kyoto sửa đổi } \\ \text { RPT } & \text { thương mại năng lượng (điện) trong khu vực } \\ \text { SASRAP } & \text { Chiến lược Thúc đẩy các Chuỗi giá trị dựa trên nông nghiệp an toàn và thân thiện với } \\ \text { SEAP } & \text { môi trường trong Tiểu vùng Mê-kông mở rộng và Kế hoạch Hành động Siêm Riệp } \\ \text { SEC } & \text { các sản phẩm nông nghiệp an toàn và thân thiện với môi trường } \\ \text { SEZs } & \text { Hành lang Kinh tế phía Nam } \\ \text { SFAP } & \text { các đặc khu kinh tế } \\ \text { SMEs } & \text { Khung chiến lược và Kế hoạch hành động } \\ \text { các doanh nghiệp vừa và nhỏ }\end{array}$


SOM Hội nghị Quan chức cao cấp

SPS các tiêu chuẩn vệ sinh dịch tễ

TA hỗ trợ kỹ thuật

TFWG Nhóm công tác Tạo thuận lợi thương mại

TrSS Chiến lược Giao thông

TSS Chiến lược Du lịch

TTF tạo thuận lợi thương mại và vận chuyển

UDSF Khung chiến lược Phát triển đô thị 


\section{BÁO CÁO TÓM TẮT}

K ế hoạch Hành động Hà Nội giai đoạn 2018-2022 (HAP) phản ánh chương trình nghị sự của Chương trình Hợp tác kinh tế Tiểu vùng Mê-kông mở rộng (GMS) cho 5 năm còn lại của Khung chiến lược Chương trình Hợp tác kinh tế Tiểu vùng Mê-kông mở rộng giai đoạn 2012-2022 (GMS SF-II). GMS SF-II được nhất trí tại Hội nghị Bộ trưởng GMS lần thứ 17 trong tháng 8 năm 2011 và được thông qua tại Hội nghị Thượng đỉnh GMS lần thứ tư diễn ra cùng năm. Hội nghị Bộ trưởng GMS lần thứ 21 trong tháng 12 năm 2016 đã tán thành việc đánh giá giữa kỳ GMS SF-II với các mục tiêu sau: (i) đánh giá tiến triển đạt được cho tới nay và những công việc còn lại cần thực hiện; (ii) xác định tính hiệu quả và tính đáp ứng tiếp tục đối với các nhu cầu và ưu tiên phát triển của các quốc gia GMS; và (iii) xác định những mũi nhọn mới nổi ở cấp độ chương trình và lĩnh vực.

Đánh giá giữa kỳ (MTR) đã tập trung vào năm lĩnh vực đánh giá với những phát hiện chính dưới đây:

- S Sự phù hợp tiếp tục của GMS SF-II trong việc hỗ trợ các ưu tiên quốc gia. GMS SF-II vẫn phù hợp và đáp ứng chương trình nghị sự phát triển của các quốc gia Tiểu vùng Mê-kông mở rộng. Các quốc gia GMS đánh giá phát triển hành lang kinh tế và giao thông là những lĩnh vực hợp tác mang lại lợi ích to lớn nhất, do chúng trực tiếp hỗ trợ các chiến lược công nghiệp hóa, đa dạng hóa nền kinh tế, và hội nhập vào chuỗi giá trị của các quốc gia này.

- Sự nhất quán giữa các chiến lược của ngành và chiến lược tổng thể của Chương trình hợp tác GMS. Nhìn chung, các chiến lược tổng thể của GMS SF-II và các chiến lược ngành là nhất quán, tức là chúng được thiết lập trong mối quan hệ với nhau để hướng tới đạt được các mục tiêu chung. Tuy nhiên, việc đánh giá hiệu quả thực hiện danh mục dự án cho thấy rằng một số ưu tiên lĩnh vực được hỗ trợ mạnh mẽ hơn so với các ưu tiên khác.

- Hiệu quả thực thi. Hiệu quả thực thi trong các lĩnh vực có sự pha trộn. Những lĩnh vực có hiệu quả cao là giao thông, du lịch, nông nghiệp và môi trường. Lĩnh vực năng lượng và tạo thuận lợi thương mại có tiến triển đều đặn nhưng còn chậm. Phát triển đô thị vẫn đang ở giai đoạn đầu của việc thực hiện khung chiến lược của ngành. Lĩnh vực phát triển nguồn nhân lực gần đây đã trải qua quá trình hợp lý hóa các phương thức hợp tác trong bốn tiểu ngành của mình. Hợp tác trong lĩnh vực công nghệ thông tin và truyền thông (ICT) không có tiến triển trong bối cảnh thiếu vắng một chiến lược cập nhật, mặc dù diễn đàn thương mại điện tử do khu vực tư nhân chủ trì đã đạt được một số kết quả.

- Các quy trình lập kế hoạch và xây dựng chương trình. Chương trình hợp tác kinh tế GMS không có một quy trình lập kế hoạch và xây dựng chương trình được xác định 
rõ ràng. Khung thời gian của các chiến lược ngành rất khác nhau; các mục tiêu không được xác định bằng những nội dung có thể đo lường; và việc giám sát kết quả chưa được xây dựng và thực hiện đầy đủ. Khung Đầu tư vùng (RIF) - khuôn khổ lập kế hoạch cho việc xác định và ưu tiên các dự án - chỉ có hiệu quả rất hạn chế do phạm vi bao phủ dự án hạn hẹp (chủ yếu là các dự án do Ngân hàng Phát triển Châu Á tài trợ $[\mathrm{ADB}])$. Các tiêu chí ưu tiên hầu hết tập trung vào khả năng sẵn có nguồn tài chính, và không tính các dự án ở một số lĩnh vực.

- Hiệu quả về mặt thể chế. Các cơ chế tổ chức GMS vẫn có hiệu lực và đáp úng yêu cầu đạt được những mục tiêu theo lĩnh vực. Các cơ quan chuyên biệt đã được thành lập ở cấp độ ngành (ví dụ như Hiệp hội Đường sắt Tiểu vùng Mê-kông mở rộng, Trung tâm Điều phối thương mại điện khu vực, Văn phòng Điều phối du lịch Mê-kông). Các nhóm công tác mới đã được thành lập trong liñh vực y tế và phát triển đô thị (thay thế Nhóm công tác đô thị ban đầu vốn là diễn đàn để trao đổi thông tin và sau đó được nâng cấp thành nhóm công tác, có nhiệm vụ xây dựng và thực thi khung chiến lược đô thị). Ngoài việc tham gia các phiên họp GMS, khu vực tư nhân cũng đã tham gia các sáng kiến cụ thể. Có bằng chứng đáng khích lệ về quan hệ đối tác giữa các bên hữu quan ở cấp độ dự án, gồm cả với các nhóm cộng đồng. Vai trò của $\mathrm{ADB}$ trên cương vị nhà tài trợ chính và ban thư ký trung ương được xem là một trong những thế mạnh cốt lõi của Chương trình hợp tác kinh tế GMS.

Đoàn Đánh giá giữa kỳ kết luận rằng các mũi nhọn chiến lược của GMS SF-II vẫn phù hợp, và các quốc gia thành viên nhận rõ giá trị gia tăng của Chương trình GMS. Tuy nhiên, bối cảnh khu vực và toàn cầu đang thay đổi nhanh chóng đòi hỏi Chương trình GMS phải tái định vị và tự hoàn thiện để trở nên hiệu quả hơn.

Dựa trên những khuyến nghị từ đợt Đánh giá giữa kỳ, Kế hoạch Hành động Hà Nội (HAP) giai đoạn 2018-2022 đã được xây dựng và thảo luận tại Hội nghị Bộ trưởng GMS lần thú 22 diễn ra vào ngày 20/9/2017 tại Việt Nam. Kế hoạch Hành động Hà Nội đưa ra những định hướng và trọng tâm hoạt động cho 5 năm còn lại của GMS SF-II. Kế hoạch này đặt ra cả chương trình nghị sự chưa hoàn thành và chương trình nghị sự mở rộng cho giai đoạn trung hạn. HAP cũng định hướng cho Khung Đầu tư vùng (RIF), là cơ sở xác định các dự án đề xuất cho GMS. HAP có bốn thành phần chủ chốt sau:

(i) Một chiến lược không gian tập trung vào các hành lang kinh tế. Các hành lang kinh tế GMS được coi là một mạng lưới, thay vì các hành lang riêng rẽ độc lập. Các quy hoạch khu vực đa ngành cho những khu vực ưu tiên dọc theo hành lang (các cụm đô thị và khu vực biên giới) sẽ được xây dựng. Sẽ có sự cân bằng tốt hơn giữa khả năng kết nối với bên ngoài và kết nối nội vùng nhằm tạo điều kiện cho việc phân bổ công bằng hơn lợi ích của tăng trưởng.

(ii) Tinh chỉnh các chiến lược và ưu tiên hoạt động của ngành. Các nội dung này được tóm tắt dưới đây:

(a) Giao thông: Thúc đẩy liên kết đa phương thức, tạo thuận lợi cho vận chuyển, phát triển hậu cần, an toàn đường bộ và quản lý tài sản.

(b) Phát triển đô thị: Tập trung vào các hệ thống đô thị như một phần của quy hoạch không gian trên cơ sở toàn bộ khu vực GMS, liên kết các đô thị trong vùng.

(c) Năng lượng: Hội nhập thị trường điện vẫn là ưu tiên hàng đầu và trọng tâm sẽ là buôn bán điện trên lưới điện giữa hai quốc gia bất kỳ, và sau đó là thông qua đường dây truyền tải điện của các nước thứ ba. 
(d) Nông nghiệp: Thúc đẩy cách tiếp cận chuỗi giá trị đối với các sản phẩm nông nghiệp an toàn và thân thiện với môi trường.

(e) Môi trường: Theo đuổi cách tiếp cận dịch vụ dựa trên hệ sinh thái đối với các cảnh quan trong Chương trình hợp tác GMS và RIF, và trong các khuôn khổ quốc tế.

(f) Du lịch: Nâng cao chất lượng và trải nghiệm của du khách, phát triển các điểm đến du lịch thứ cấp và phát triển nguồn nhân lực thông qua đào tạo, tập huấn dựa trên năng lực gắn với các tiêu chuẩn của Hiệp hội các Quốc gia Đông Nam Á.

(g) Tạo thuận lợi thương mại: Ủu tiên hiện đại hóa hải quan, quản lý biên giới có phối hợp và các phương pháp tiếp cận quản lý rủi ro đối với các tiêu chuẩn vệ sinh và kiểm dịch động thực vật.

(h) Phát triển nguồn nhân lực: Tập trung vào các vấn đề y tế của tiểu vùng và thu hút sự tham gia các đối tác phát triển khác trong các lĩnh vực lao động và di cư, phát triển xã hội, và đào tạo kỹ thuật và dạy nghề.

(i) Công nghệ thông tin và truyền thông: Thúc đẩy ứng dụng $\mathrm{CNTT}$, khắc phục các khoảng cách số, và thúc đẩy đổi mới CNTT.

(iii) Cải thiện các hệ thống và quy trình lập kế hoạch, xây dựng chương trình và giám sát. Các nội dung này bao gồm:

(a) xây dựng hướng dẫn cho các chiến lược và quy hoạch của ngành;

(b) xác định các mục tiêu định lượng và xây dựng khung giám sát kết quả;

(c) cải thiện phạm vi, nguyên tắc và quy trình của Khung Đầu tư vùng (RIF) để đảm bảo rằng các dự án GMS hỗ trợ các ưu tiên trong Kế hoạch hành động Hà Nội (HAP), đồng thời RIF đã bao gồm các dự án của chính phủ các quốc gia GMS, của $A D B$ và các đối tác phát triển; và

(d) theo đuổi một cách tiếp cận hệ thống hơn để huy động nguồn lực.

(iv) Cải tiến những sắp xếp thể chế và quan hệ đối tác. Chúng bao gồm:

(a) trao quyền cho các ban thư ký quốc gia chịu trách nhiệm cao hơn trong việc điều phối Chương trình hợp tác GMS;

(b) chỉ định một người dẫn dắt hoặc điều phối viên quốc gia cho các nhóm công tác theo lĩnh vực và cho phép những sắp xếp thể chế linh hoạt bên ngoài các cấu trúc chính thức (các nhóm chuyên gia lâm thời, mạng lưới làm việc, trao đổi ngang hàng); và

(c) tăng cường vai trò của Hội nghị Quan chức cao cấp với tư cách là cơ quan giám sát và điều phối cho các nhóm công tác.

Về quan hệ đối tác, khu vực tư nhân sẽ được khuyến khích tham gia các nhóm công tác theo lĩnh vực trong những sáng kiến cụ thể (ví dụ: đầu tư vào các chuỗi cung ứng, các đặc khu kinh tế và khu công nghiệp, các dự án đối tác công - tư về y tế và giáo dục); cũng như tăng cường hợp tác với chính quyền địa phương và cộng đồng địa phương.

Sẽ có một số yếu tố quyết định mức độ thành công của kết quả đạt được trong HAP. Những yếu tố này phải được khai thác, quản lý và lồng ghép một cách có ý thức trong quá trình triển khai HAP để chúng trở thành "nhân tố tạo thuận lợi" cho việc đạt được mục tiêu. Những "nhân tố tạo thuận lợi này” bao gồm: (i) tạo sự đồng vận với Hiệp hội các Quốc gia Đông Nam Á và các sáng kiến khu vực khác, (ii) thu hút sự tham gia hiệu quả của khu vực tư nhân, (iii) những cách tiếp cận mới trong thiết kế dự án và sắp xếp thể chế, (iv) các quy trình được hỗ trợ bởi công nghệ, và (v) kết nối và vận dụng tri thức. 


\section{GIỚI THIÊ़U}

Hai mươi lăm năm hợp tác trong khuôn khổ Chương trình Hợp tác kinh tế Tiểu vùng Mê-kông mở rộng (GMS) đã chứng kiến mối quan hệ hợp tác và đối tác ngày càng tiến triển giữa sáu quốc gia có chung dòng sông Mê-kông. Năm 1992, Cam-pu-chia, Cộng hòa Nhân dân Trung Hoa, Cộng hòa Dân chủ Nhân Lào, Mi-an-ma, Thái Lan và Việt Nam đã thành lập Chương trình Hợp tác kinh tế Tiểu vùng Mê-kông mở rộng (Chương trình GMS) và đề nghị Ngân hàng Phát triển Châu Á (ADB) hỗ trợ. Cho tới tận năm 2002, văn kiện Dựa trên thành công: Khung Chiến lược cho 10 năm tiếp theo của Chương trình Hợp tác kinh tế Tiểu vùng Mê-kông mở rộng (GMS SFI) đã được thông qua cho giai đoạn 2002-2012. Nó được tiếp nối bởi Khung chiến lược Chương trình Hợp tác kinh tế Tiểu vùng Mê-kông mở rộng giai đoạn 2012-2022 (GMS SF-II), với hoạt động Đánh giá giữa kỳ đã được tiến hành. Kế hoạch Hành động Hà Nội giai đoạn 2018-2022 (HAP) này phản ánh chương trình nghị sự hợp tác kinh tế GMS trong 5 năm còn lại của GMS SF-II, dựa trên những kết quả Đánh giá giữa kỳ, cũng như các mũi nhọn và ưu tiên hoạt động mới trong các chiến lược ngành. Nó được dựa trên nhũng thành tựu và bài học kinh nghiệm trong quá khứ, và vạch ra con đường phía trước để giải quyết những thách thức phát triển mới nổi thông qua hợp tác khu vực. 



\section{KHUNG CHIÎ́N LƯƠC TIỂU VỦNG MÊ-KÔNG MỞ RộNG GIAI ĐOẠN 2012-2022: TỔNG QUAN}

\section{A. Mục tiêu và định hướng chiến lược}

Khung chiến lược Chương trình Hợp tác kinh tế Tiểu vùng Mê-kông mở rộng giai đoạn 20122022 (GMS SF-II) được tán thành tại Hội nghị Bộ trưởng GMS lần thứ 17 trong tháng 8/2011 và được thông qua tại Hội nghị Thượng đỉnh GMS lần thứ tư diễn ra cùng năm. Đây là sự kế tiếp của văn kiện Dựa trên thành công: Khung chiến lược cho 10 năm tiếp theo của Chương trình Hợp tác kinh tế Tiểu vùng Mê-kông mở rộng (GMS SF-I), được đưa ra 10 năm sau khi Chương trình GMS được thành lập vào năm 1992. GMS SF-I đã đánh dấu tính phức tạp gia tăng của Chương trình GMS khi nó dấn thân vào những lĩnh vực nhiều thử thách hơn so với cách tiếp cận thận trọng trong 10 năm đầu của Chương trình GMS. Khi GMS SF-II được xây dựng, xung lực hội nhập kinh tế trong Hiệp hội các Quốc gia Đông Nam Á (ASEAN) đang ở đỉnh cao, tạo động lực cho các quốc gia GMS tăng tốc tự do hóa thương mại và đầu tư, và tận dụng các cơ hội trong một thị trường khu vực đang mở rộng. Kết nối thị trường là tối quan trọng khi các quốc gia GMS tập trung vào việc kết nối các nền kinh tế sôi động nhất Châu Á thông qua hợp tác khu vực.

GMS SF-II đã tái khẳng định sự phù hợp của tầm nhìn và các mục tiêu của GMS SF-I (xem Hộp) và cam kết dựa trên tiến bộ đạt được trong những năm trước để đưa hợp tác lên tầm cao mới. Để làm điều này, cách tiếp cận gồm sáu hướng sau đây sẽ được áp dụng:

(i) chú trọng nhiều hơn tới phần mềm để bổ sung cho trọng tâm tiếp tục vào phần cứng;

(ii) tính chọn lọc và ưu tiên cao hơn của các lĩnh vực trọng điểm trong từng ngành, bao gồm tập trung nhiều hơn vào các vấn đề có tính chất khu vực rõ ràng;

(iii) liên kết chặt chẽ hơn với chương trình nghị sự hội nhập khu vực rộng hơn, dẫn tới phân định rõ ràng hơn vấn đề khu vực nào sẽ thuộc phạm vi của Chương trình GMS và vấn đề nào tốt hơn nên để cho các tổ chức khu vực khác;

(iv) chú ý nhiều hơn tới mối liên kết giữa các lĩnh vực khác nhau;

\section{Hộp: Các mục tiêu của Khung chiến lược Tiểu vùng Mê-kông mở rộng}

- Gia tăng kết nối cơ sở hạ tầng

- Tạo thuận lợi cho thương mại và đầu tư xuyên biên giới, và du lịch

- Tăng cường sự tham gia của khu vực tư nhân và khả năng cạnh tranh

- Phát triển nguồn nhân lực

- Bảo vệ môi trường và thúc đẩy việc sử dụng bền vũng các nguồn tài nguyên thiên nhiên chung

Nguồn: ADB. 2002. Tài liệu Building on Success: A Strategic Framework for the Next Ten Years of the Greater Mekong Subregion Economic Cooperation Program. Manila. 
(v) tái cân bằng các nguồn lực mà không làm thay đổi trọng tâm lĩnh vực tổng thể của chương trình cũng như chú ý tới năng lực tổ chức và tiềm năng đạt được các kết quả thực tế giữa các lĩnh vực; và

(vi) nhấn mạnh hơn và có hiệu quả hơn tới việc giám sát kết quả và những cải tiến khác trong thực hiện chương trình. Điều này sẽ giúp nâng cao hiệu quả và tác động tổng thể của chương trình.

Một chiến lược cốt lõi mà GMS SF-II áp dụng là định hướng không gian, mở rộng khái niệm hành lang kinh tế vượt ra ngoài vai trò là tuyến đường vận chuyển và quá cảnh. Theo khái niệm mở rộng này, cách tiếp cận phát triển các hành lang kinh tế sẽ bao gồm (i) phát triển đô thị để mở rộng không gian hành lang cho việc kết nối các thị trường và khai thác các hiệu ứng tập trung; (ii) phát triển các đặc khu kinh tế và khu công nghiệp tại biên giới và dọc theo các hành lang như là phương tiện thu hút đầu tư tư nhân; và (iii) phát triển dịch vụ vận tải và hậu cần để tăng cường sự kết nối với các cửa ngõ thương mại và khiến các thị trường vận hành hiệu quả hơn. Chúng bao gồm các khoản đầu tư "thế hệ thứ hai" được hình dung trong GMS SF-II.

\section{B. Khung Đầu tư vùng}

Khung Đầu tư vùng (RIF) đã được xây dựng như một văn kiện đồng hành với GMS SF-II. RIF được dự kiến là khuôn khổ lập kế hoạch nhằm định hướng việc xây dựng và ưu tiên cho các chương trình và dự án giúp chuyển đổi các chiến lược ngành thành hành động. Quá trình xây dựng RIF được hỗ trợ bởi các đánh giá chặt chẽ về lĩnh vực và quốc gia, nhằm cung cấp cơ sở vững chắc để xác định những hoạt động can thiệp cần thiết hỗ trợ cho các mục tiêu của lĩnh vực. Quy trình RIF cho phép các quốc gia GMS rà soát và hoàn thiện danh mục dự án đề xuất trong Chương trình GMS một cách thường xuyên và liên tục theo yêu cầu đặt ra do tính chất phát triển năng động của tiểu vùng (Hình 1).

Việc đưa các dự án vào RIF được định hướng bởi các nguyên tắc sau:

(i) Các hoạt động đầu tư vào hành lang kinh tế phải dựa trên nhu cầu. Trước đây, GMS thực hiện cách tiếp cận dựa vào nguồn cung để phát triển hành lang kinh tế với quan niệm rằng việc xây dựng đường sá sẽ tự động biến thành hoạt động kinh tế. Bài học rút ra là điều này đã và sẽ không xảy ra.

(ii) Tính kết nối với bên ngoài tại biên giới phải được cân bằng với khả năng kết nối trong nước. Dù kết nối đường bộ xuyên biên giới là quan trọng đối với thương mại, song kết nối trong nước cung cấp sự gắn kết quan trọng dọc theo chuỗi cung ứng và do vậy có thể mang lại lợi ích tương đương.

(iii) Cần thúc đẩy một cách tiếp cận đa ngành để có được sự đồng vận lớn hơn. Điều này không chỉ nói tới đầu tư đa ngành trong một bối cảnh không gian (ví dụ: kết hợp các dự án giao thông, điện, nước và vệ sinh trong phát triển đô thị), mà còn là sự pha trộn giữa phần cứng và phần mềm hoặc các vấn đề chính sách (ví dụ khung pháp lý cho thương mại năng lượng cần phải đi cùng với việc kết nối các lưới điện), cũng như các cơ chế thể chế để phối hợp hiệu quả.

(iv) Nên vận dụng ưu tiên không gian dựa trên các tiêu chí phù hợp. Xét tới các nguồn lực đầu tư hạn chế, ưu tiên không gian và xác định trình tự thời gian bên trong và giữa 
các hành lang kinh tế nên được sử dụng như một phương thức để tối ưu hóa đầu tư và mang lại tác động có ý nghĩa. Uu tiên không gian có thể được định hướng bởi các ưu tiên quốc gia, tác động khu vực, chi phí và lợi ích kinh tế.

Hình 1: Các quy trình hoạt động trong Khung Đầu tư vùng của Tiểu vùng Mê-kông mở rộng

\section{Khung chiến lược GMS giai đoạn 2012-2022}

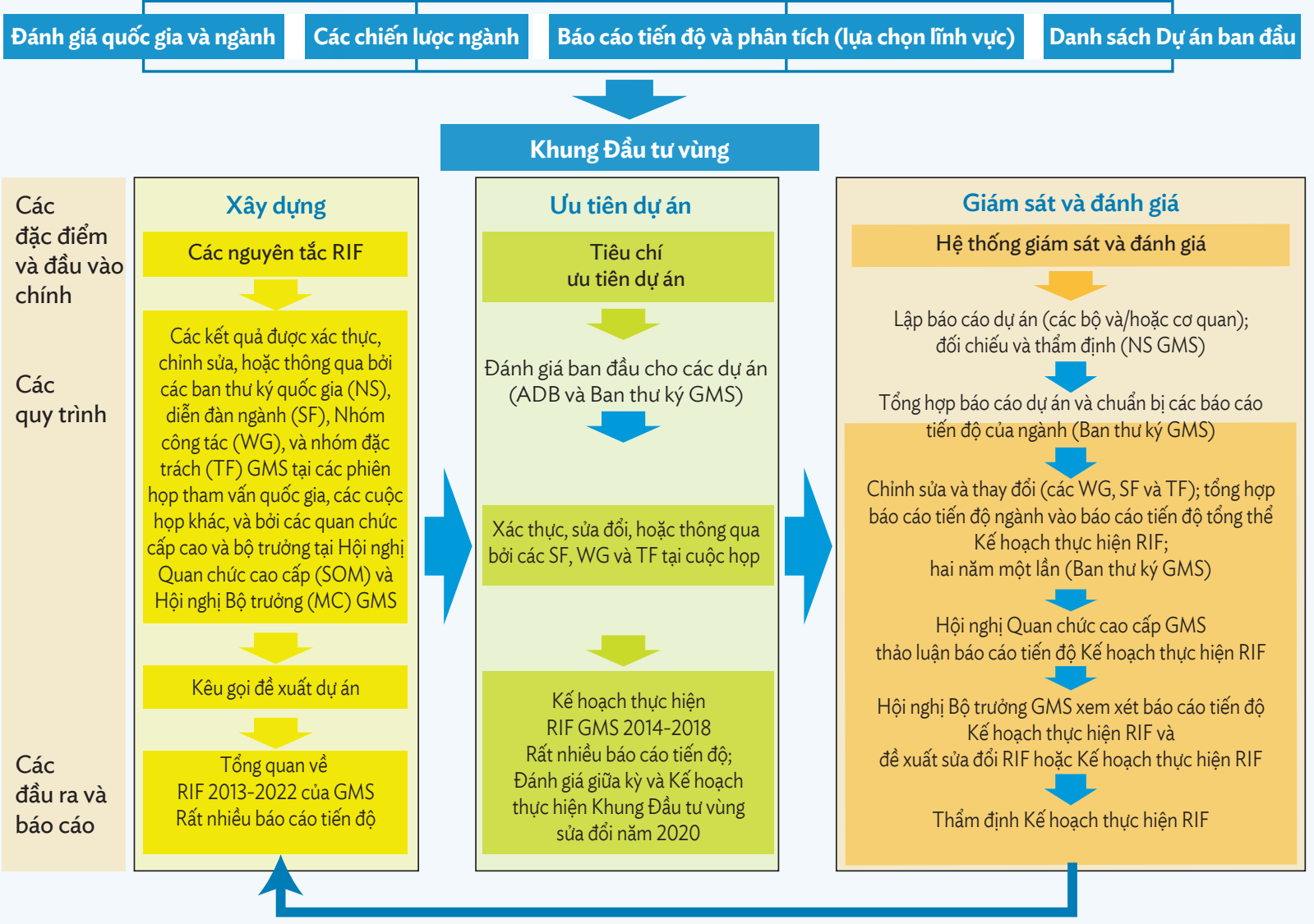

$\mathrm{ADB}=$ Ngân hàng Phát triển Châu Á, GMS = Tiểu vùng Mê-kông mở rộng, IP = Kế hoạch thực hiện, $M \& E$ = giám sát và

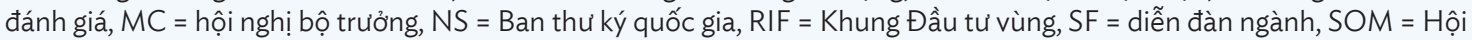
nghị quan chức cấp cao, TF = nhóm đặc trách, WG = nhóm công tác.

Nguồn: Ngân hàng Phát triển Châu Á.

Khung Đầu tư vùng lần thứ nhất cho giai đoạn 2013-2022 bao gồm một danh sách dài với hơn 200 dự án đầu tư và hỗ trợ kỹ thuật để hỗ trợ các chiến lược của GMS SF-II. Danh sách này sau đó đã được chuyển đổi thành một danh mục dự án đề xuất cho trung hạn, được gọi là Kế hoạch thực hiện RIF (RIF-IP) cho giai đoạn 2014-2018, và sau đó được mở rộng tới năm 2020. RIF-IP là một danh sách ngắn các dự án dựa trên danh sách dài của RIF giai đoạn 2013-2022, được ưu tiên lựa chọn dựa trên một tập hợp các tiêu chí và hướng dẫn. Đánh giá giữa kỳ RIF-IP đã được thực hiện vào giữa năm 2016, với kết quả là một danh sách cập nhật các dự án ưu tiên tới năm 2020 đã được Hội nghị Bộ trưởng GMS lần thứ 21 thông qua vào tháng 12/2016. Một đợt cập nhật khác sẽ mở rộng phạm vi tới năm 2022, trùng với năm kết thúc của GMS SF-II. 



\section{III. ĐÁNH GIÁ GIỮA KỲ KHUNG CHIẾN LƯợC TIẾU VÙNG MÊ-KÔNG MỚ RộNG GIAI ĐOẠN 2012-2022}

\section{A. Mục tiêu}

Hội nghị Bộ trưởng GMS lần thứ 21 trong tháng 12/2016 đã thông qua việc đánh giá giữa kỳ Khung chiến lược Chương trình hợp tác kinh tế Tiểu vùng Mê-kông mở rộng giai đoạn 20122022 (GMS SF-II) với các mục tiêu sau: (i) đánh giá tiến triển đạt được cho tới nay và những công việc còn lại cần thực hiện; (ii) xác định tính hiệu quả và tính đáp ứng tiếp tục đối với các nhu cầu và ưu tiên phát triển của các quốc gia GMS; và (iii) xác định những mũi nhọn mới nổi ở cấp độ chương trình và lĩnh vực. Kết quả đánh giá giữa kỳ sẽ là cơ sở cho nhũng định hướng và trọng tâm hoạt động trong 5 năm còn lại của GMS SF-II và được đưa vào trong Kế hoạch hành động Hà Nội (HAP) giai đoạn 2018-2022.

Đánh giá giữa kỳ tập trung vào năm lĩnh vực đánh giá: (i) tính phù hợp liên tục của các chiến lược GMS SF-II trong việc hỗ trợ các ưu tiên quốc gia; (ii) tính nhất quán (hoặc phù hợp) giữa chiến lược tổng thể, ngành hoặc chương trình và các dự án; (iii) hiệu quả thực thi trong giai đoạn 20122016; (iv) các quy trình lập kế hoạch và xây dựng chương trình; và (v) hiệu quả thể chế.

\section{B. Những phát hiện chính}

\section{Sự phù hợp của Khung chiến lược Chương trình Hợp tác kinh tế Tiểu vùng Mê-kông mở rộng giai đoạn 2012-2022 (GMS SF-II) với Chương trình nghị sự phát triển quốc gia}

Mặc dù các chiến lược và kế hoạch phát triển quốc gia đã có sự thay đổi về ưu tiên và chiến lược kể từ khi GMS SF-II được xây dựng vào năm 2012, vẫn có sự hội tụ chung giữa các ưu tiên quốc gia và các mũi nhọn chiến lược GMS, mang đến vai trò cho tất cả các lĩnh vực. Phát triển hành lang kinh tế và giao thông được các quốc gia GMS xem là lĩnh vực hợp tác có lợi nhất, khi họ nỗ lực tiến hành công nghiệp hóa và đa dạng hóa nền kinh tế và hội nhập với các chuỗi giá trị khu vực. Các lĩnh vực quan trọng khác là du lịch, nông nghiệp và năng lượng. Các quốc gia GMS đánh giá tính phù hợp của Chương trình GMS ở mức trung bình đến cao.

\section{Sự nhất quán giữa chiến lược chung của Khung chiến lược Chương trình} Hợp tác kinh tế Tiểu vùng Mê-kông mở rộng giai đoạn 2012-2022 (GMS SF-II), các chiến lược ngành và các dự án trong Khung Đầu tư vùng Nhìn chung, các chiến lược trong GMS SF-II và chiến lược ngành là thống nhất, có nghĩa là chúng được đặt trong mối quan hệ với nhau để đạt được cùng các mục tiêu chung. Các dự án trong Khung Đầu tư vùng (RIF) phần lớn hỗ trợ ưu tiên của ngành, nhưng một số ưu tiên vẫn 
chưa được đáp ứng. Các ưu tiên của ngành được cả các dự án đầu tư và hỗ trợ kỹ thuật trong RIF hỗ trợ mạnh mẽ bao gồm:

(i) Giao thông: các tuyến đường bên trong các hành lang kinh tế và liên kết với các cửa ngõ;

(ii) Phát triển đô thị: các khu kinh tế cửa khẩu, mở rộng hành lang kinh tế và các liên kết đa ngành;

(iii) Năng lượng: tích hợp và kết nối mạng lưới điện khu vực;

(iv) Nông nghiệp: các trung tâm kinh doanh nông nghiệp tại các hành lang và chuỗi cung ứng nông nghiệp;

(v) Du lịch: cơ sở hạ tầng liên quan đến du lịch trong các hành lang kinh tế;

(vi) Tạo thuận lợi thương mại: áp dụng các biện pháp vệ sinh và kiểm dịch động thực vật (SPS) cho các quốc gia GMS chọn lọc; và

(vii) Phát triển nguồn nhân lực y tế: kiểm soát bệnh truyền nhiễm.

Các lĩnh vực ưu tiên của ngành mà không có hoặc chỉ có rất ít dự án là vận tải đa phương thức, đặc biệt là các tuyến kết nối đường sắt; hậu cần phục vụ thương mại; năng lượng tái tạo và hiệu quả năng lượng; trao đổi các thỏa thuận về quyền vận tải; và phối hợp quản lý biên giới.

\section{Hiệu quả thực thi}

Việc đánh giá hiệu quả thực thi được dựa trên (i) thông tin dự án trong RIF (dự án đã hoàn thành; dự án bắt đầu thực hiện, bao gồm các nghiên cứu khả thi; và dự án có huy động vốn); và (ii) các đánh giá ngành (bao gồm đánh giá giữa kỳ của ngành).

Hiệu quả thực hiện các dự án trong RIF cho thấy một bức tranh hỗn hợp. Đánh giá giữa kỳ RIFIP chỉ ra rằng 56\% các dự án nêu trong RIF giai đoạn 2014-2018 đã bảo đảm nguồn tài chính, chiếm $85 \%$ tổng chi phí ước tính. Trong số các dự án đầu tư, 30\% đã bắt đầu triển khai, trong đó có 14 dự án thuộc lĩnh vực giao thông. Trong số các nghiên cứu khả thi bắt đầu được tiến hành cho 18 dự án khác (30\%), 14 nghiên cứu cũng thuộc lĩnh vực giao thông. Về mặt thực hiện, có thể còn quá sớm để đánh giá hiệu quả của các dự án RIF do cần thời gian để chuẩn bị các dự án đầu tư và giai đoạn xử lý kéo dài trước khi dự án được triển khai.

Các đánh giá ngành cung cấp một bức tranh toàn diện hơn về hiệu quả thực hiện của từng lĩnh vực liên quan đến các mục tiêu và ưu tiên của GMS SF-II, như được nêu bật dưới đây.

Giao thông. Việc triển khai tất cả 36 dự án đầu tư giao thông ưu tiên trong khuôn khổ Chiến lược ngành giao thông 2015 về cơ bản đã hoàn thành hoặc đang diễn ra. Đặc biệt, các dự án đường bộ đã ghi nhận hiệu quả triển khai tốt, bao gồm các dự án giao thông thuộc RIF-IP cho giai đoạn 2014-2018. Gần 10.000 km đường đã được xây dựng với sự hỗ trợ tài chính của ADB ở các quốc gia GMS từ năm 2002 đến 2016. Tuy nhiên, tiến độ trong các tiểu ngành đường sắt và đường thủy nội địa còn trì trệ. Nỗ lực thiết lập một thị trường mở cho các dịch vụ vận tải, cải thiện hiệu suất giao thông và khuyến khích sử dụng vận tải đa phương thức cũng có ít tiến triển. Tác động phát triển của các dự án đường bộ trong GMS còn khiêm tốn trong bối cảnh chậm triển khai Hiệp định Tạo thuận lợi vận chuyển xuyên biên giới (CBTA) do tính chất phức tạp của những cải cách chính sách và pháp lý theo quy định.' Tuy nhiên, những tiến triển dần dần vẫn tiếp tục diễn ra. Trong năm 2015, cơ chế kiểm tra "một cửa, một lần dừng" (SSI) đã được triển khai ở biên giới Lao Bảo - Dansavanh và tại cửa khẩu Savannakhet - Mukdahan. Các thủ tục kiểm tra một cửa

ADB. 2014. Tài liệu Assessing Impact in the GMS: An Analysis of Regional Cooperation Projects. Manila. 
tương tự đang được lên kế hoạch áp dụng tại các cửa khẩu biên giới khác trong GMS. Gần đây, các quốc gia GMS đã bắt đầu triển khai "thu hoạch sớm" Hiệp định CBTA, theo đó, có tới 500 giấy phép vận chuyển đường bộ trong GMS sẽ được cấp bởi tất cả các quốc gia trong năm 2017, ngoại trừ Mi-an-ma với dự kiến sẽ thực hiện trong năm 2019.

Phát triển hành lang kinh tế. Đã có những tiến bộ đáng kể trong việc phát triển ba hành lang kinh tế ưu tiên của GMS: Hành lang kinh tế Đông - Tây, Hành lang kinh tế Bắc - Nam và Hành lang kinh tế phía Nam. Chiến lược và các kế hoạch hành động (SAP) cho ba hành lang này đã được thực hiện khoảng $85 \%{ }^{2}$ Các dự án đường bộ trong những hành lang này đã được hoàn thành hoặc sắp hoàn thành, trong khi các dự án cơ sở hạ tầng du lịch đang tiến triển tốt. Năm 2016, bộ trưởng của các quốc gia GMS đã phê duyệt những thay đổi trong định dạng các hành lang kinh tế GMS để bảo đảm có sự gắn kết chặt chẽ giữa các tuyến hành lang và dòng chảy thương mại; các thủ đô của các quốc gia GMS và các trung tâm đô thị lớn được kết nối với nhau; và các hành lang được liên kết với các cửa ngõ hàng hải. Một tiểu hành lang mới đã được bổ sung vào Hành lang kinh tế Bắc - Nam, nối từ Mandalay tới Tamu ở biên giới Ấn Độ nhằm thúc đẩy sự gắn kết với khu vực Nam Á. Đây là một phần của Dự án đường cao tốc ba bên Ấn Độ-Mianma-Thái Lan, nối Ấn Độ với Thái Lan qua Mi-an-ma.

Phát triển đô thị, khu kinh tế cửa khẩu và các dự án không gian đa ngành khác. Phát triển đô thị là một lĩnh vực hợp tác mới, được dự kiến đóng vai trò trung tâm trong chiến lược mở rộng và làm sâu sắc thêm quy mô của các hành lang kinh tế và thúc đẩy đầu tư đa ngành. Cách tiếp cận phát triển đô thị tiểu vùng được coi là một phương tiện để thúc đẩy dòng chảy hàng hóa giữa các đô thị trong khu vực, thúc đẩy hội nhập giữa thành thị - nông thôn, và tạo hiệu ứng tích tụ bằng cách tăng quy mô của các khu vực có tiềm năng kinh tế nhằm tạo ra hiệu quả kinh tế nhờ quy mô, thu hút đầu tư và kích thích đổi mới. Cho tới nay, các sáng kiến phát triển đô thị tập trung vào các thành phố và đô thị hành lang nằm dọc theo các hành lang kinh tế GMS, trong đó hoạt động đầu tư chủ yếu là cho cơ sở hạ tầng môi trường như thoát nước, vệ sinh, quản lý chất thải rắn và các khu vực công cộng. Theo Khung chiến lược phát triển đô thị giai đoạn 2015-2022, sẽ xác định các trung tâm đô thị ưu tiên khác cũng như những cửa khẩu ưu tiên dọc theo các hành lang kinh tế GMS để phục vụ việc xây dựng quy hoạch không gian của các khu vực này trong giai đoạn sau.

Năng lượng. Những tiến triển trong việc thiết lập một lưới điện khu vực tích hợp và thị trường điện khu vực tiếp tục bị hạn chế bởi những thách thức về kỹ thuật, quy định và thể chế. Các quốc gia GMS đã đạt tới giai đoạn 1 gồm các liên kết mạng lưới điện song phương, và đang chuyển sang giai đoạn 2 với việc liên kết lưới điện với lưới điện, dù tiến triển còn ít. Một số hạn chế cần được giải quyết để tăng tốc giai đoạn 2, bao gồm đưa Trung tâm điều phối điện khu vực (RPCC) vào hoạt động; cơ quan này sẽ đóng vai trò then chốt trong việc thúc đẩy các vấn đề về kỹ thuật, giá cả và pháp lý. Các lĩnh vực hợp tác năng lượng khác được nêu trong Chiến lược năng lượng không có nhiều triển vọng xét về mặt hợp tác trong GMS. Chỉ có rất ít cơ hội hợp tác trong GMS trong lĩnh vực dầu khí, do các quốc gia GMS đã tham gia các lĩnh vực này trong khuôn khổ ASEAN. Hiệu quả năng lượng và quản lý phía cầu đang được xử lý hiệu quả hơn ở cấp quốc gia thông qua việc thực thi các quy định về kiểm toán, dán nhãn và tiêu chuẩn. Tiến triển trong năng lượng tái tạo là rất khiêm tốn, với chỉ một số ít các dự án năng lượng tái tạo ngoài mạng lưới được thực hiện cho tới nay.

2 ADB. 2017. Tài liệu GMS Giao thông Sector Strategy 2018-2030. Manila. 
Nông nghiệp. Chiến lược hợp tác GMS trong nông nghiệp hiện tại - Chương trình hỗ trợ nông nghiệp then chốt giai đoạn II 2011-2015 - đã được mở rộng tới năm 2020. Chiến lược này tập trung vào an toàn thực phẩm và hiện đại hóa thương mại nông nghiệp; nông nghiệp thân thiện với môi trường; và quản lý năng lượng sinh học và nhiên liệu sinh khối. Trong các lĩnh vực trọng tâm này, đã có những tiến bộ đáng ghi nhận trong các khía cạnh giảm thiểu hạn hán, sử dụng sinh khối cho năng lượng sinh học, thúc đẩy các thông lệ canh tác nông nghiệp thân thiện với môi trường và nhạy cảm về giới, và áp dụng cách tiếp cận chuỗi giá trị đối với thực phẩm an toàn. Các dự án đầu tư cũng được chuẩn bị để hỗ trợ cơ sở hạ tầng xuyên biên giới nhằm thúc đẩy thương mại nông nghiệp; các chuỗi giá trị kinh doanh nông nghiệp thông qua các tuyến đường tiếp cận thị trường; cơ sở hạ tầng kho bãi và hậu cần; cũng như các hệ thống chứng nhận và truy xuất nguồn gốc dựa trên công nghệ thông tin. Cách tiếp cận chuỗi giá trị đối với thực phẩm an toàn mới nổi lên như một lĩnh vực trọng tâm trong 5 năm tiếp theo. Chiến lược thúc đẩy các chuỗi giá trị nông nghiệp an toàn và thân thiện với môi trường trong Tiểu vùng Mê-kông mở rộng và Kế hoạch hành động Siêm Riệp giai đoạn 2018-2022 sẽ mở rộng hơn nữa quan hệ hợp tác trong an toàn thực phẩm và hiện đại hóa thương mại nông nghiệp bằng cách kết nối các chuỗi giá trị sản phẩm nông nghiệp an toàn và thân thiện với môi trường thông qua cơ sở hạ tầng, chia sẻ tri thức, tiếp thị và phát triển thể chế.

Môi trường. Trong Chương trình Môi trường then chốt (giai đoạn 2012-2016, mở rộng tới 2017), hay còn gọi là CEP 2, đã có nhũng kết quả quan trọng được tạo ra trong lĩnh vực lập kế hoạch và bao đảm an toàn môi trường; giám sát cảnh quan đa dạng sinh học; thích ứng biến đổi khí hậu trong các hành lang đa dạng sinh học; và tăng cường hợp tác với các nhóm công tác GMS trong việc ứng dụng các công cụ và mô hình, xây dựng chiến lược, nâng cao nhận thức, chia sẻ tri thức, thu hút sự tham gia của các bên liên quan, phân tích thực trạng ngành và quốc gia, và thiết kế dự án. Việc gia hạn CEP 2 tới năm 2017 đã cho phép chương trình định hướng lại các hoạt động hỗ trợ của mình từ các nhiệm vụ ở cấp độ cộng đồng sang nhưng can thiệp ở cấp độ chương trình có ảnh hưởng ở phạm vi quốc gia và xuyên biên giới. Việc tái định hướng chiến lược này đã mở ra những lĩnh vực hoạt động mới. CEP đã gia tăng hỗ trợ cho các công cụ và cách tiếp cận quy hoạch đa ngành để cải thiện hiệu quả môi trường của các dự án đầu tư trong RIF, bao gồm các tiêu chí môi trường cho quy hoạch không gian cơ sở hạ tầng ở các vùng biên giới của ba hành lang kinh tế ưu tiên trong GMS. CEP cũng tiếp tục tìm kiếm cơ hội để hỗ trợ các nghiên cứu thực trạng ngành và thiết kế dự án nhằm lồng ghép môi trường trong các lĩnh vực năng lượng, giao thông và nông nghiệp.

Tạo thuận lợi thương mại. Các hoạt động tạo thuận lợi thương mại trong khuôn khổ Kế hoạch Hành động Tạo thuận lợi thương mại và giao thông giai đoạn 2015-2017 đã đạt được một số thành tựu ban đầu: (i) thực thi các tiêu chuẩn trong Công ước Kyoto sửa đổi về cải cách lĩnh vực hải quan, cùng với các hệ thống hỗ trợ dựa trên công nghệ thông tin để đơn giản hóa và chuẩn hóa các thủ tục hải quan; (ii) phối hợp quản lý biên giới với việc ứng dụng kiểm soát rủi ro ban đầu; (iii) bắt đầu áp dụng thủ tục kiểm tra một cửa hoặc một điểm dừng đối với luồng hàng hóa tại các cửa khẩu nhất định; và (iv) các biện pháp tăng cường tổ chức thực thi vệ sinh và kiểm dịch động thực vật (SPS) đối với thương mại GSM được thực hiện như một phần của các dự án đầu tư tại Cam-pu-chia và Cộng hòa dân chủ nhân dân Lào. Xét tới tính chất phức tạp của các cải cách pháp lý và sự phối hợp thể chế cần thiết để thực hiện những biện pháp tạo thuận lợi thương mại, các cơ chế phối hợp thể chế hiệu quả ở cả cấp độ quốc gia và khu vực sẽ là yếu tố then chốt quyết định tiến độ và thành công của việc thực thi các biện pháp tạo thuận lợi thương mại. Một Nhóm công tác tạo thuận lợi thương mại mới sẽ là chìa khóa để xây dựng chương trình nghị sự tạo thuận lợi thương mại sau năm 2017. 
Du lịch. Chiến lược ngành du lịch giai đoạn 2006-2015 (TSS I) có mục tiêu là phát triển Tiểu vùng Mê-kông như một điểm đến du lịch đơn nhất và cung cấp một loạt các sản phẩm du lịch chất lượng, giúp phân phối lợi ích từ du lịch rộng rãi hơn và góp phần cho công cuộc giảm nghèo, thúc đẩy bình đẳng giới và phát triển bền vững. Được định hướng bởi chiến lược này trong 10 năm qua, GMS đã đạt được những cải tiến đáng kể trong tiếp thị điểm đến, cơ sở hạ tầng du lịch tập trung vào việc liên kết các khu vực nông thôn và thành thị, bảo vệ các điểm tham quan di sản và tạo thuận lợi cho du lịch lũ hành. Trong năm 2015, tî lệ du khách từ các thị trường du lịch đường dài đến thăm GMS đã đạt múc kỷ lục là $30 \%$ và tỷ lệ các chuyến đi qua nhiều quốc gia trong GMS đạt 3,4 triệu. Xây dựng năng lực cho các bên liên quan trong ngành du lịch trong chính phủ và khu vực tư nhân đã được thực hiện như một phần của chiến lược tăng cường chuỗi cung ứng để đáp ứng nhu cầu của ngành. Khung thể chế cho ngành du lịch - Văn phòng điều phối du lịch Mê-kông - đã được củng cố để chuẩn bị cho việc trở thành một tổ chức liên chính phủ. Một kế hoạch tiếp thị toàn diện cho giai đoạn 2015-2020 đã được xây dựng với sự tham gia của tất cả các bên liên quan.

Phát triển nguồn nhân lực. Khung chiến lược và Kế hoạch Hành động Phát triển nguồn nhân lực giai đoạn 2013-2017 (SFAP) nhấn mạnh sự cần thiết phải tập trung vào các hoạt động thực sự mang tính khu vực trong bốn tiểu ngành phát triển nguồn nhân lực (HRD), gồm y tế, giáo dục, di cư lao động và phát triển xã hội. Kinh nghiệm trong việc triển khai SFAP chỉ ra rằng ngoài tiểu ngành y tế, phạm vi cho cách tiếp cận tiểu vùng GMS đối với phát triển nguồn nhân lực là hạn chế hơn nhiều so với cách tiếp cận vùng của ASEAN (và cơ chế ASEAN + 1 với sự tham gia của Cộng hòa Nhân dân Trung Hoa [PRC]) trong lĩnh vực phát triển nhân lực. Trong tiểu ngành y tế, đã có những tiến bộ đáng kể trong việc kiểm soát bệnh truyền nhiễm ở cả cấp quốc gia và tiểu vùng. Các dự án trong tiểu ngành giáo dục tập trung vào giáo dục và đào tạo kỹ thuật và dạy nghề, chủ yếu bao gồm các hoạt động hỗ trợ ở cấp quốc gia, đáp ứng các đặc trưng và nhu cầu riêng biệt của thị trường lao động trong nước. Hợp tác GMS trong giáo dục đại học đang diễn ra trong khuôn khổ ASEAN thông qua các cách tiếp cận khu vực trong việc chuyển giao tín chỉ học thuật, bảo đảm chất lượng và công nhận lẫn nhau. Không có tiến triển trong lĩnh vực di cư lao động, và chỉ có các hoạt động xây dựng năng lực phòng chống HIV/AIDS diễn ra như một phần của việc giảm thiểu chi phí xã hội cho phát triển hành lang kinh tế. Tuy nhiên, các quốc gia GMS tiếp tục được hưởng lợi từ một sáng kiến xây dựng năng lực toàn diện tiếp nối Kế hoạch Phnom Penh về Quản lý phát triển trong GMS. Thông qua Khu vực tăng trưởng Đông ASEAN gồm Brunây-Inđônêxia-Malaixia-Philippin, Tam giác tăng trưởng Inđônêxia-Malaixia-Thái Lan và Chương trình xây dựng năng lực kết nối Tiểu vùng Mê-kông mở rộng (B-I-G), năng lực của các quan chức chính phủ từ ba tiểu vùng đang được cải thiện để xây dựng và thực hiện các chính sách, chương trình và dự án hỗ trợ về cơ sở vật chất, thể chế, và kết nối giữa người với người. Chương trình $B-I-G$ cũng đã tạo cơ hội cho các quan chức từ ba tiểu vùng tương tác và học hỏi lẫn nhau.

Công nghệ thông tin và truyền thông. Mục tiêu dài hạn của hợp tác tiểu vùng trong lĩnh vực viễn thông là cải thiện các liên kết và ứng dụng viễn thông giữa các quốc gia GMS như một phương tiện để tăng cường khả năng cạnh tranh của tiểu vùng. Để đạt được mục tiêu này, Khung chiến lược về phát triển công nghệ thông tin và truyền thông trong $\mathrm{GMS}$ đã được thông qua vào tháng 6/2011, nhưng chưa được cập nhật như dự kiến trong GMS SF-II. Một biên bản ghi nhớ về Mạng lưới siêu xa lộ thông tin cũng đã được ký vào tháng 12/2011 liên quan đến việc đồng xây dựng một nền tảng băng thông rộng kết nối sáu quốc gia và cung cấp các thông số cho việc tiếp cận phổ cập các ứng dụng CNTT. Tuy nhiên, sự chú trọng gần đây tới hợp tác thương mại điện tử, với 
việc thành lập Diễn đàn hợp tác thương mại điện tử GMS vào tháng 6/2015, đã mang lại một số thành tựu cụ thể. Với mục tiêu thúc đẩy các doanh nghiệp thương mại điện tử xuyên biên giới, Diễn đàn thương mại điện tử đã dẫn đến việc thành lập Liên minh doanh nghiệp GMS, việc phát triển các ứng dụng trên điện thoại di động về thông tin hậu cần GMS, và xây dựng một trang web bao gồm các nền tảng ươm tạo, đào tạo tập huấn, và giao dịch thương mại. Các thỏa thuận hợp tác chiến lược đã được ký kết bởi bốn doanh nghiệp thương mại điện tử đến từ Cộng hòa nhân dân Trung Hoa, Mi-an-ma và Thái Lan. Trung tâm phát triển kinh tế và thương mại Tiểu vùng Mê-kông - Lan Thương (Vân Nam, Cộng hòa nhân dân Trung Hoa) đóng vai trò là đầu mối liên hệ của diễn đàn này trong ba năm đầu tiên cho đến năm 2018.

\section{Các quy trình lập kế hoạch và xây dựng chương trình}

Quy trình lập kế hoạch. Mặc dù cơ quan đầu mối của chính phủ trong hợp tác GMS ở hầu hết các quốc gia GMS (trừ Trung Quốc) là Bộ Kế hoạch, song Chương trình GMS không có một quy trình lập kế hoạch vùng được xác định rõ với các nhiệm vụ thể chế rõ ràng. Về mặt lý tưởng, chu trình lập kế hoạch nên bắt đầu bằng việc hình thành tầm nhìn và sứ mệnh; tiếp đó là thiết lập các mục tiêu có thể đo lường được; xây dựng các chiến lược để đạt được mục tiêu, cả ở cấp độ chương trình và lĩnh vực; xác định các hoạt động hỗ trợ (chương trình và dự án) cần thiết để biến các chiến lược này thành hành động; giám sát tiến độ thực hiện; và đánh giá kết quả. Chu kỳ này được đặt trong một khung thời gian hoặc lịch trình thống nhất. Chương trình GMS không có một chu trình lập kế hoạch được xác định rõ như vậy. GMS SF-II vẫn duy trì tầm nhìn và về cơ bản là hoàn thiện thêm các mũi nhọn chiến lược của GMS SF-I. Cả GMS SF I và II đều không có các mục tiêu rõ ràng và có thể đo lường được. Điều này cũng đúng với một số ngành, trong đó các mục tiêu nêu ra hầu hết là các thuật ngữ định tính và không có khung giám sát kết quả nào được xây dựng hoặc triển khai.

Xây dựng chương trình và ưu tiên. Trong đợt đánh giá giữa kỳ, một số nhận xét liên quan đến các quy trình và phương pháp luận của RIF đã được các quốc gia GMS nêu ra:

(i) các tiêu chí ưu tiên của dự án, bao gồm "sự sẵn có nguồn tài chính", đã làm sai lệch thành phần theo lĩnh vực của các dự án RIF và hạn chế tính hữu dụng của RIF như một công cụ tiếp thị để thu hút nguồn tài trợ từ các đối tác phát triển và khu vực tư nhân;

(ii) các dự án đang được triển khai khi bắt đầu GMS SF-II nên được đưa vào RIF, với cân nhắc rằng các dự án này đang được thực thi để hỗ trợ các chiến lược ngành được thực hiện từ GMS SF-I sang tới GMS SF-II;

(iii) RIF có xu hướng tập trung vào $A D B$, với rất nhiều lĩnh vực hầu hết (nếu không phải là chỉ) bao gồm các dự án do $A D B$ hỗ trợ, và loại trừ các dự án do các chính phủ GMS và các đối tác phát triển khác tài trợ; và

(iv) có khả năng "kiểm đếm thiếu" do không có sự phân biệt giữa các chương trình đa thành phần và các dự án đơn lẻ, cả hai đều được tính một lần.

Khung Đầu tư vùng (RIF) 2022 gần đây đã giải quyết hầu hết nhũng vấn đề được nêu ra này và những cải tiến tiếp theo sẽ được thực hiện như một phần của hoạt động cập nhật thường xuyên.

Giám sát và đánh giá. Mặc dù GMS SF-II có nhấn mạnh tới giám sát và đánh giá kết quả, song việc này vẫn chưa được triển khai đầy đủ. Ngành du lịch và nông nghiệp đã xây dựng được hệ thống giám sát và đánh giá tương đối tốt. Các ngành khác chưa xây dựng khung kết quả; một số ngành đã có khung kết quả trong tài liệu chiến lược của mình, nhưng chưa được triển khai trong 
quá trình thực hiện. Việc thiếu thông tin chính xác về kết quả dẫn tới không thể lập kế hoạch dựa trên bằng chứng thực tế và hạn chế cơ hội có được sự hiểu biết để cải thiện các sáng kiến trong tương lai.

\section{Hiệu quả thể chế}

Khung thể chế tổng thể. Trong 25 năm qua, Chương trình GMS đã trở thành một trong những chương trình hợp tác tiểu vùng ổn định và thành công nhất ở Đông Nam Á. Điều này phần lớn là nhờ cách tiếp cận thực dụng và được định hướng bởi dự án của Chương trình, giúp tạo ra những kết quả cụ thể trên thực tế. Nghiên cứu về Tăng cường khung thể chế GMS3 đã kết luận rằng khung thể chế tổng thể của Chương trình GMS - với cấu trúc đa tầng gồm các hội nghị thượng đỉnh, bộ trưởng, quan chức cao cấp và nhóm công tác - đã phát huy hiệu quả. Lần đầu tiên vào năm 2017, Diễn đàn các hành lang kinh tế (ECF) đã được tổ chức bên lề Hội nghị Bộ trưởng GMS để có sự phối hợp tốt hơn ở cấp độ lập chính sách của các cách tiếp cận theo ngành và không gian. Vai trò của $A D B$ trên cương vị nhà tài trợ chính và ban thư ký là yếu tố then chốt trong việc xây dựng và thực thi các can thiệp chiến lược thông qua những dự án đầu tư và hỗ trợ kỹ thuật, thúc đẩy các nguồn lực từ chính phủ và các đối tác phát triển khác, và duy trì xung lực hợp tác.

Nhóm công tác ngành. Những điều chỉnh ở cấp độ nhóm công tác được nhận thấy là cần thiết để đáp ứng các ưu tiên và diễn biến mới trong môi trường của Chương trình GMS. Hiệp hội đường sắt Tiểu vùng Mê-kông mở rộng được thành lập vào năm 2014 với vai trò một cơ quan chuyên môn, tách bạch khỏi Diễn đàn Giao thông tiểu vùng, với mục tiêu đảm bảo tất cả các quốc gia GMS được kết nối với một mạng lưới đường sắt vào năm 2020, thúc đẩy phát triển mạng lưới đường sắt liền mạch, và xây dựng các thể chế và quy trình thủ tục cần thiết để tích hợp đường sắt quốc gia. Nhóm đặc trách về phát triển đô thị được nâng cấp thành Nhóm công tác phát triển đô thị chính thức vào năm 2016, với nhiệm vụ hoàn thiện chi tiết Khung chiến lược phát triển đô thị giai đoạn 2015-2022 trên khía cạnh xác định các trung tâm đô thị và khu vực biên giới cần ưu tiên phát triển.

Năm 2017, các thỏa thuận thể chế về hợp tác phát triển nguồn nhân lực (HRD) đã được hợp lý hóa, với việc thành lập một Nhóm công tác về Hợp tác y tế riêng rẽ để tạo thuận lợi cho các sáng kiến y tế của tiểu vùng, và khám phá khả năng hợp tác về lao động và di cư cũng như giáo dục và đào tạo kỹ thuật và dạy nghề với Tổ chức Di cư quốc tế và Tổ chức Hợp tác phát triển Đức, vốn có các chương trình chuyên biệt trong những lĩnh vực này. Các hành động này đã tái cơ cấu Nhóm công tác phát triển nguồn nhân lực một cách hiệu quả. Đang tiếp tục có những nỗ lực để biến Văn phòng điều phối du lịch Mê-kông thành một tổ chúc liên chính phủ, được tài trợ hoàn toàn bởi các chính phủ GMS, và có đầy đủ tư cách pháp nhân và pháp lý để đảm nhiệm vai trò Ban thư ký của Nhóm công tác du lịch và Diễn đàn du lịch Mê-kông. Văn phòng điều phối du lịch Mê-kông đóng vai trò là phương tiện thúc đẩy hợp tác du lịch giữa chính phủ, khu vực tư nhân, các đối tác phát triển và các tổ chức xã hội dân sự.

Những điều chỉnh trong sắp xếp thể chế của các lĩnh vực giao thông, tạo thuận lợi thương mại và năng lượng cũng đang được xem xét. Đối với giao thông và tạo thuận lợi thương mại, trọng tâm hẹp của các cơ chế triển khai CBTA (tức là các Ủy ban Tạo thuận lợi giao thông vận tải quốc gia và Liên ủy ban) khiến chương trình nghị sự tạo thuận lợi thương mại rộng hơn ở ngoài phạm vi CBTA không thể giải quyết. Chương trình nghị sự này bao gồm hiện đại hóa hải quan, tự động hóa hải quan, các biện pháp SPS, phối hợp quản lý biên giới, và vai trò của khu vực tư nhân liên

3 ADB. 2016. Tài liệu Study on Strengthening the GMS Institutional Framework. Manila. 
quan đến các thủ tục phức tạp và nhiều cơ quan. Việc kích hoạt lại Nhóm công tác về tạo thuận lợi thương mại (TFWG), vốn đã không hoạt động kể từ năm 2007, sẽ đòi hỏi phải xem xét một vai trò nổi bật hơn cho các cơ quan hải quan và SPS để đảm bảo họ chấp nhận và hỗ trợ chương trình nghị sự rộng hơn về tạo thuận lợi thương mại. Hai nhóm nhỏ này (hải quan và SPS) được đề xuất thành lập trực thuộc Nhóm công tác về tạo thuận lợi thương mại mới được tái kích hoạt. Nhóm công tác được kích hoạt lại này sẽ cần xác định phạm vi chức năng của nó trong mối quan hệ với khung thể chế CBTA và các thỏa thuận phối hợp với các cơ quan GMS khác như Diễn đàn vận tải tiểu vùng và Diễn đàn hành lang kinh tế (ECF).

Đối với ngành năng lượng, xét tới tiến triển hạn chế của tiến trình hợp tác GMS trong các lĩnh vực dầu khí, than sạch, năng lượng tái tạo và hiệu quả năng lượng, vai trò và tính bền vững của Diễn đàn năng lượng tiểu vùng cần được xem xét lại. Trong khi đó, Ủy ban điều phối thương mại điện khu vực (RPCC) đã hoạt động tốt trong vai trò là thể chế đưa ra các quy tắc để điều chỉnh thương mại điện tiểu vùng. Ủy ban này đã thành lập hai nhóm công tác về các vấn đề pháp lý và tiêu chuẩn thực hiện và mã lưới điện, đóng vai trò là các cơ quan lâm thời cho tới khi RPCC có thể tiếp nhận hoàn toàn chức năng của hai nhóm này sau khi Ủy ban được thành lập đầy đủ như một cơ quan liên chính phủ có tư cách pháp nhân. Do đó, việc thành lập và vận hành đầy đủ RPCC là ưu tiên hàng đầu để GMS đạt được các bước tiến tiếp theo trong hội nhập thị trường điện.

Các cơ chế phối hợp không gian và đa ngành. Định hướng không gian và cách tiếp cận đa ngành của GMS SF-II là một chiến lược nhằm mang lại trọng tâm lớn hơn, sự gắn kết và trình tự hiệu quả hơn đối với các hoạt động can thiệp trong một không gian cụ thể để đạt được tác động lơn hơn. Tuy nhiên, cơ chế thể chế cho cách tiếp cận này vẫn chưa phát triển, với ECF và Diễn đàn Thống đốc GMS chủ yếu đóng vai trò là diễn đàn phối hợp và chia sẻ thông tin. Định hướng không gian như mường tượng trong GMS SF-II, theo đó mở rộng các hành lang thành mạng lưới các thành phố và đô thị (trái ngược với kết nối điểm tới điểm) sẽ phải tìm ra những cơ chế đáp ứng tốt hơn để giao dịch với các bên hữu quan đa dạng ở cấp quốc gia, bang hoặc tỉnh, và địa phương, với nhiệm vụ thiết kế, thực thi và quản lý các dự án. Nghiên cứu về tăng cường khung thể chế GMS đã khuyến nghị tái cấu trúc Diễn đàn Thống đốc GMS thành nhiều diễn đàn hành lang cụ thể và/hoặc các diễn đàn song phương, trong đó người đứng đầu các tỉnh và khu vực tư nhân địa phương của các tỉnh tiếp giáp nhau sẽ có những lợi ích và mối quan tâm chung. Vai trò của chính quyền địa phương sẽ đặc biệt quan trọng bởi họ là đối tượng thụ hưởng trực tiếp và là bên tham gia quy hoạch không gian. Các cơ chế thể chế cũng sẽ phải thúc đẩy quan hệ đối tác hiệu quả với khu vực tư nhân, cả thượng nguồn và hạ nguồn, ở giai đoạn lập kế hoạch và trong suốt quá trình thực hiện. Kinh nghiệm từ các khu vực khác trên thế giới có thể cung cấp một nguồn ý tưởng sáng tạo trong việc thiết kế các cơ chế thể chế dựa trên khu vực. Tuy nhiên, một khung thể chế dựa trên khu vực được xây dựng cho GMS nên được tùy chỉnh dựa trên điều kiện đặc trưng của các khu vực cụ thể, mà trong đó nếu có từ hai quốc gia trở lên, sẽ có thể có sự khác biệt rõ rệt về mức độ cam kết chính trị, mức độ tự

Quan hệ đối tác với các nhóm cộng đồng, doanh nghiệp vừa và nhỏ và các ngành công nghiệp. Có bằng chứng đáng khích lệ cho thấy rằng quan hệ đối tác với các bên liên quan, bao gồm các nhóm cộng đồng, đã được lồng ghép vào các dự án trong một số lĩnh vực, nổi bật là nông nghiệp, môi trường, thuận lợi hóa thương mại và du lịch. Các dự án nông nghiệp đã thí điểm thành công những cơ chế ở cấp cơ sở như hệ thống bảo lãnh có sự tham gia, thủ tục chứng nhận hữu cơ dựa trên cộng đồng cho những nông hộ quy mô nhỏ; và thư thỏa thuận giữa các nhà sản xuất nhỏ tham gia thí điểm những phương thức sản xuất nông nghiệp thân thiện với khí hậu và nhạy cảm với giới. Trong lĩnh vực môi trường, sáng kiến hành lang vận tải carbon thấp đã thu hút sự tham 
gia của các doanh nghiệp vừa và nhỏ (DNNVV) trong lĩnh vực vận tải, gồm cả đào tạo lái xe về cách thức lái xe thân thiện với hệ sinh thái. Du lịch, với vai trò một lĩnh vực ngành nghề, đã triển khai những cách tiếp cận nhiều bên, gồm các nhà cung cấp dịch vụ du lịch, khách sạn và lưu trú, các đơn vị quy hoạch du lịch và đô thị, các chuyên gia giao thông, chuyên gia di sản, chuyên gia xã hội và môi trường, cùng những bên liên quan khác. Diễn đàn Du lịch Mê-kông thường niên diễn đàn cao nhất của các bên liên quan trong ngành du lịch - mang đến một cơ hội tương tác bao trùm và định hướng kết quả để khuyến khích sự tham gia của cả khu vực nhà nước và tư nhân nhằm thúc đẩy du lịch trong GMS. Trên thực tế, khung thể chế cho du lịch là một ví dụ hữu ích về sự tham gia của các bên liên quan ở nhiều cấp khác nhau với những vai trò khác nhau.

Sự tham gia của các doanh nghiệp tư nhân. Khu vực doanh nghiệp tư nhân tiếp tục là đối tác chiến lược trong Chương trình $\mathrm{GMS}$, như được minh chứng bằng các cấu trúc và quy trình chính thức đã được thiết lập, như Hội đồng Kinh doanh GMS; các tổ chức đặc thù của ngành (ví dụ: Hiệp hội Vận tải hàng hóa GMS); có đại diện trong các cuộc họp và sự kiện của Tiểu vùng Mê-kông mở rộng như Diễn đàn Hành lang kinh tế (ECF); và tham gia những sáng kiến cụ thể của ngành. Ví dụ, dự án tăng cường quan hệ đối tác giữa cơ quan hải quan và khu vực tư nhân đã thu hút khu vực tư nhân tham gia thực hiện một khảo sát nhận thức kinh doanh về các hạn chế đối với tạo thuận lợi thương mại. Hoạt động xây dựng năng lực trong dự án này cũng bao gồm tập huấn cho các đại lý hải quan về các thông lệ thực hiện dựa trên quản lý rủi ro theo Công ước Kyoto sửa đổi. Khu vực tư nhân có vai trò tích cực hơn ở Trung Quốc, Thái Lan và Việt Nam vì một số lý do. Sau nhiều năm phát triển, khu vực tư nhân ở các quốc gia này có khả năng tài chính để đầu tư vào các dự án GMS. Mặt khác, do vấn đề tính bền vững của nợ công, đặc biệt ở Việt Nam, khu vực tư nhân đã trở nên tích cực hơn trong việc tài trợ cho các dự án cơ sở hạ tầng GMS. Hầu hết các dự án GMS khả thi về mặt kinh tế ở Việt Nam, như dự án đường cao tốc Móng Cái - Vân Đồn và Khu quá cảnh Lạng Sơn, đều được tài trợ bởi khu vực tư nhân trong nước

Các tập đoàn đa quốc gia cũng đầu tư vào nhiều dự án quan trọng trong GMS, đặc biệt là phát triển những đặc khu kinh tế (SEZ) dọc theo các hành lang GMS. Đặc khu kinh tế Savan-Seno tại Cộng hòa Dân chủ Nhân dân (CHDCND) Lào dọc theo Hành lang Kinh tế Đông - Tây là một ví dụ điển hình về sự quan tâm ngày càng tăng của các tập đoàn đa quốc gia tới tiềm năng của Chương trình GMS để liên kết các thị trường GMS.

Tuy nhiên, vẫn còn dư địa cho sự tham gia sâu hơn của khu vực tư nhân, cả trong nước và quốc tế, ở cấp độ các nhóm công tác nhằm giúp chính phủ hiểu rõ hơn nhu cầu đang thay đổi của khu vực doanh nghiệp trong những lĩnh vực cụ thể, và để lồng ghép những quan điểm và quan ngại của họ trong tất cả các sáng kiến của Chương trình GMS. Xét tới mục tiêu chung của các quốc gia GMS là tăng cường sự tham gia vào các chuỗi giá trị khu vực, việc thành lập những mạng lưới kinh doanh đặc thù của ngành có thể được cân nhắc ở cấp tiểu vùng, với sự liên kết với các cấu trúc chính thức của GMS như Hội nghị Quan chức Cấp cao. Ngoài ra, có thể khuyến khích đầu tư tư nhân vào các chuỗi cung ứng, trong các đặc khu kinh tế hoặc khu công nghiệp được thiết lập ở biên giới hoặc dọc theo hành lang. Khu vực tư nhân có thể là một đối tác trong việc theo đuổi mục tiêu tăng khả năng cạnh tranh bằng những cách thức "xanh" hơn, như thông qua phi các-bon hóa sản xuất công nghiệp, áp dụng các thông lệ canh tác nông nghiệp bền vững, và thúc đẩy hiệu quả năng lượng, bên cạnh những cách thức khác. Có thể tổ chức một diễn đàn chia sẻ thông tin cho mục đích này. Với thành công đã được minh chứng trên toàn cầu của khu vực tư nhân trong việc cung cấp hiệu quả các dịch vụ CNTT, và như được chứng tỏ bởi các sáng kiến 
thành công do khu vực tư nhân thúc đẩy trong Nền tảng Thương mại điện tử GMS, có thể thúc đẩy khai thác nguồn lực tư nhân để phát triển các ứng dụng CNTT trong nhiều sáng kiến lĩnh vực khác nhau, đặc biệt là các sáng kiến liên quan tới hoạt động xuyên biên giới, sử dụng Mạng lưới Siêu xa lộ Thông tin. Chương trình GMS cũng cần phát huy hiệu quả hơn nữa trong việc thu hút nguồn lực tư nhân trong các dự án đầu tư công thông qua hình thức đối tác công tư, đặc biệt trong cơ sở hạ tầng giao thông và năng lượng. Ngoài việc đóng vai trò nguồn tài trợ, khu vực tư nhân cũng có thể là một nguồn đổi mới sáng tạo trong việc phát triển cơ sở hạ tầng nhạy cảm về mặt sinh thái và có trách nhiệm xã hội.

Điều phối các đối tác phát triển. Các đối tác phát triển ngày càng đóng vai trò quan trọng trong Chương trình GMS, với bằng chứng là sự tham gia tích cực của họ tại Diễn đàn các Đối tác Phát triển được tổ chức thường niên như một phần của Hội nghị Bộ trưởng GMS, đặc biệt ở cấp độ các nhóm công tác trong lĩnh vực nông nghiệp, môi trường, du lịch và ở mức độ ít hơn là giao thông và tạo thuận lợi thương mại. Ho cũng thể hiện sự quan tâm tới việc hỗ trợ phát triển khu vực tư nhân và các hiệp hội ngành nghề. Đây là một lĩnh vực quan hệ đối tác có thể được khám phá thêm, bao gồm thúc đẩy mối liên kết giữa khu vực tư nhân trong GMS và các nước thứ ba. Các đối tác phát triển đã đóng góp nguồn lực đáng kể cho Chương trình GMS. Tính đến tháng 12/2017, trong tổng số 20,7 tỉ đô-la chi phí của 86 dự án đầu tư GMS do ADB hỗ trợ (vốn vay và tài trợ), 39\% là do $A D B$ cung cấp, $35 \%$ do các đối tác phát triển, và $26 \%$ do các chính phủ GMS. Con số này sẽ còn cao hơn nếu tính cả tài trợ song phương cho các chính phủ GMS. Sự đóng góp quan trọng của các đối tác phát triển cho Chương trình GMS có thể được ghi nhận thêm bằng cách đưa vào những dự án mà họ hỗ trợ trong RIF theo cách thức có hệ thống hơn.

Các chức năng của Ban thư ký. Vai trò của $A D B$ với tư cách nhà tài trợ chính, nhà môi giới trung thực, và ban thư ký điều phối đã được trích dẫn là một trong những thế mạnh của Chương trình GMS. Tuy nhiên, cần nâng cao trọng tâm lập kế hoạch và năng lực của Ban thư ký GMS do vai trò này đã trở nên quan trọng trong bối cảnh tính phức tạp ngày càng tăng của các vấn đề mà Chương trình GMS phải giải quyết. Lập kế hoạch chiến lược hiệu quả phụ thuộc vào chất lượng của việc phân tích, và điều này đến lượt nó sẽ hỗ trợ: (i) các quy trình ra quyết định, (ii) xây dựng các chiến lược ngành, và (iii) xác định các dự án tiềm năng trong khu vực. Các sản phẩm tri thức của GMS cần mang định hướng hành động để hỗ trợ xây dựng chiến lược hiệu quả.

Ở cấp quốc gia, hiệu quả hoạt động của các ban thư ký quốc gia có sự khác biệt đáng kể. Thiếu cán bộ và tình trạng luân chuyển cán bộ, các ưu tiên công việc cạnh tranh nhau, năng lực lập kế hoạch và điều phối yếu kém, cùng những hạn chế về tài chính nằm trong số những thách thức lớn mà các ban thư ký quốc gia đang phải đối mặt, mặc dù mức độ là khác nhau. Những hạn chế về năng lực này vẫn phổ biến, mặc dù ý tưởng trao quyền cho các ban thư ký quốc gia để đảm đương trách nhiệm lớn hơn đã được nêu ra nhằm thể hiện vai trò làm chủ lớn hơn của các quốc gia đối với Chương trình GMS vào năm thứ 25 của nó.

Những cải tiến trong Khung thể chế Tiểu vùng Mê-kông mở rộng. Trao quyền cho các Ban thư ký quốc gia có thể bao hàm việc trao cho họ trách nhiệm điều phối các giai đoạn khác nhau của chu trình dự án GMS ở trong nước và ở cấp tiểu vùng thông qua các nhóm công tác. Cách tổ chức này sẽ giúp việc phối hợp sát thực hơn và hỗ trợ mong muốn của các quốc gia GMS là tập trung vào thực hiện và giám sát kết quả. Các quốc gia GMS cũng có thể chủ trì việc điều phối các nhóm công tác theo ngành. Những điều này sẽ khẳng định sự trưởng thành của Chương trình GMS tại thời điểm các quốc gia GMS đang nâng cấp lên vị thế phát triển cao hơn, với các nhu cầu và nguyện vọng phức tạp hơn. $A D B$ sẽ vẫn là ban thư ký trung ương, nhưng vai trò của nó sẽ 
tập trung vào việc cung cấp các sản phẩm tri thức, tài chính và huy động các nguồn lực cho các dự án ưu tiên của GMS.

Nên khuyến khích sự linh hoạt trong thiết kế các sắp xếp thể chế. Điều này hàm ý rằng các nhóm công tác có thể được cấu trúc khác nhau - một số nhóm tiếp tục hoạt động theo các sắp xếp hiện thời, trong khi các nhóm khác chuyển đổi thành các mạng lưới, các nhóm chuyên gia đặc biệt hoặc các diễn đàn tri thức - tùy theo tình hình cụ thể. Các quốc gia GMS có thể xem xét thiết lập các cơ chế phối hợp dọc theo các ngành công nghiệp (các nhóm công tác hoặc diễn đàn theo ngành), với sự tham gia tích cực của khu vực tư nhân, trong bối cảnh việc hội nhập vào các chuỗi giá trị khu vực và toàn cầu đã nổi lên như một chủ đề chung trong chương trình nghị sự quốc gia. Cần đẩy mạnh việc sử dụng công nghệ số hóa (ví dụ: sử dụng các ứng dụng di động để tạo thuận lợi cho việc chia sẻ thông tin, sử dụng các chương trình tương tác để cập nhật cơ sở dữ liệu, tiến hành các cuộc họp ảo, v.v.) để tăng cường hiệu quả và giảm chi phí vận hành.

\section{Kết luận của Đánh giá giữa kỳ, khuyến nghị và bước đi tiếp theo}

Đánh giá giữa kỳ đã cung cấp nhiều thông tin về các khía cạnh khác nhau của Chương trình GMS trong 5 năm đầu triển khai GMS SF-II. Tiến bộ đạt được trong rất nhiều sáng kiến lĩnh vực khác nhau là đáng ghi nhận, cho thấy sự phù hợp và đáp ứng không ngừng của Chương trình GMS trong việc hỗ trợ các ưu tiên phát triển quốc gia. Đồng thời, Đánh giá giữa kỳ cũng đã phát hiện được những khiếm khuyết về quy trình và yếu kém về thể chế mà có thể ảnh hưởng đến hiệu suất và hiệu quả của việc thực hiện chương trình. Những nhược điểm này phải được khắc phục như một vấn đề ưu tiên trong 5 năm còn lại của GMS SF-II, khi các sáng kiến mới theo lĩnh vực được đưa ra trong một môi trường ngày càng phức tạp với tiến độ hội nhập và cạnh tranh nhanh chóng. Một kịch bản "giữ nguyên như cũ" có thể không còn áp dụng được đối với khu vực GMS, nếu nó muốn tiếp tục đóng một vai trò có ý nghĩa tại Châu Á năng động.

Dưới đây là những kết luận và khuyến nghị từ Đánh giá giữa kỳ, cũng như bước đi tiếp theo.

GMS SF-II tiếp tục phù hợp và đáp ứng những ưu tiên phát triển của các quốc gia GMS, đặc biệt nhất là trong lĩnh vực kết nối cơ sở hạ tầng và phát triển hành lang kinh tế - vốn có liên hệ trực tiếp với mục tiêu chung là hướng tới đa dạng hóa kinh tế và tham gia các chuỗi giá trị khu vực và toàn cầu. Khái niệm mở rộng về các hành lang kinh tế như là những mạng lưới thay vì kết nối điểm tới điểm đã buộc hoạt động phát triển không gian phải được điều phối theo cách tiếp cận toàn GMS. Cần xây dựng các quy hoạch phát triển không gian và phát triển đa ngành toàn diện cho các cụm đô thị ưu tiên và các cửa khẩu có giá trị chiến lược ở cả cấp quốc gia và tiểu vùng. Những quy hoạch phát triển toàn diện này sẽ tránh các hoạt động can thiệp đa ngành ngẫu nhiên và cho phép phân tích toàn diện các khía cạnh chính sách, thể chế, kinh tế, dân cư và xã hội cùng ảnh hưởng của chúng, và đưa vào trong các quyết định về chính sách và đầu tư.

GMS nên chủ động tìm kiếm các mối liên kết bên ngoài tiểu vùng để phát huy hiệu quả kết nối nội bộ và tăng cường hội nhập tiểu vùng, với cơ hội mở rộng thương mại sang các thị trường khác. Kết nối giao thông đường bộ với Nam Á giờ đây đã dễ dàng hơn khi Mi-an-ma mở cửa, cùng với việc mở rộng và cấu hình lại những tuyến đường phía tây của các hành lang kinh tế GMS. Các sáng kiến khác, như Sáng kiến Vành đai và Con đường của Cộng hòa Nhân dân Trung 
Hoa, cũng đang mở thêm cơ hội cho GMS kết nối với các thị trường khác. Với vai trò là thể chế tạo thuận lợi chủ đạo trong tiểu vùng, Chương trình GMS cần phối hợp hiệu quả hơn không chỉ với ASEAN, mà còn với những sáng kiến khác do các quốc gia thành viên khởi xướng, như Sáng kiến Vành đai và Con đường; một số thể chế chức năng hoạt động tại các quốc gia thành viên, như Chiến lược Hợp tác kinh tế Ayeyawady - Chao Phraya - Mekong; và các sáng kiến khác liên quan tới Cam-pu-chia, CHDCND Lào, Mi-an-ma và Việt Nam.

Quỹ đạo mở rộng ra ngoài khu vực khiến Chương trình GMS buộc phải cân bằng trọng tâm vào vận tải đường bộ của mình với sự chú trọng ngày càng tăng tới các phương thức vận tải khác. Sự phát triển của kết nối đường sắt và liên kết đa phương thức đường bộ - đường sắt đã được uu tiên, nhưng vẫn còn dư địa để phát triển hơn nữa các liên kết vận tải đường bộ - đường thủy, xét tới thực tế rằng $90 \%$ kim ngạch thương mại của GMS với các thị trường bên ngoài là dựa trên đường thủy. Thị trường các dịch vụ vận tải cũng cần được phát triển để tạo điều kiện cho ngành dịch vụ hậu cần - một thành phần quan trọng của thương mại toàn cầu - tăng trưởng để đáp ứng nhu cầu đang gia tăng.

Kết nối giao thông đang đạt được tiến triển tốt, nhưng các biện pháp tạo thuận lợi cho thương mại và vận tải chưa theo kịp tiến độ này, do đó làm hạn chế hoặc trì hoãn lợi ích từ các dự án đầu tư cơ sở hạ tầng. Với những hạn chế tiếp tục cản trở CBTA, cho dù có tiến triển dần dần trong việc thực thi, cần thiết lập các cơ chế thể chế dành riêng cho hải quan và SPS trong phạm vi Nhóm công tác Tạo thuận lợi thương mại (TFWG). Điều này sẽ giúp tập trung và tăng tốc hợp tác tiểu vùng trong lĩnh vực hải quan và SPS bên ngoài khuôn khổ CBTA, thông qua việc tuân thủ chung các tiêu chuẩn và thông lệ tốt quốc tế được quy định bởi các công ước và hiệp định quốc tế. Các hiệp định tạo thuận lợi cho vận tải song phương và ba bên cũng có thể hữu ích nhằm thúc đẩy tự do hóa hơn nữa thị trường vận tải GMS.

Phát triển dịch vụ hậu cần là chì khóa để tăng cường khả năng cạnh tranh của các hành lang kinh tế GMS và thúc đẩy các quốc gia GMS hội nhập vào các chuỗi giá trị khu vực và toàn cầu. Sự tham gia của khu vực tư nhân trong nước và quốc tế vào phát triển hậu cần là rất quan trọng để đảm bảo tính bền vững của các dự án hậu cần, do các dịch vụ hậu cần chủ yếu được định hướng bởi nhu cầu. Phát triển dịch vụ hậu cần sẽ đòi hỏi đầu tư vào các hoạt động gia tăng giá trị cho vận tải như các trung tâm hậu cần, cảng cạn và kho lưu trữ, bên cạnh các hạng mục khác, kèm theo đó là sự hỗ trợ về mặt chính sách, thể chế và pháp lý.

Cần chú trọng đặc biệt tới sự phát triển của các đặc khu kinh tế (SEZ), nhất là ở những vùng biên giới dọc theo các hành lang kinh tế. Các SEZ sẽ đóng vai trò ngày càng quan trọng như các địa điểm đầu tư, tạo ra môi trường cạnh tranh để hỗ trợ các chuỗi cung úng toàn cầu. Lợi thế cạnh tranh về địa điểm của các SEZ - kết hợp với cơ sở hạ tầng và cơ sở vật chất khác, ưu đãi tài chính và tiếp cận các thị trường nguồn lực đầu vào - cho phép các đặc khu kinh tế đáp ứng những yêu cầu cụ thể về chuỗi cung ứng của các nhà đầu tư, do chúng có thể tạo thuận lợi cho dòng lưu chuyển hàng hóa và sản phẩm. Các SEZ cũng có thể tăng cường lợi thế so sánh cho doanh nghiệp thông qua việc phân cụm công nghiệp liên kết các nhà cung cấp và nhà bán hàng chuyên biệt của địa phương, gồm cả các doanh nghiệp vừa và nhỏ, với các công ty trong đặc khu. Chiến lược không gian của Chương trình GMS nên xem xét vai trò chiến lược của các $S E Z$ trong việc tăng cường cơ hội hội nhập vào chuỗi giá trị.

Thương mại điện tử sẽ là một động lực quan trọng của tăng trưởng kinh tế và chuyển đổi ngành nghề, đặc biệt đối với các doanh nghiệp vừa và nhỏ (DNVVN), là đối tượng có thể được hưởng 
lợi nhiều hơn từ việc giảm chi phí tìm kiếm thông tin và chi phí giao dịch, từ đó cải thiện hiệu quả hoạt động chung, xét tới quy mô và phạm vi hoạt động của các DNVVN. Các hoạt động tính tới nay của Nền tảng Thương mại điện tử GMS đã mang lại những kết quả cụ thể, và sẽ được đẩy mạnh trong những năm tới. Mặc dù khu vực tư nhân được kỳ vọng đóng vai trò quan trọng trong việc phát triển và sử dụng thương mại điện tử, nhưng cần nhiều hơn nỗ lực có phối hợp từ các chính phủ GMS để cho phép nhiều doanh nghiệp hơn được hưởng lợi từ sự đổi mới này bằng cách tạo ra môi trường chính sách phù hợp (nghĩa là giao dịch không giấy tờ, bảo vệ thông tin cá nhân trực tuyến, bảo vệ người tiêu dùng trực tuyến, bảo vệ quyền sở hữu trí tuệ, v.v.); và thúc đẩy sự sẵn sàng của thương mại điện tử trong các công ty (ví dụ: thúc đẩy việc truy cập vào các mạng lưới thông tin một cách dễ dàng và ít tốn kém).

Khi các quốc gia GMS phát triển thành những nhà cung cấp hàng hóa và dịch vụ cạnh tranh trên toàn cầu, chất lượng và chi phí ngày càng trở nên quan trọng. Điều này đòi hỏi phải liên kết những sáng kiến nhất định giữa các ngành một cách có hệ thống nhằm đạt được nhưng khía cạnh nêu trên. Chẳng hạn, mục tiêu đưa các quốc gia GMS trở thành nhà cung cấp hàng đầu các sản phẩm nông nghiệp an toàn và thân thiện với môi trường sẽ đòi hỏi phải giải quyết những khoảng trống trong chuỗi giá trị sản phẩm nông nghiệp an toàn và thân thiện với môi trường thông qua hỗ trợ cơ sở hạ tầng, tạo thuận lợi thương mại, dịch vụ hậu cần, các biện pháp SPS, và thực hành nông nghiệp bền vưng. Chương trình GMS cần thiết lập các cơ chế thích hợp để liên kết những hoạt động can thiệp hỗ trợ giữa các lĩnh vực để phục vụ cho các sáng kiến chiến lược.

Cần bắt đầu cải thiện các quy trình lập kế hoạch và xây dựng chương trình của GMS thông qua những hướng dẫn để bảo đảm có sự gắn kết và nhất quán giữa các mục tiêu, chiến lược, chương trình và dự án cũng như giám sát tiến độ và kết quả. Các hướng dẫn này phải có khả năng xác định rõ thứ bậc về tầm nhìn, sứ mệnh, mục tiêu, chiến lược và dự án; cung cấp hướng dẫn thích hợp trong tất cả các giai đoạn; giúp thấm nhuần quy tắc chung của quy trình; và thúc đẩy sự đồng bộ hóa tốt hơn khung thời gian giũa các chiến lược ngành và Chương trình GMS. Các hướng dẫn này cũng cần xác định trách nhiệm thể chế ở cấp quốc gia và tiểu vùng, gồm cả yêu cầu về báo cáo.

Giám sát kết quả đòi hỏi phải được ưu tiên chú trọng, do phần quan trọng này của chu trình lập kế hoạch đã không được thực hiện trong nửa đầu của GMS SF-II. Các mục tiêu (hoặc kết quả) ở cấp độ chương trình và ngành cần được xác định ngay từ đầu và bảo đảm yêu cầu về tính cụ thể, có thể đo lường, có thể đạt được, phù hợp và có thời hạn (SMART). Hầu hết các chiến lược ngành bắt đầu bằng một tuyên bố tầm nhìn, tiếp theo là đưa ra các chiến lược mà không nêu cụ thể các mục tiêu mà chiến lược nhằm đạt tới. Hội nghị Quan chức cao cấp, nơi trực tiếp nghe báo cáo của các nhóm công tác, cần đảm bảo rằng tất cả các ngành đều xác định rõ những mục tiêu của mình như là điểm bắt đầu của việc theo dõi kết quả. Các chỉ số đầu ra và kết quả cũng cần được cụ thể hóa. Các nhóm công tác của từng lĩnh vực cần chịu trách nhiệm xây dựng các khung giám sát kết quả tương ứng, trong khi $\mathrm{ADB}$ cung cấp hỗ trợ kỹ thuật và tư vấn.

Cần cải thiện khái niệm, quy trình và các nguyên tắc của RIF để nâng cao hiệu quả của nó như là một tài liệu định hướng xây dựng chương trình. Các mũi nhọn chiến lược và ưu tiên hoạt động trong Kế hoạch Hành động Hà Nội (HAP) sẽ phải được tích hợp trong các tiêu chí lựa chọn của RIF để đảm bảo chúng được phản ánh trong danh mục dự án GMS. Điều này hàm ý rằng RIF cần có mức bao phủ phổ cập hơn để đưa vào cả những dự án hiện đang triển khai, vốn được khởi xướng như một phần của các khung chiến lược trước đó, cũng như các dự án được lên kế hoạch trong các khung chiến lược tiếp theo. Là một tài liệu sống, RIF cần có khả năng phản ánh sự thay 
đổi trong các ưu tiên và trình tự phù hợp của các dự án. RIF cũng cần đưa vào những dự án được tài trợ bởi các chính phủ GMS cũng như các đối tác phát triển.

Sự tham gia của khu vực tư nhân trong các cấu trúc, cuộc họp và sự kiện của GMS nên được dần chuyển thành sự tham gia vào những sáng kiến cụ thể. Cần khuyến khích sự tham gia của khu vực tư nhân ở cấp độ các nhóm công tác, không chỉ để hiểu rõ hơn những quan điểm và mối quan tâm của họ trong tất cả các lĩnh vực của Chương trình GMS, mà còn khai thác những cách tiếp cận và giải pháp sáng tạo cho các vấn đề phát triển. Trong khi tiếp tục thúc đẩy tài trợ của khu vực tư nhân cho các dự án đầu tư công (thông qua đối tác công - tư'), cần khám phá cả những lĩnh vực khác. Khu vực tư nhân có thể là một đối tác trong việc theo đuổi cách thức "xanh" hơn để đạt được khả năng cạnh tranh và thông qua những sáng tạo, đổi mới trong cơ sở hạ tầng thân thiện với môi trường và có trách nhiệm xã hội.

Cần bắt đầu cải tiến các cơ chế thể chế của GMS. Vào năm thứ 25 kể từ khi thành lập, Chương trình GMS đã đạt đến độ chín để thể hiện vai trò sở hữu và cam kết của mình một cách cụ thể hơn. Những sắp xếp thể chế trong khuôn khổ được tăng cường cần dựa trên các nguyên tắc trao quyền cho các ban thư ký quốc gia, cho phép sự linh hoạt trong những cách thức tổ chức bên ngoài các cấu trúc chính thức (ví dụ: các nhóm chuyên gia đặc biệt, mạng lưới và diễn đàn điện tử) và tăng cường sử dụng các quy trình được hỗ trợ bởi CNTT để hoạt động hiệu quả hơn. Những sắp xếp mới có thể đòi hỏi các quốc gia GMS giữ vai trò chủ trì trong các nhóm công tác theo lĩnh vực; còn Hội nghị Quan chức cao cấp sẽ thực hiện các chức năng giám sát mạnh mẽ hơn đối với các nhóm công tác, đặc biệt liên quan đến việc thiết lập mục tiêu và giám sát kết quả.

Những phát hiện và khuyến nghị nêu trên của Đánh giá giữa kỳ được phản ánh trong Kế hoạch Hành động Hà Nội (HAP) này. Một số trong đó đã được bao hàm trong các động lực và ưu tiên mới của các chiến lược ngành tiếp theo. HAP cũng phản ánh chương trình nghị sự còn dang dở của GMS SF-II, đáng chú ý là trong các lĩnh vực giao thông, phát triển đô thị, năng lượng, nông nghiệp, môi trường, du lịch, tạo thuận lợi thương mại, phát triển nguồn nhân lực và CNTT. Những đề xuất cải tiến quy trình và thể chế được đưa ra trong Phần $\mathrm{V}$ về thực thi. 


\section{NHỮNG DIỄN BIẾN VÀ THÁCH THỨC CỦA KHU VỰC VÀ TOÀN CẦU}

Khung Chiến lược Chương trình Hợp tác Kinh tế Tiểu vùng Mê-kông mở rộng giai đoạn 20122022 (GMS SF-II) được hình thành trong những năm sau cuộc khủng hoảng tài chính toàn cầu năm 2008 - cuộc khủng hoảng đã cho thấy Châu Á có khả năng thích ứng tốt hơn so với phần còn lại của thế giới, cho dù thương mại toàn cầu nói chung bị thu hẹp. Các quốc gia GMS thể hiện khả năng thích ứng tương tự thông qua sự kết hợp giữa nền tảng kinh tế vĩ mô lành mạnh và quan hệ thương mại với một số nền kinh tế sôi động nhất Châu Á bằng các mạng lưới sản xuất khu vực. Cuộc khủng hoảng tài chính toàn cầu đã cho thấy một bài học quan trọng: mặc dù tăng trưởng dựa trên xuất khẩu phục vụ tốt cho các nền kinh tế đang phát triển trong giai đoạn hậu chiến, song triển vọng tăng trưởng trì trệ kéo dài ở các nền kinh tế phát triển gợi ý về sự tái cân bằng hướng tới các thị trường trong nước và khu vực. Điều này đòi hỏi những cải cách cơ cấu sâu hơn và toàn diện hơn để thúc đẩy nhu cầu nội địa thông qua đầu tư công, khả năng cạnh tranh, năng suất và phát triển tài chính để tái phân bổ tiết kiệm vào kênh đầu tư sản xuất. Cuộc khủng hoảng này cũng xác định sự cần thiết phải đẩy nhanh hội nhập khu vực và tự do hóa thương mại để mở rộng quy mô thị trường, tạo thuận lợi cho sự lưu chuyển hàng hóa và dịch vụ và thu hút đầu tư.

Triển vọng kinh tế trung hạn của GMS là đầy hứa hẹn, dựa trên mức tăng trưởng ổn định kể từ giai đoạn hậu khủng hoảng, và càng sáng sủa hơn nhờ tác động của việc đa dạng hóa kinh tế vào các hoạt động gia tăng giá trị cao hơn trong sản xuất, tăng trưởng trong lĩnh vực dịch vụ và cải cách doanh nghiệp nhà nước, bên cạnh các hoạt động khác. Tuy nhiên, dù triển vọng là rất khả quan, vẫn có những thách thức cần giải quyết để duy trì và thúc đẩy tăng trưởng. Đa dạng hóa kinh tế sẽ đòi hỏi cải thiện cả nguồn cung và chất lượng lao động. Cải cách các thể chế giáo dục và đào tạo sẽ rất quan trọng. Phải nâng cao khả năng cạnh tranh của doanh nghiệp, đặc biệt các doanh nghiệp vừa và nhỏ. Nhưng thách thức bao gồm quản lý lạm phát và tỷ giá hối đoái, tạo ra một môi trường thuận lợi cho kinh doanh, và theo đuổi con đường phát triển thân thiện với môi trường. Phát triển đô thị là cần thiết để tạo ra mật độ phù hợp nhằm đạt được lợi thế kinh tế nhờ quy mô và thu hút đầu tư, từ đó sẽ tạo đà cho tri thức, kỹ năng và đổi mới. Đồng thời, cần hỗ trợ khả năng thích ứng về xã hội thông qua các hệ thống bảo trợ xã hội để duy trì và nâng cao hơn nữa những thành tựu trong xóa đói giảm nghèo và hòa nhập xã hội.

Con đường đi tới sự hồi phục bền vững của các nền kinh tế GMS trong trung hạn sẽ diễn ra trong bối cảnh có những diễn biến quan trọng tại châu Á. Chương trình nghị sự 2025 của Hiệp hội các Quốc gia Đông Nam Á đã kêu gọi làm sâu sắc hơn nữa các sáng kiến hội nhập. Các thỏa thuận thương mại khu vực toàn diện liên quan đến Hiệp hội các Quốc gia Đông Nam Á và những đối tác thương mại lớn của tổ chức này đang được đàm phán để không những thúc đẩy gia tăng thương mại, mà còn nhằm đạt được sự hiểu biết về các khía cạnh chính sách và quản trị của chuỗi giá trị toàn cầu và vai trò của các doanh nghiệp vừa và nhỏ trong đó. Một diễn biến đáng lưu ý khác là việc huy động nguồn vốn lớn cho cơ sở hạ tầng của các nền kinh tế lớn nhất và phát 
triển nhanh nhất thế giới, đi kèm với đó là việc thành lập các ngân hàng đa phương mới, quỹ đầu tư tư nhân, và các quỹ song phương đặc biệt cho cơ sở hạ tầng. Sáng kiến Vành đai và Con đường của của Cộng hòa Nhân dân (CHND) Trung Hoa và Hợp tác Lan Thương - Mê-kông, với mục đích gần giống với Chương trình GMS, mang đến nhưng cơ hội quan trọng cho tiểu vùng và bên ngoài để thúc đẩy mạnh mẽ hơn nữa chương trình nghị sự kết nối. Trong khi đó, vào tháng 2 năm 2017, Mi-an-ma đã trở thành thành viên thứ bảy của Chương trình Hợp tác kinh tế Nam Á, mở đường cho việc thiết lập những mối liên kết lớn hơn và mạnh mẽ hơn giữa khu vực Nam Á và Đông Nam Á.

Hai sáng kiến toàn cầu mang tính đột phá đã được khởi xướng trong năm 2016, gồm các Mục tiêu phát triển bền vững và Thỏa thuận Paris 2016 trong phạm vi Công ước Khung của Liên hợp quốc về Biến đổi khí hậu, bắt đầu có hiệu lực vào tháng 11 năm 2016. Chúng phản ánh những khát vọng chung toàn cầu mà có thể đạt được thông qua các hoạt động can thiệp có hệ thống ở cấp quốc gia và thông qua hợp tác khu vực. Các quốc gia GMS đã bắt đầu "nội địa hóa" các Mục tiêu phát triển bền vững thông qua những cam kết được khẳng định trên toàn quốc. Trọng tâm của Chương trình GMS trong các lĩnh vực giao thông và kết nối thị trường, thích ứng biến đổi khí hậu, kiểm soát bệnh truyền nhiễm, an ninh lương thực và an toàn thực phẩm, bên cạnh các lĩnh vực khác, là gắn kết chặt chẽ và có thể đóng góp thiết thực vào chương trình nghị sự phát triển toàn cầu. Tính biến động liên tục và đầy thách thức của cả khu vực và toàn cầu cho thấy cần có cách tiếp cận hợp lý với mục tiêu rõ ràng để thực hiện các chiến lược của Chương trình GMS trong trung hạn. 


\section{KẾ HOACH HÀNH ĐộNG HÀ NộI GIAI ĐOAN 2018-2022}

\section{A. Khung định hướng}

Kế hoạch Hành động Hà Nội giai đoạn 2018-2022 (HAP) dựa trên những tiến triển đạt được trong nửa đầu của GMS SF-II, giai đoạn từ 2012 tới 2017 (Hình 2). Kế hoạch này nêu ra cả chương trình nghị sự chưa hoàn thành và chương trình nghị sự mở rộng cho giai đoạn trung hạn, dựa trên kết quả đánh giá giữa kỳ, và được dự kiến đóng vai trò khung lập kế hoạch để định hướng việc xác định, lựa chọn và ưu tiên các dự án cho Khung Đầu tư vùng (RIF). Những hành động chính phản ánh các mũi nhọn chiến lược và ưu tiên hoạt động cho từng lĩnh vực đã được xác định trong Phụ lục cho mục đích này. HAP có bốn yếu tố chính:

(i) một chiến lược không gian tập trung vào các hành lang kinh tế;

(ii) tinh chỉnh các chiến lược và ưu tiên hoạt động của ngành;

(iii) cải thiện các hệ thống và quy trình lập kế hoạch, xây dựng chương trình và giám sát; và

(iv) cải tiến trong sắp xếp thể chế và quan hệ đối tác.

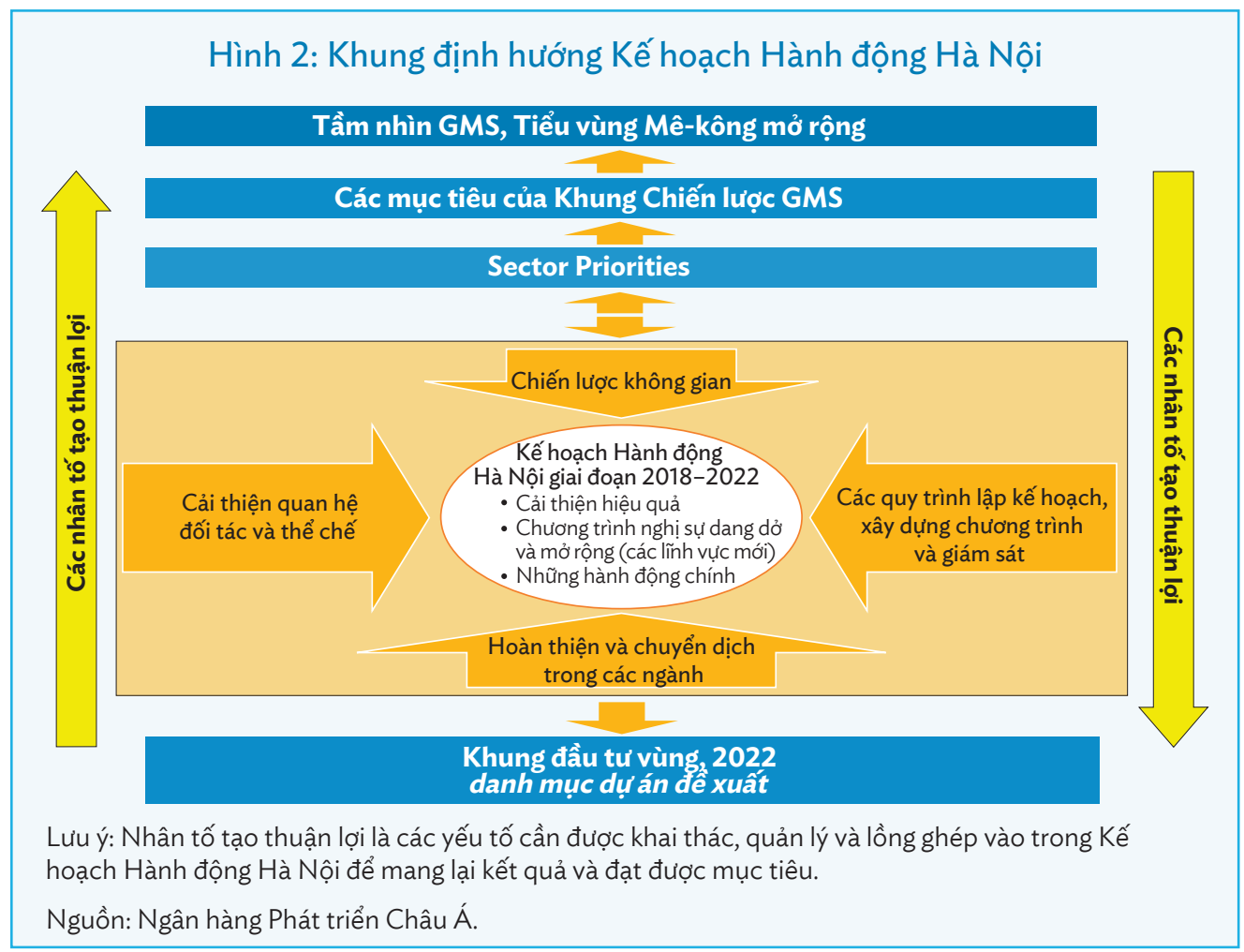




\section{B. Chiến lược không gian tập trung vào các hành lang kinh tế}

Việc chuyển đổi các hành lang giao thông thành hành lang kinh tế là chiến lược được tuyên bố từ lâu của Chương trình GMS, kể từ GMS SF-I. Những bài học kinh nghiệm được đúc rút qua nhiều năm cho thấy các hành lang kinh tế không phải là kết nối tuyến tính hoặc kết nối điểm tới điểm; rằng quá trình chuyển đổi không nhất thiết phải tuần tự; và rằng mặc dù các hành lang giao thông là điểm khởi đầu, song cơ sở hạ tầng chỉ có thể cân bằng ở một múc độ nhất định so với các lực đẩy thị trường. Việc phát triển các hành lang kinh tế đã được thừa nhận là một quy trình phức tạp hơn nhiều, đòi hỏi phải xem xét các chiều cạnh không gian của những thay đổi trong cấu trúc kinh tế và xã hội, là kết quả của tăng trưởng kinh tế và tính liên kết ngày càng gia tăng của tiểu vùng.

Việc tái định hình ba hành lang kinh tế ưu tiên của GSM trong năm 2016 là một phản ứng trước những thay đổi mạnh mẽ diễn ra trong tiểu vùng, tập trung vào các khu vực có tiềm năng tốt nhất để trở thành hành lang kinh tế vận hành đầy đủ chức năng, từ đó tối đa hóa khả năng đóng góp vào tăng thu nhập và việc làm. Quá trình này bám sát cách tiếp cận được nêu trong GMS SF-II về mở rộng và làm sâu sắc thêm khái niệm các hành lang kinh tế bằng việc liên kết chúng với các thành phố và đô thị hành lang như một phương thức để thiết lập mối liên kết giữa thành thị - nông thôn, từ đó mở rộng phân phối lợi ích giữa các khu vực tiến bộ và tụt hậu. Trong phạm vi của GMS SF-II, phát triển đô thị đã trở thành lĩnh vực ưu tiên trọng tâm, bên cạnh việc phát triển các đô thị hành lang, đô thị loại hai và khu vực biên giới.

Trong trung hạn, mạng lưới các hành lang, thay vì những hành lang riêng rẽ, sẽ đóng vai trò cấu trúc không gian để xác định những lĩnh vực ưu tiên đầu tư lớn trong GMS.

Việc này sẽ bao gồm hai hành động:

(i) Xây dựng các quy hoạch khu vực đa ngành cho những khu vực ưu tiên dọc theo các hành lang (các cụm đô thị và khu vực cửa khẩu). Những quy hoạch này sẽ mang lại nền tảng vững chắc hơn cho các quyết định đầu tư cũng như các can thiệp mềm. Chúng không chỉ tập trung vào cơ sở hạ tầng đô thị và công trình (giao thông, điện, nước và vệ sinh), mà còn tập trung vào các can thiệp chính sách nảy sinh từ quá trình đô thị hóa (ví dụ, khung pháp lý về đất đai, nhà ở và các khu định cư đô thị, dịch vụ vận tải, các biện pháp giảm thiểu và thích nghi biến đổi khí hậu, v.v.) cũng như các sáng kiến chính sách cần thiết để khuyến khích sự tham gia của khu vực tư nhân. Việc lập quy hoạch đa ngành hiệu quả đòi hỏi một quy trình có sự tham gia của các bên liên quan trong những lĩnh vực chủ chốt như nhượng quyền vận tải, phát triển dịch vụ hậu cần, phát triển nhà ở, cung cấp dịch vụ y tế - giáo dục và các dịch vụ tài chính.

(ii) Cân bằng tính kết nối bên ngoài với kết nối bên trong để phân phối tăng trưởng công bằng. Điều này đòi hỏi chú trọng lớn hơn tới việc phát triển các mối liên kết thành thị - nông thôn, từ đó hỗ trợ các chiến lược mới nổi về xây dựng chuỗi giá trị lương thực và phát triển các điểm đến thứ cấp trong du lịch. Các chiến lược phát triển khu vực sẽ bổ sung cho phát triển nông thôn, vốn vẫn là một thách thức đối với các quốc gia GMS. 
Từ quan điểm thể chế, cách tiếp cận quy hoạch không gian toàn GMS sẽ đòi hỏi sự liên hệ chặt chẽ giữa quy hoạch không gian quốc gia và tiểu vùng. Điều này hàm ý sự cần thiết phải có các diễn đàn hợp tác xuyên biên giới dưới hình thức các mạng lưới đô thị, cụm công nghiệp, và quan hệ đối tác kinh doanh chiến lược.

\section{Tinh chỉnh các chiến lược và ưu tiên của ngành}

Các ưu tiên hoạt động theo ngành trong HAP được xây dựng dựa trên cơ sở các chiến lược ngành kế tiếp, kết quả thảo luận của các nhóm công tác, tham vấn ngành và quốc gia, và đánh giá giữa kỳ. Các ưu tiên hoạt động này được dự kiến sẽ định hướng cho việc xây dựng các chương trình và dự án cho RIF, và do vậy sẽ là một phần của các hướng dẫn lựa chọn dự án cho RIF. Đối với một số ngành như phát triển đô thị, tạo thuận lợi thương mại và y tế, các ưu tiên hoạt động vẫn đang được xây dựng và sẽ được đưa vào các bản cập nhật tiếp theo của HAP hoặc RIF. Chi tiết về các ưu tiên hoạt động theo ngành và các hành động chính tương ứng được nêu trong Phụ lục.

Các chiến lược ngành kế tiếp đã bắt đầu phản ánh rõ ràng hơn nhiều nguyên tắc định hướng được nêu trong GMS SF-II. Chúng bao gồm tính trọng tâm và chọn lọc lớn hơn, cân bằng giữa các cấu phần phần cứng và phần mềm, gia tăng chú ý tới mối liên kết giữa các ngành, và nhận thức được chương trình hội nhập khu vực rộng hơn. Hai thách thức lớn trong việc thực hiện HAP gồm: trước tiên, bảo đảm rằng các nguyên tắc này cũng được tuân thủ trong quá trình xây dựng RIF để bảo đảm các chương trình và dự án hoàn toàn phù hợp với các ưu tiên hoạt động của ngành; và thứ hai, phải xây dựng và thực thi đầy đủ khung giám sát kết quả, với các trách nhiệm thể chế cụ thể được xác định ở các cấp độ khác nhau của khung thể chế GMS.

\section{Giao thông}

Tầm nhìn dài hạn của Chiến lược Giao thông 2030 (TrSS 2030) là "một hệ thống giao thông Tiểu vùng Mê-kông mở rộng liền mạch, hiệu quả, đáng tin cậy và bền vững". Tầm nhìn này giữ lại nội dung thực chất của tầm nhìn Chiến lược Giao thông 2015 (TrSS 2015) và bổ sung thêm "hiệu quả", "đáng tin cậy" và "bền vững" như những đặc điểm đáng mong đợi của ngành (Hình 3). Những mũi nhọn chiến lược của Chiến lược Giao thông 2030 phản ánh chương trình nghị sự còn dang dở của Chiến lược Giao thông 2015 (các liên kết hành lang kinh tế, CBTA, an toàn đường bộ); hoàn thiện cách tiếp cận phát triển vận tải đa phương thức; và một chương trình nghị sự mở rộng bao gồm phát triển hậu cần và quản lý tài sản đường bộ. Các mũi nhọn chiến lược này bao gồm:

(i) Hoàn thành mạng lưới hành lang giao thông và cải thiện liên kết với khu vực Nam Á và Đông Nam Á. Với việc các tuyến đường kết nối theo định dạng ban đầu của Hành lang Kinh tế Đông - Tây (EWEC), Hành lang Kinh tế Bắc - Nam (NSEC) và Hành lang Kinh tế phía $\mathrm{Nam}(\mathrm{SEC})$ hầu hết đã hoàn thành, ngoại trừ một số đoạn của EWEC ở Mi-an-ma và SEC ở Cam-pu-chia, các hoạt động sẽ tập trung vào nâng cấp hoặc khôi phục các đoạn chưa hoàn thiện trong tuyến ban đầu của EWEC và SEC; và các đoạn mới, đặc biệt ở Cộng hòa Dân chủ Nhân dân Lào và Mi-an-ma để giải quyết những liên kết còn thiếu và nút thắt trong các hành lang kinh tế mới được định hình lại. Để thiết lập liên kết với Nam Á, một tiểu hành lang mới đã được thêm vào NSEC, nối liền Mandalay với Tamu tại biên giới với Ấn Độ. 
Hình 3: Tầm nhìn và các ưu tiên hoạt động của Chiến lược Giao thông I và II
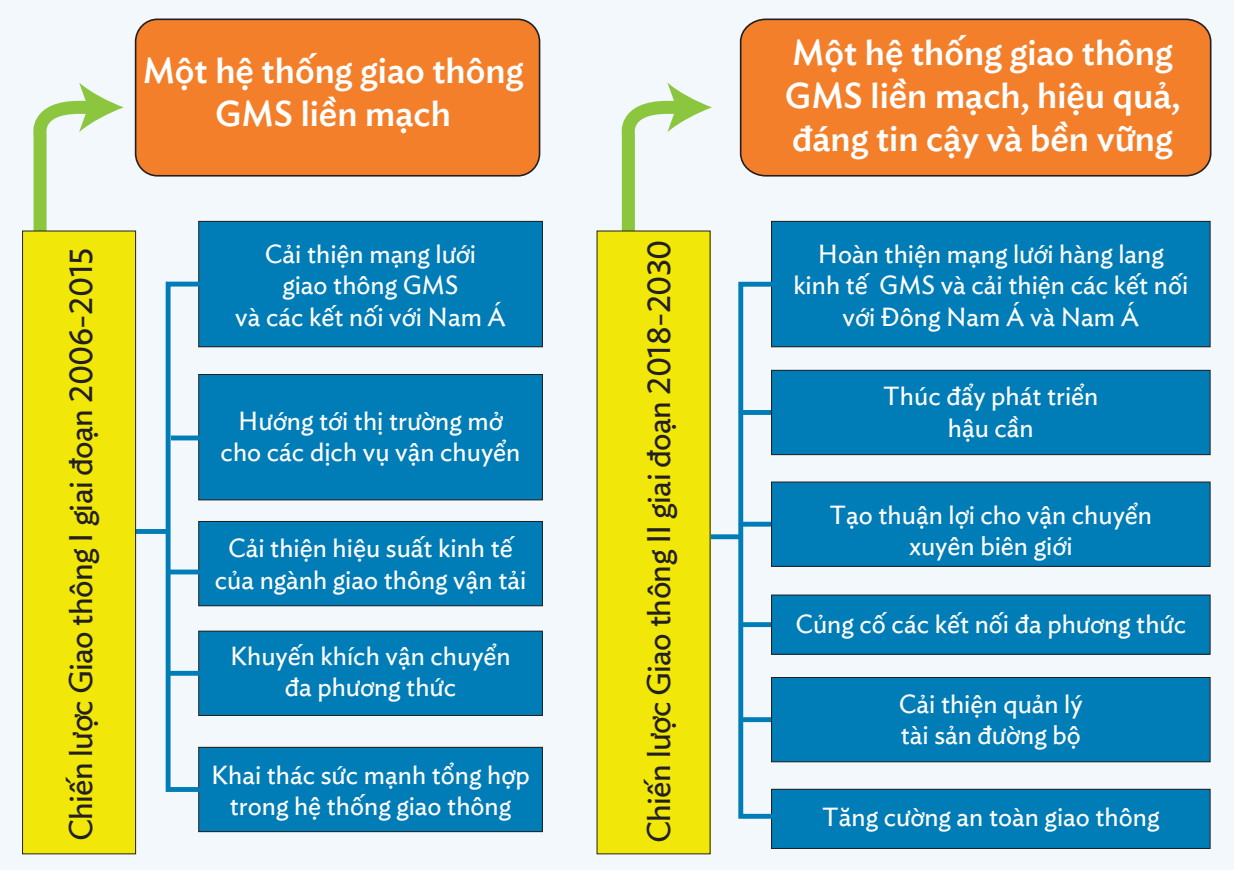

GMS = Tiểu vùng Mê-kông mở rộng

Nguồn: Theo ADB. 2017. Tài liệu GMS Transport Sector Strategy, 2018-2030, Manila; và ADB. 2006. Tài liệu GMS Transport Sector Strategy, 2006-2015. Manila.

(ii) Tạo thuận lợi cho vận chuyển xuyên biên giới. Điều này bao gồm việc tăng tốc và tăng cường triển khai $\mathrm{CBTA}$, với ưu tiên trước mắt là Chương trình Thu hoạch sớm liên quan đến việc cấp khoảng 500 giấy phép vận chuyển đường bộ trong GMS. Với các liên kết hành lang hầu hết đã hoàn thiện, việc tạo thuận lợi cho vận chuyển đã trở nên cấp thiết hơn để bắt kịp với những cải thiện về cơ sở hạ tầng vật chất và hiện thực hóa lợi ích từ đầu tư cơ sở hạ tầng.

(iii) Tăng cường kết nối vận chuyển liên phương thức. Tăng cường liên kết giữa các phương thức vận chuyển thông qua xây dựng "các chuỗi kết nối liên phương thức" (ví dụ: cải thiện kết nối giữa cảng - đường bộ - đường sắt), phản ánh một cách tiếp cận khác được thực hiện trong TrSS 2015, nhằm thúc đẩy cạnh tranh giữa các phương thức vận chuyển.

(iv) Thúc đẩy phát triển dịch vụ hậu cần. Phát triển dịch vụ hậu cần - như một bộ phận không thể tách rời của hệ thống cơ sở hạ tầng giao thông - sẽ được thúc đẩy bằng cách khuyến khích đầu tư vào các công trình liên quan đến vận tải và gia tăng giá trị, như các trung tâm hậu cần, kho bãi công-ten-nơ hoặc các cảng thông quan quốc tế, các tổ hợp cảng khô nội địa và kho lạnh; giúp phát triển nguồn nhân lực trong ngành hậu cần; và thúc đẩy hợp tác chặt chẽ hơn với khu vực tư nhân. Chiến lược hậu cần GMS sẽ được xây dựng để đẩy nhanh quá trình tích hợp các ngành công nghiệp vào các chuỗi giá trị khu vực và toàn cầu.

(v) Cải thiện quản lý tài sản đường bộ. Việc bảo trì các mạng lưới giao thông thường xuyên và đúng cách sẽ được thúc đẩy thông qua cách tiếp cận phối hợp trong tài trợ cho các 
chi phí bảo trì đường bộ, tăng cường hệ thống quản lý đường bộ, cải thiện công tác bảo trì đường bộ và tăng cường triển khai các hệ thống kiểm soát phương tiện quá tải.

(vi) Tăng cường an toàn giao thông đường bộ. Các tiêu chuẩn đường bộ chung sẽ được xây dựng trong những cấu phần quốc gia khác nhau của các hành lang $\mathrm{GMS}$, dựa trên các sáng kiến liên quan của Hiệp hội các Quốc gia Đông Nam Á, để đạt được mức độ hiệu quả, đáng tin cậy và bền vững phù hợp xuyên suốt các lãnh thổ của các quốc gia thành viên. Năng lực quản lý an toàn đường bộ, cũng như dữ liệu về hiệu quả và các biện pháp bảo đảm an toàn đường bộ cũng sẽ được thiết lập và triển khai.

Trong các chiến lược được đề cập ở trên, sẽ có các biện pháp được triển khai để thúc đẩy cơ sở hạ tầng và dịch vụ vận chuyển "thân thiện với môi trường", "khả năng chống chịu khí hậu" của các dự án giao thông dễ bị ảnh hưởng, và thiết lập các cơ chế quản lý rủi ro thiên tai và ứng phó khẩn cấp. Những mối quan tâm này phải được xem xét đầy đủ trong việc lập kế hoạch, thiết kế và triển khai các dự án giao thông GMS.

\section{Phát triển đô thị, các khu kinh tế cửa khẩu và các dự án không gian đa} ngành khác

Khung chiến lược Phát triển đô thị Tiểu vùng Mê-kông mở rộng giai đoạn 2015-2022 (UDSF) đang ở các giai đoạn đầu của quá trình xây dựng hoàn thiện, và các ưu tiên hoạt động cụ thể trong ba trụ cột của nó vẫn đang được hình thành (Hình 4). Các mũi nhọn chính của UDSF được dựa trên các trụ cột dưới đây:

(i) Trụ cột 1 , tập trung và việc quy hoạch và phát triển các trung tâm đô thị trọng điểm như một phần của khái niệm mở rộng về phát triển hành lang kinh tế;

(ii) Trụ cột 2 , tập trung vào các khu vực biên giới ưu tiên bên trong hệ thống các hành lang GMS tổng thể; và

(iii) Trụ cột 3 , tập trung vào xây dựng năng lực trong quy hoạch và quản lý đô thị, cũng nhu cải thiện sự phối hợp thể chế.

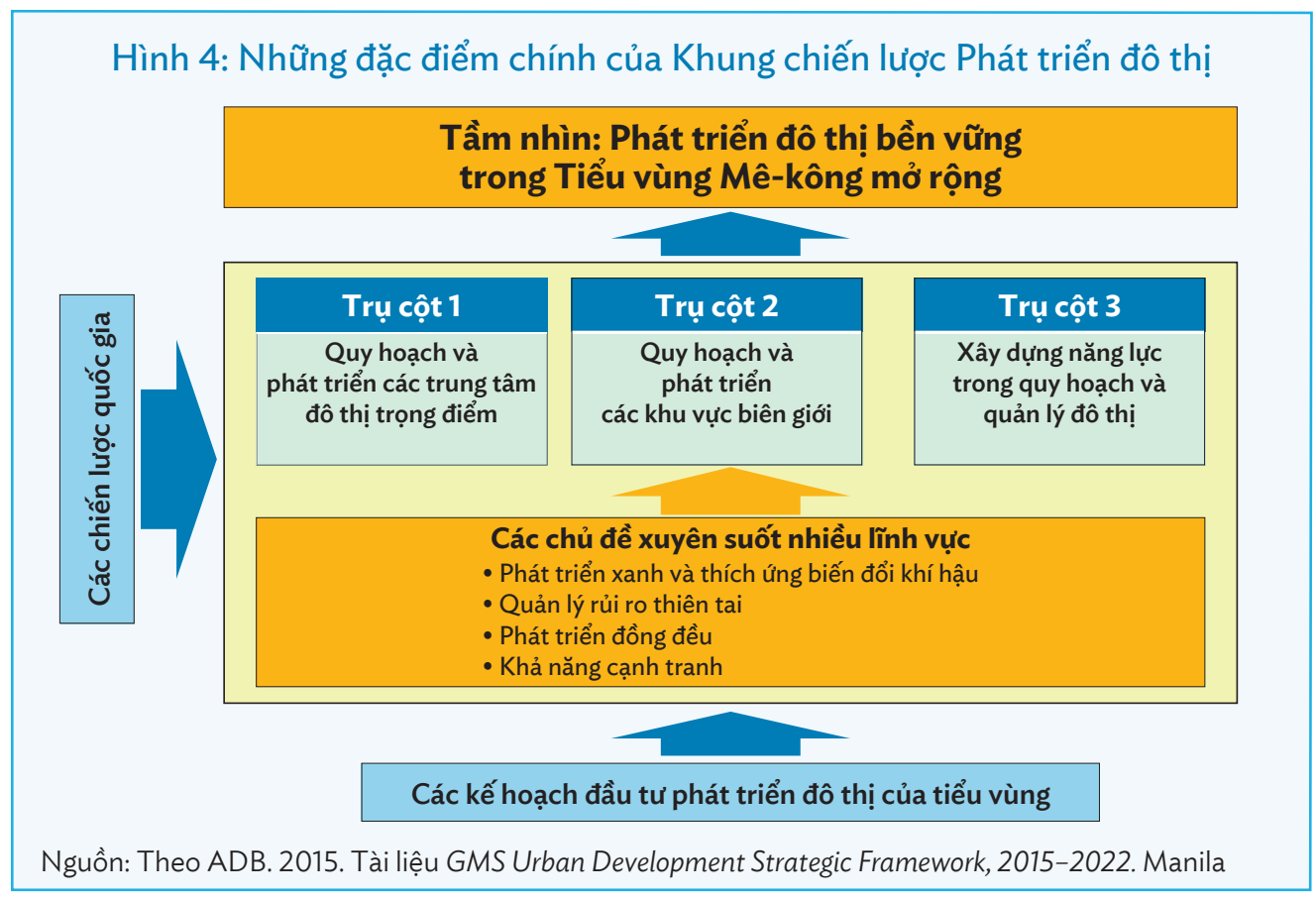


Việc vận hành các Trụ cột 1 và 2 trong HAP sẽ bao gồm xây dựng và áp dụng các tiêu chí lựa chọn để xác định những trung tâm đô thị và khu vực biên giới ưu tiên, và chuẩn bị các quy hoạch không gian để phát triển chúng. Tiêu chí để xác định các trung tâm đô thị trọng điểm sẽ đòi hỏi một cách tiếp cận rộng thay vì cứng nhắc, vì các thành phố và đô thị GMS rất đa dạng về quy mô, mật độ, đặc điểm và vai trò của chúng trong chiến lược phát triển quốc gia rộng hơn. Sẽ cần có một cách tiếp cận toàn diện, tập trung vào cả các cấu phần phần cứng và phần mềm. Cần có dữ liệu toàn diện và đáng tin cậy để xác định những đặc điểm và tiềm năng của các khu vực kinh tế; và quyết định các cấu trúc kinh tế và chức năng hoạt động, hiệu quả sử dụng đất, mật độ và mô hình di cư, bên cạnh những yếu tố khác. Xây dựng các chỉ số và biện pháp để theo dõi các yếu tố như tính cạnh tranh, "mức độ xanh", sự gắn kết xã hội và tính bền vững tổng thể sẽ rất quan trọng.

Để thúc đẩy các sáng kiến nói trên, sẽ cần xây dựng năng lực (Trụ cột 3) nhằm tăng cường năng lực phân tích trong quy hoạch đô thị và quản lý các hoạt động can thiệp đa ngành theo các thỏa thuận thể chế nhiều tầng phức tạp. Việc thúc đẩy chia sẻ tri thức (ví dụ: các trao đổi kỹ thuật ngang hàng) có thể giúp khám phá những cách tiếp cận phát triển đô thị bền vững của tiểu vùng trên cơ sở hợp tác. Chia sẻ tri thức mang đến khả năng phát triển các sáng kiến hơn nữa, ví dụ như trong lĩnh vực tăng trưởng đô thị xanh, vốn ngày càng trở nên quan trọng trong quy hoạch và phát triển đô thị.

\section{Năng lượng}

Hội nhập thị trường điện sẽ vẫn là chương trình nghị sự ưu tiên trong hợp tác năng lượng GMS.

Việc phát triển thị trường điện trong GMS áp dụng "cách tiếp cận khối hợp nhất" để xây dựng cơ sở hạ tầng kết nối lưới điện thiết yếu nhằm tạo thuận lợi về mặt công trình cho việc vận chuyển điện xuyên biên giới (Hình 5). Các quốc gia GMS đã đạt đến giai đoạn 1, với thương mại song phương đang diễn ra, và đang chuyển sang giai đoạn 2 với tiến độ hạn chế. Để có thêm tiến triển trong việc chuyển sang giai đoạn 2 , Trung tâm Điều phối Điện khu vực phải thực hiện vai trò quan trọng là thúc đẩy hoạt động đồng bộ của các hệ thống điện quốc gia hướng tới một thị trường điện khu vực thống nhất, công bằng và minh bạch, có thể đảm bảo cung cấp điện ổn định và đáng tin cậy với chi phí tiết kiệm nhất. Việc sử dụng các liên kết truyền tải của bên thứ ba cũng sẽ được xem xét triển khai. Để đặt nền tảng cho giai đoạn 3 , một quy hoạch tổng thể truyền tải điện khu vực sẽ được xây dựng làm cơ sở cho việc phát triển các liên kết truyền tải dành riêng cho thương mại xuyên biên giới.

Trong 5 năm tới, sẽ tiếp tục thúc đẩy thương mại điện khu vực (RPT) thông qua các hoạt động sau: (i) hài hòa hóa các tiêu chuẩn hiệu suất kỹ thuật khu vực GMS và phát triển các mã lưới, (ii) tạo ra một môi trường pháp lý thuận lợi để hỗ trợ thương mại điện khu vực ở mức cao hơn, (iii) nghiên cứu chuyên sâu về các mạng kết nối xuyên biên giới tiềm năng, (iv) thu hút sự tham gia của khu vực tư nhân vào các dự án RPT xuyên biên giới, và (v) đặt mục tiêu về tỉ trọng năng lượng tái tạo cao hơn trong quy hoạch các mạng lưới điện khu vực. Việc phát triển thị trường điện sẽ lồng ghép nhũng cân nhắc về môi trường trong thiết kế các quy hoạch mở rộng điện. Đánh giá môi trường chiến lược sẽ được sử dụng trong quy hoạch ngành điện và phát triển thủy điện. Sẽ tiếp tục tăng cường năng lực để thúc đẩy quản lý môi trường hiệu quả trong triển trai các dự án điện. 
Hình 5: Các giai đoạn trong thiết lập thị trường điện Tiểu vùng Mê-kông mở rộng

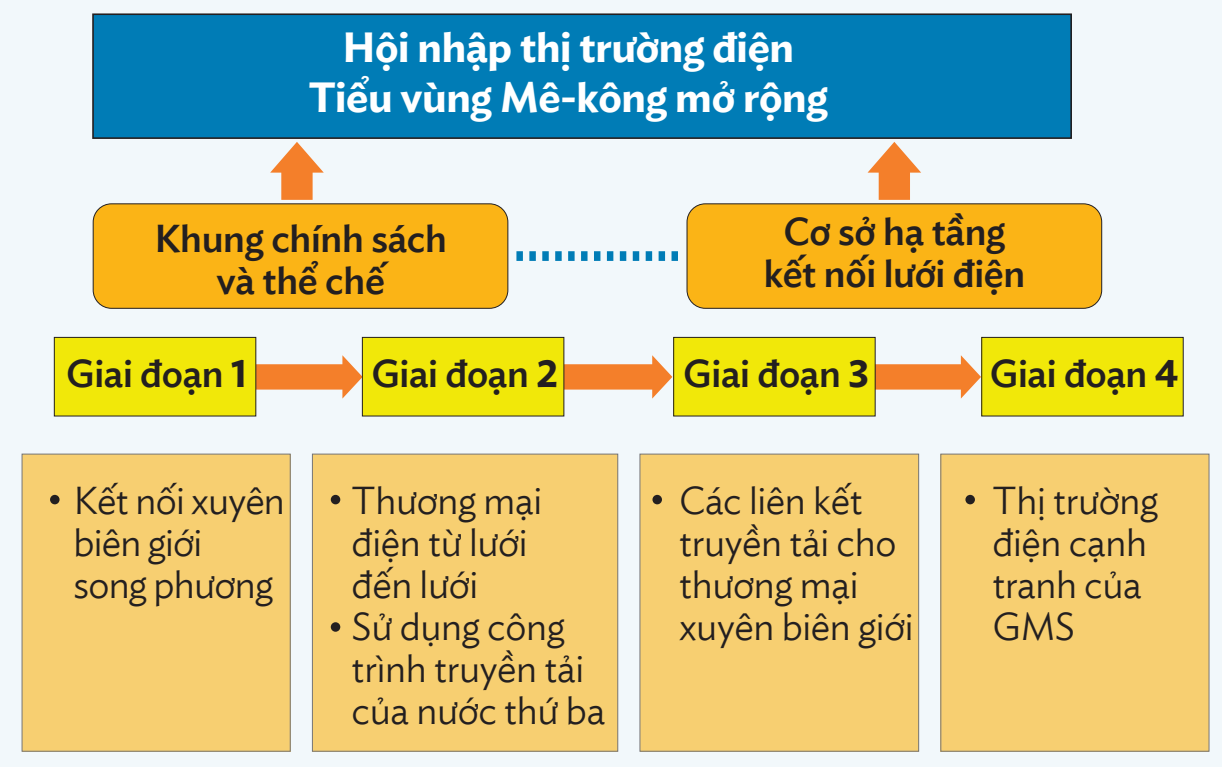

GMS = Tiểu vùng Mê-kông mở rộng.

Nguồn: Theo ADB. 2002. Tài liệu Energy Sector Strategy, GMS Strategic Framework 2012-2022.

Manila; và ADB. 2004. Tài liệu Regional Power Trade Operating Agreement Report. Manila.

\section{Nông nghiệp}

Chiến lược Thúc đẩy các Chuỗi giá trị dựa trên Nông nghiệp an toàn và thân thiện với môi trường trong Tiểu vùng Mê-kông mở rộng và Kế hoạch Hành động Siêm Riệp giai đoạn 20182022 (SASRAP) sẽ định hướng hợp tác GMS trong lĩnh vực nông nghiệp trong 5 năm tới. Về cơ bản, SASRAP là sự mở rộng Trụ cột 1 của Chương trình hỗ trợ Nông nghiệp cốt lõi Giai đoạn II 2011-2015 (sau này mở rộng đến năm 2020), tập trung vào xây dựng năng lực cạnh tranh toàn cầu bằng cách thúc đẩy an toàn thực phẩm và hiện đại hóa thương mại nông nghiệp thông qua các hệ thống và tiêu chuẩn hài hòa hóa (Hình 6). SASRAP nhằm mục tiêu tăng cường chú trọng tới xây dựng và vận động chính sách như một phương tiện để mở rộng sản xuất các sản phẩm nông nghiệp an toàn và thân thiện với môi trường (SEAP) thông qua cách tiếp cận chuỗi giá trị.

Tầm nhìn của SASRAP là đưa "GMS trở thành nhà cung cấp hàng đầu các sản phẩm nông nghiệp an toàn và thân thiện với môi trường trên toàn cầu". Tầm nhìn này được dựa trên lợi thế so sánh của GMS trong nông nghiệp, vốn có thể được phát huy mạnh mẽ thông qua cách tiếp cận tiểu vùng để tạo ra lợi thế kinh tế nhờ quy mô, gia tăng thương mại, và thúc đẩy an toàn thực phẩm mang tính bao trùm. Kết quả dự định là cải thiện tiếp cận thị trường cho các sản phẩm nông nghiệp an toàn và thân thiện với môi trường bằng cách thiết lập tiêu chuẩn an toàn thực phẩm GMS phù hợp với các tiêu chuẩn khu vực và quốc tế. Trọng tâm về an toàn thực phẩm bao quát việc áp dụng các công nghệ và thông lệ sản xuất nông nghiệp thân thiện với môi trường và khí hậu. 


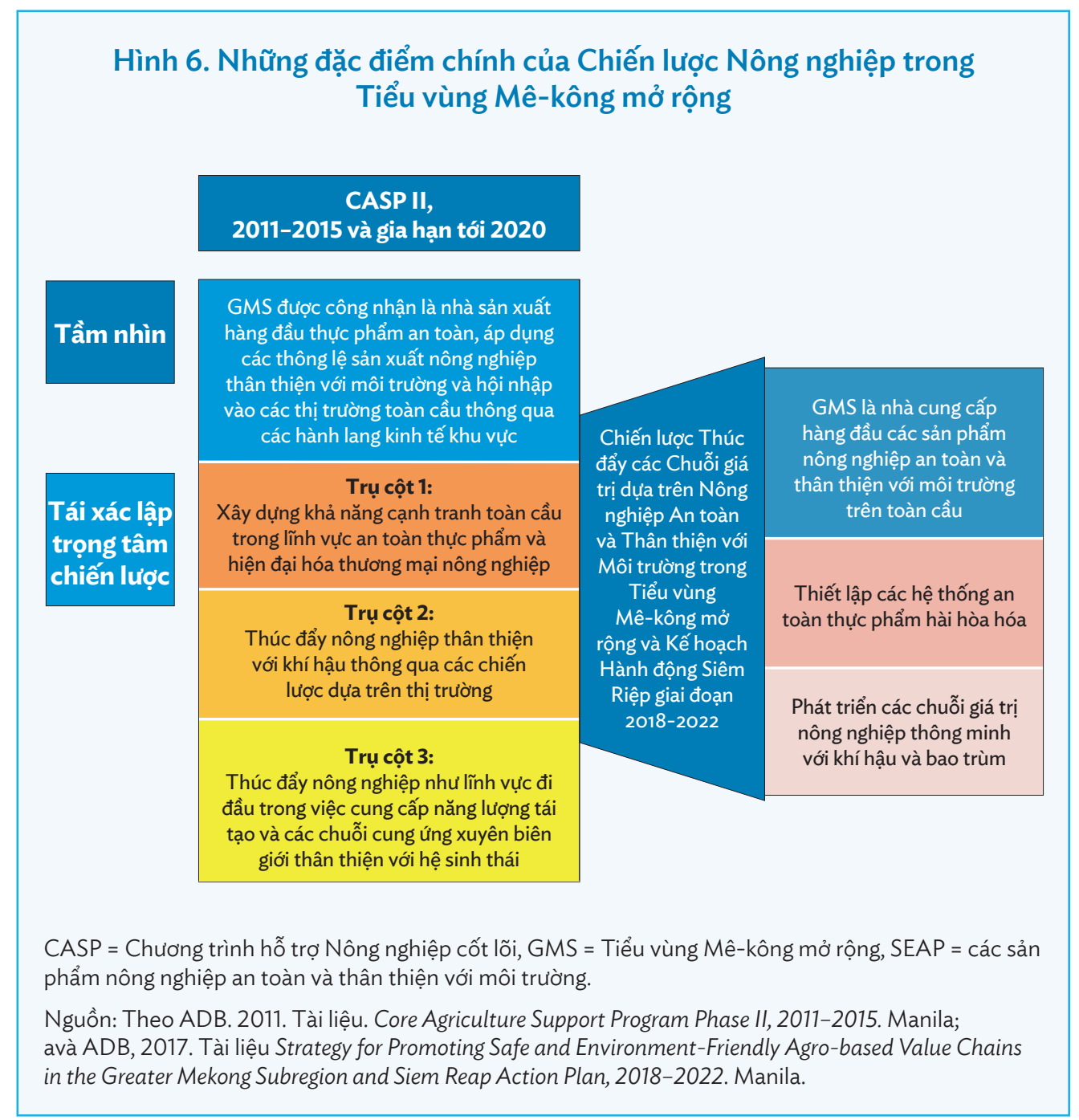

Các định hướng chiến lược và ưu tiên hoạt động của SASRAP là: (i) xây dựng các tiêu chuẩn, thông lệ và chính sách hài hòa hóa để tạo thuận lợi cho sản xuất, thương mại và đầu tư vào các chuỗi giá trị SEAP; (ii) tăng cường cơ sở hạ tầng cho các chuỗi giá trị SEAP tích hợp toàn khu vực; (iii) cải thiện các hệ thống để tạo ra, chia sẻ và phổ biến tri thức và sáng tạo liên quan đến các chuỗi giá trị SEAP; và (iv) xây dựng các phương pháp tiếp thị để thúc đẩy danh tiếng của GMS với tư cách nhà cung cấp hàng đầu SEAP trên toàn cầu. SASRAP nhấn mạnh các phương pháp tiếp cận sáng tạo, đa ngành và xuyên suốt nhiều lĩnh vực như: (i) thành lập các khu chế biến nông nghiệp và công viên thực nghiệm nông nghiệp giúp tạo thuận lợi cho sản xuất, chế biến và buôn bán SEAP, bao gồm xây dựng các khu kiểm soát dịch bệnh vật nuôi tại cửa khẩu; (ii) thành lập các cơ sở ướm tạo doanh nghiệp nông nghiệp, tập trung vào các doanh nghiệp khởi nghiệp đang phát triển và các doanh nghiệp vừa và nhỏ có tính sáng tạo; (iii) thiết lập mạng lưới các cơ sở giáo dục và đào tạo phục vụ việc nghiên cứu, giáo dục, nâng cao năng lực và các trung tâm thực nghiệm; và (iv) tập trung vào những sáng tạo có thể giúp giảm chi phí, đáp ứng sở thích của người tiêu dùng và cải thiện các hoạt động hậu cần nhằm tối đa hóa lợi thế kinh tế nhờ quy mô. 


\section{Môi trường}

Chương trình Môi trường then chốt (CEP) đã được triển khai tại các quốc gia GMS từ năm 2006 với tầm nhìn là đạt được một "Chương trình Hợp tác Kinh tế GMS thân thiện với môi trường và thích ứng khí hậu” (Hình 7). CEP được thiết kế sử dụng cách tiếp cận phân kỳ, bao gồm giai đoạn thử nghiệm (2006-2011), giai đoạn nhân rộng (2012-2017) và giai đoạn củng cố (2018-2022).

Trong giai đoạn củng cố, một Khung Chiến lược và Kế hoạch Hành động CEP mới trong giai đoạn 2018-2022 (CEP-SFAP) đã được xây dựng để củng cố và phát huy các thành tựu trong quá khứ, và giao việc tổ chức thực thi cho các nước. CEP-SFAP sẽ theo đuổi cách tiếp cận dịch vụ dựa trên hệ sinh thái thông qua số dự án ít hơn nhưng có tác động cao, và sẽ tập trung vào tính sẵn sàng của dự án khi hướng tới việc phân cấp triển khai CEP cho các quốc gia GMS. Trong khi đó, các cam kết toàn cầu gần đây đối với các Mục tiêu Phát triển Bền vững và Thỏa thuận Paris 2016 đã mang đến một cơ hội mới cho CEP để tái tập trung cách tiếp cận của mình nhằm cung cấp các dịch vụ tư vấn, kỹ thuật và dịch vụ liên quan đến dự án cho các quốc gia GMS.

Hình 7. Chuyển dịch chiến lược trong Chương trình Môi trường then chốt

\section{CEP I 2006-2011} Giai đoạn thí điểm

\section{CEP II 2011-2017 Giai đoạn nhân rộng}

CEP 2018-2022 Giai đoạn củng cố

\begin{tabular}{|c|c|c|}
\hline Hạng mục & CEP I và II, 2006-2017 & CEP-SFAP 2018-2022 \\
\hline Trọng tâm khu vực & $\begin{array}{l}\text { Các cảnh quan } \\
\text { xuyên biên giới quốc gia }\end{array}$ & $\begin{array}{l}\text { Các khu vực có giá trị dịch vụ hệ sinh } \\
\text { thái cao bên trong các hành lang kinh } \\
\text { tế GMS và các dự án trong danh mục } \\
\text { dự kiến đầu tư của RIF }\end{array}$ \\
\hline Cách tiếp cận & $\begin{array}{l}\text { Cách tiếp cận theo khu vực } \\
\text { địa lý đối với cảnh quan, các } \\
\text { ranh giới lưu vực }\end{array}$ & $\begin{array}{l}\text { Cách tiếp cận dịch vụ dựa trên hệ sinh } \\
\text { thái đối với cảnh quan trong ECP, RIF, } \\
\text { các khuôn khổ quốc tế }\end{array}$ \\
\hline Các dự án & Phạm vi rộng các dự án nhỏ & Ít dự án hơn nhưng có tác động lớn \\
\hline $\begin{array}{l}\text { Tư vấn kỹ thuật } \\
\text { và hỗ trợ } \\
\text { chính sách }\end{array}$ & $\begin{array}{l}\text { Các hoạt động thí điểm } \\
\text { riêng rẽ }\end{array}$ & $\begin{array}{l}\text { Các hệ thống quản lý môi trường } \\
\text { quốc gia }\end{array}$ \\
\hline Năng lực & Các cá nhân & $\begin{array}{l}\text { Các thể chế và tổ chức dựa trên } \\
\text { nhu câuu }\end{array}$ \\
\hline Trọng tâm tri thức & Các lĩnh vực chủ đề rộng & Tính sẵn sàng của dự án và phát triển \\
\hline Tài trợ & $\begin{array}{l}\text { Đồng tài trợ của các nhà } \\
\text { tài trợ thông qua các dự án } \\
\text { hỗ trợ kỹ thuật khu vực } \\
\text { của ADB }\end{array}$ & $\begin{array}{l}\text { Các dự án lớn được tài trợ bởi các } \\
\text { ngân hàng phát triển, khu vực tư', các } \\
\text { nhà tài trợ và thể chế tài trợ } \\
\text { Các dự án nhỏ hơn được ADB tài trợ }\end{array}$ \\
\hline
\end{tabular}

$\mathrm{ADB}=$ Ngân hàng Phát triển Châu Á, $\mathrm{CEP}=$ Chương trình Môi trường then chốt, $\mathrm{ECP}=$ Chương trình Hợp tác Kinh tế, GMS = Tiểu vùng Mê-kông mở rộng, RIF = Khung Đầu tư vùng, SFAP = Khung Chiến lược và Kế hoạch Hành động.

Nguồn: Chuyển thể từ ADB. 2017. Tài liệu Core Environment Program Strategic Framework and Action Plan, 2018-2022. Manila. 
CEP-SFAP sẽ tập trung vào ba lĩnh vực chủ đề ưu tiên: (i) công nghệ xanh và cơ sở hạ tầng bền vưng, (ii) dịch vụ hệ sinh thái và tài nguyên thiên nhiên, và (iii) khả năng thích ứng khí hậu và quản lý rủi ro thiên tai. Trong mỗi lĩnh vực ưu tiên này, chương trình sẽ hỗ trợ ba loại hình can thiệp có ảnh hưởng đến chu kỳ dự án đầu tư: (i) chuẩn bị đầu tư và tài trợ, (ii) quản lý tri thức và hấp thu công nghệ, và (iii) hoạch định chính sách và chiến lược. CEP sẽ tiếp tục ướm tạo và mở rộng quy mô các dự án môi trường được đưa vào RIF. Hỗ trợ tư vấn chính sách và tri thức sẽ bổ sung cho việc xây dựng và thực hiện các dự án đầu tư. CEP cũng đã điều chỉnh trọng tâm địa lý của mình hướng vào các hành lang kinh tế GMS và các dự án RIF.

\section{Du lịch}

Chiến lược Du lịch giai đoạn 2016-2025 (TSS II) dựa trên những thành tựu và giải quyết chương trình nghị sự còn dang dở của TSS I trong bối cảnh có những thay đổi đáng kể của thị trường du lịch (Hình 8). Trong khi các nỗ lực trước đây tập trung vào việc tăng lượng du khách đến, TSS II đã thay đổi chiến lược của mình theo hướng tạo ra doanh thu từ du lịch lớn hơn thông qua trải nghiệm có chất lượng và thời gian lưu trú lâu hơn của du khách. Chiến lược này cũng nhằm đạt mục tiêu phân phối rộng hơn các lợi ích của du lịch thông qua phát triển các điểm đến thứ cấp để giảm bớt mật độ du khách tập trung tại các điểm đến cửa ngõ. Điều này bao gồm cải thiện các sân bay trong nước, cảng nội địa và cảng biển cho du lịch tàu biển và tạo thuận lợi cho việc đi lại liền mạch bên ngoài các điểm đến cửa ngõ truyền thống. Công nghệ thông tin sẽ được khai thác để cung cấp thông tin tốt hơn cho sự lựa chọn của người tiêu dùng và phản hồi của các nhà cung cấp dịch vụ du lịch.

Phát triển nguồn nhân lực sẽ vẫn là một ưu tiên quan trọng, nhưng với trọng tâm lớn hơn dành cho dịch vụ và trải nghiệm có chất lượng. Đây là những vấn đề thiết yếu để bảo đảm khả năng cạnh tranh du lịch trong một thị trường du lịch đa dạng bị chi phối bởi thế hệ "thiên niên kỷ" (những người sinh ra trong giai đoạn từ năm 1980 tới 1998) đang tìm kiếm du lịch có trách nhiệm xã hội và người cao tuổi có nhiều thời gian hơn và có khả năng chi trả các dịch vụ cao cấp với nhiều nguồn lực hơn. Việc tuân thủ các tiêu chuẩn năng lực đối với người làm nghề du lịch (tiêu chuẩn nghề du lịch) của Hiệp hội các Quốc gia Đông Nam Á (ASEAN) và các tiêu chuẩn kỹ năng khu vực khác sẽ là động lực chính cho các sáng kiến phát triển nguồn nhân lực. Chúng sẽ bao gồm phát triển giáo dục, đào tạo và nâng cao năng lực liên quan đến ngành. Các sản phẩm du lịch đa quốc gia, cùng với quy hoạch và quản lý điểm đến tốt hơn sẽ được chú trọng hơn để thúc đẩy và đảm bảo trải nghiệm có chất lượng của du khách. Chất lượng cũng sẽ là nguyên tắc chi phối trong việc phát triển cơ sở hạ tầng và các dịch vụ môi trường như cung cấp nước sạch, an toàn và đáng tin cậy; nguồn năng lượng đáng tin cậy và sử dụng năng lượng hiệu quả; và quản lý nước thải và chất thải rắn thân thiện với môi trường.

TSS II có năm định hướng chiến lược giúp định hướng hợp tác du lịch GSM trong 5 năm còn lại của GMS SF-II và sau đó, bao gồm:

(i) phát triển nguồn nhân lực, tập trung vào triển khai các tiêu chuẩn kỹ năng khu vực (phù hợp với khung ASEAN), nâng cao năng lực cho các quan chức chính phủ, và hỗ trợ cho các doanh nghiệp du lịch;

(ii) cải thiện cơ sở hạ tầng du lịch bao gồm các sân bay, tiếp cận đường bộ tại các điểm đến thứ cấp, cơ sở hạ tầng đô thị xanh, cảng hành khách trên sông và cảng biển, và hệ thống đường sắt xuyên quốc gia;

(iii) nâng cao trải nghiệm của du khách và dịch vụ thông qua việc xây dựng các quy hoạch điểm đến tích hợp theo chủ đề và không gian, cũng như tạo ra những trải nghiệm đa 


\begin{tabular}{|c|c|c|c|}
\hline \multicolumn{4}{|c|}{ Hình 8. Tinh chỉnh các Chiến lược Du lịch trong Tiểu vùng GMS mở rộng } \\
\hline & \multicolumn{2}{|l|}{ TSS I 2011-2015 } & TSS II 2016-2025 \\
\hline & \multicolumn{3}{|c|}{ 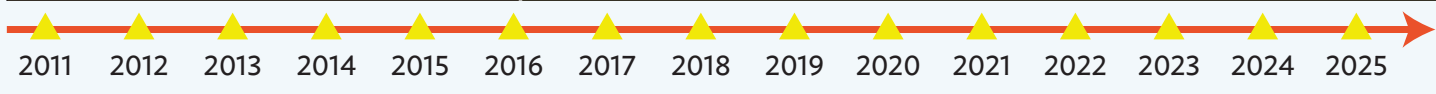 } \\
\hline Tầm nhìn & \multicolumn{2}{|c|}{$\begin{array}{l}\text { Cải thiện chất lượng sống phù hợp với } \\
\text { các Mục tiêu Phát triển Thiên niên kỷ } \\
\text { vể giảm nghèo, bình đẳng giới và trao } \\
\text { quyền cho phụ nữ, và bền vững về môi } \\
\text { trường }\end{array}$} & $\begin{array}{c}\text { Du lịch trong GMS có tính tổng hợp, mang lại sự thịnh vượng } \\
\text { đồng đều, có khả năng thích ứng, với các quan hệ đối tác hiệu } \\
\text { quả và quản lý tri thức }\end{array}$ \\
\hline $\begin{array}{l}\text { Trọng tâm } \\
\text { chiến lược }\end{array}$ & \multicolumn{2}{|l|}{$\begin{array}{l}\text { - Phân phối lợi ích kinh tế từ du lịch } \\
\text { trong GMS } \\
\text { - Góp phần vào phát triển bền vững, } \\
\text { bình đẳng giới và giảm nghèo }\end{array}$} & $\begin{array}{l}\text { - Thúc đẩy phát triển điểm đến mang tính cạnh tranh, cân bằng và bền vững } \\
\text { - Tạo ra và duy trì nguồn thu lớn hơn từ du lịch } \\
\text { - Tăng cường phân phối lợi ích công bằng bên trong và giữa các quốc gia GMS } \\
\text { - Kiểm soát những tác động tiêu cực về môi trường và xã hội }\end{array}$ \\
\hline $\begin{array}{l}\text { Sửa đổi - } \\
\text { Đặt lại } \\
\text { trọng tâm }\end{array}$ & \multicolumn{2}{|l|}{$\begin{array}{l}\text { - Tăng lượng du khách đến } \\
\text { - Phát triển các điểm đến chủ đạo } \\
\text { - Thúc đẩy vùng Mê-kông như một } \\
\text { điểm đến du lịch đơn nhất } \\
\text { - Xây dựng năng lực của nhân lực } \\
\text { ngành du lịch }\end{array}$} & $\begin{array}{l}\text { - Tăng cường trải nghiệm của du khách và chất lượng dịch vụ } \\
\text { - Phát triển các điểm đến thứ cấp } \\
\text { - Cải thiện quy hoạch nhiều điểm đến cho thời gian lưu trú dài hơn của } \\
\text { du khách } \\
\text { - Thực hiện đào tạo dựa trên năng lực cho nhân lực ngành du lịch gắn với } \\
\text { các tiêu chuẩn ASEAN }\end{array}$ \\
\hline
\end{tabular}

ASEAN = Hiệp hội các Quốc gia Đông Nam Á, GMS = Tiểu vùng Mê-kông mở rộng, HRD = phát triển nguồn nhân lực, MDGs = các Mục tiêu Phát triển thiên niên kỷ, TSS = Chiến lược Du lịch.

Nguồn: Theo ADB. 2011. Tài liệu Greater Mekong Subregion Tourism Sector Strategy, 2011-2015. Manila; và Văn phòng Điều phối Du lịch Mê-kông. 2017. Tài liệu Greater Mekong Subregion Tourism Sector Strategy, 2016-2025. Manila.

quốc gia theo chủ đề; thực hiện các tiêu chuẩn du lịch chung, tạo thuận lợi cho hoạt động đầu tư vào các điểm đến thứ cấp, và ngăn ngừa những tác động tiêu cực về mặt xã hội và môi trường;

(iv) tiếp thị và quảng bá sáng tạo, bao gồm thúc đẩy các trải nghiệm đa quốc gia theo chủ đề, định vị GMS như là điểm đến đa dạng ở châu Á, tăng cường các thỏa thuận tiếp thị hợp tác công - tư và nâng cao nhận thức về các cơ hội du lịch và tính bền vưng của ngành; và

(v) tạo thuận lợi cho du lịch trong khu vực, bao gồm vận động và thực thi thỏa thuận dịch vụ hàng không phù hợp với khuôn khổ ASEAN, khắc phục các lỗ hổng chính sách du lịch, cải thiện cơ sở vật chất và quản lý biên giới.

TSS II phù hợp chặt chẽ với Kế hoạch Chiến lược Du lịch ASEAN giai đoạn 2016-2025 - kế hoạch này có thời gian trùng với chu kỳ của TSS II và vượt ra ngoài năm kết thúc của GMS SF-II (2022). Nhiều sáng kiến khác nhau của TSS II đã hỗ trợ và gắn với các tiêu chuẩn du lịch ASEAN, tiêu chuẩn nghề du lịch, các thỏa thuận thừa nhận lẫn nhau về nghề du lịch, và chính sách bầu trời mở. Giống như TSS I cho giai đoạn 2011-2015, TSS II kế nhiệm cũng tập trung vào các hành lang kinh tế và tích hợp quy hoạch không gian, đặc biệt trong việc phát triển các trải nghiệm đa quốc gia theo 
chủ đề gắn với các cụm khu vực và các tuyến đường đi qua ít nhất hai nước. Các chương trình thăm quan du lịch đa quốc gia theo chủ đề ưu tiên sẽ nằm trong những đoạn hoặc phân đoạn của các hành lang kinh tế GMS với sự chú trọng đặc biệt vào các khu vực biên giới.

\section{Tạo thuận lợi thương mại}

Kế hoạch Hành động Tạo thuận lọi thương mại và giao thông giai đoạn 2015-2017 bao quát bốn lĩnh vực then chốt: (i) quyền vận chuyển và giao thông, (ii) đơn giản hóa và hiện đại hóa thủ tục hải quan, (iii) hỗ trợ tăng cường vận chuyển và hậu cần, và (iv) tăng cường năng lực cho các biện pháp vệ sinh và kiểm dịch động thực vật (SPS). Một số hoạt động trong các liñh vực then chốt này đã được thực hiện hoặc đang diễn ra, nhưng xét tới tính chất phức tạp của những cải cách pháp lý, sẽ cần thời gian để triển khai toàn diện các hoạt động đang diễn ra và các hoạt động khác theo kế hoạch.

Các cấu phần tạo thuận lợi giao thông trong Kế hoạch Hành động Tạo thuận lợi thương mại và giao thông giai đoạn 2015-2017 thuộc khuôn khổ Hiệp định Tạo thuận lợi vận chuyển xuyên biên giới hiện đang được bao quát bởi Chiến lược Giao thông 2030. Các cấu phần tạo thuận lợi thương mại trong kế hoạch hành động vẫn phù hợp và đang được triển khai, còn các hoạt động khác theo kế hoạch sẽ được chuyển sang giai đoạn còn lại của GMS SF-II. Việc tái kích hoạt Nhóm công tác Tạo thuận lợi Thương mại đã được dự trù để cung cấp động lực mới cho việc tiếp tục theo đuổi những lĩnh vực trọng tâm sau đây:

(i) hiện đại hóa hải quan dựa trên các tiêu chuẩn quốc tế và thông lệ tốt theo Công ước Kyoto sưa đổi; và áp dụng các hệ thống xử lý dựa trên công nghệ thông tin, kiểm soát và tuân thủ dựa trên rủi ro được định hướng bởi trí tuệ trong quan hệ đối tác với khu vực tư nhân;

(ii) đơn giản hóa và tiêu chuẩn hóa các tài liệu thương mại dựa trên các tiêu chuẩn quốc tế và tăng cường phối hợp giữa các cơ quan;

(iii) cải thiện quản lý biên giới có phối hợp, gồm tăng cường phối hợp giữa các cơ quan hải quan, các biện pháp SPS và các cơ quan quản lý biên giới khác theo thông lệ quốc tế tốt trong các hiệp định của Tổ chức Thương mại Thế giới, các tiêu chuẩn của Tổ chức Hải quan Thế giới và các khuôn khổ liên quan khác;

(iv) cải thiện các thỏa thuận thực thi SPS trong thương mại GMS bằng cách tăng cường năng lực về những công cụ quản lý cơ bản, như áp dụng cách tiếp cận dựa trên rủi ro, phối hợp giữa các cơ quan chính phủ, hợp tác với các ngành và cộng tác với các đối tác trong khu vực, và tăng cường tuân thủ các quy tắc SPS trong suốt chuỗi giá trị; và

(v) xây dựng cơ sở dữ liệu tạo thuận lợi thương mại và giao thông theo hành lang cụ thể nhằm cung cấp các chỉ số để đo lường hiệu quả về thương mại và vận chuyển của các hành lang kinh tế GMS.

\section{Phát triển nguồn nhân lực}

Khung Chiến lược và Kế hoạch Hành động Phát triển Nguồn nhân lực trong GMS giai đoạn 2013-2017 (SFAP) tập trung vào các biện pháp phát triển nguồn nhân lực mà sẽ tạo điều kiện thuận lợi cho quá trình hợp tác và hội nhập tiểu vùng; và vào những vấn đề xuyên biên giới liên quan đến hội nhập GMS (ví dụ: lây lan các bệnh truyền nhiễm, buôn người và buôn bán ma túy). SFAP đã xác định những mũi nhọn chiến lược sau cho từng tiểu ngành trong lĩnh vực phát triển nguồn nhân lực: (i) trong giáo dục, nâng cao năng lực giáo dục và đào tạo kỹ thuật và dạy nghề, và hợp tác trong giáo dục đại học; (ii) trong lao động, tạo điều kiện cho việc di cu lao động xuyên biên giới an toàn; và (iii) trong y tế, giải quyết các vấn đề y tế xuyên biên giới. SFAP cũng xác định những sáng kiến để giảm thiểu chi phí xã hội của việc phát triển các hành lang kinh tế GMS. 
Đánh giá giữa kỳ đã kết luận rằng ngoại trừ tiểu ngành y tế với tiến bộ đáng kể trong lĩnh vực kiểm soát bệnh truyền nhiễm, hợp tác tiểu vùng trong những tiểu ngành khác chỉ ở mức độ hạn chế (Hình 9).

Để duy trì động lực hợp tác trong lĩnh vực y tế, các quốc gia GMS đã thành lập một Nhóm công tác về Hợp tác $Y$ tế riêng rẽe, được giao nhiệm vụ xây dựng chiến lược ngành. Trong khi đó, các đối tác phát triển như Tổ chức Di cư quốc tế và Cơ quan Hợp tác quốc tế Đức đang xem xét tích hợp các sáng kiến GMS về lao động di cư và giáo dục và đào tạo kỹ thuật và dạy nghề trong các chương trình hiện tại của họ trong những lĩnh vực này. Chương trình nghị sự phía trước cho các tiểu ngành phát triển nguồn nhân lực vẫn chưa được xác định.

Hình 9: Những đặc điểm chính của Khung chiến lược và Kế hoạch hành động Phát triển nguồn nhân lực trong GMS giai đoạn 2013-2017

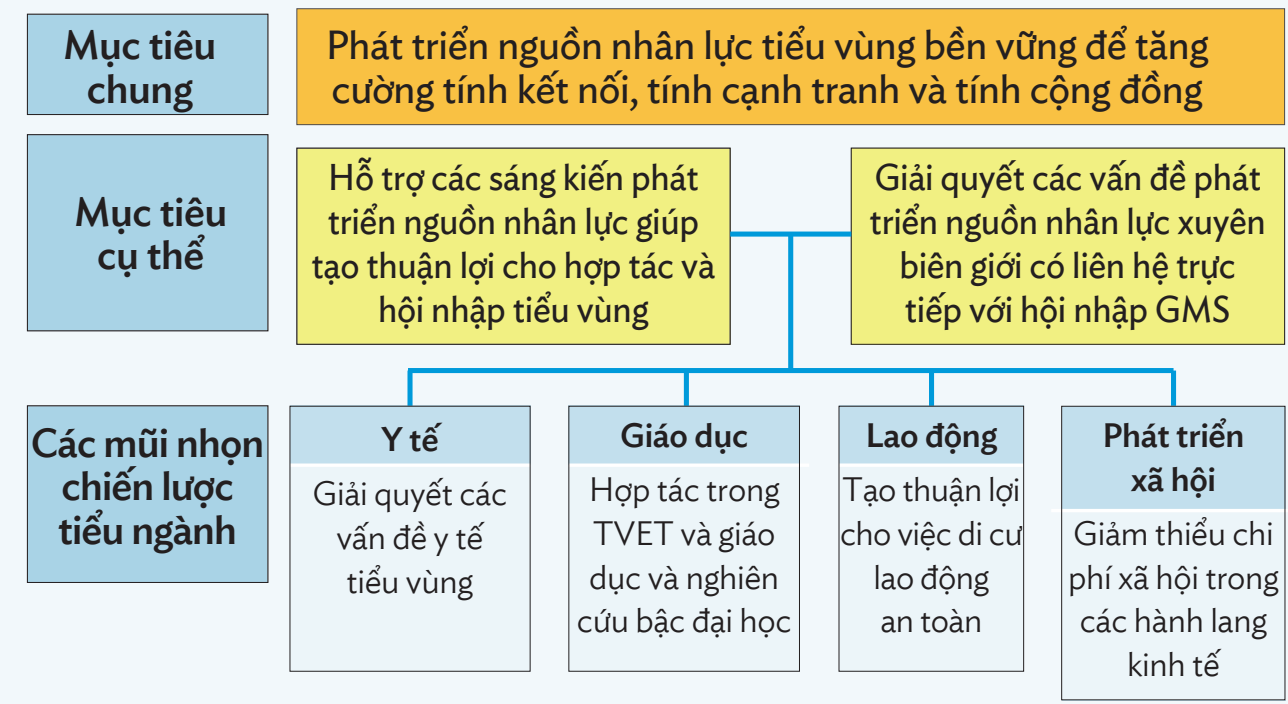

$\mathrm{HRD}$ = phát triển nguồn nhân lực, GMS = Tiểu vùng Mê-kông mở rộng, TVET = giáo dục nghề nghiệp.

Nguồn: Theo ADB. 2013. Tài liệu Strategic Framework and Action Plan for Human Resource Development in the Greater Mekong Subregion, 2013-2017, Manila.

\section{Công nghệ thông tin và truyền thông}

Hợp tác trong lĩnh vực công nghệ thông tin và truyền thông (CNTT) có thể được hồi sinh thông qua việc xây dựng khung chiến lược để cập nhật hoặc thay thế Khung Chiến lược Phát triển CNTT 2011 và thiết lập cơ chế thể chế để thực hiện chiến lược này. Chiến lược mới cần nêu bật vai trò quan trọng của CNTT trong thúc đẩy quá trình hội nhập GMS, đặc biệt là hỗ trợ thương mại và đầu tư, cũng như mở rộng thị trường thông qua các sản phẩm và dịch vụ tạo thuận lợi cho trao đổi thông tin. Chiến lược mới cũng cần làm giảm chi phí của hoạt động kinh doanh và các giao dịch liên quan đến thương mại. Các định hướng chiến lược trong hợp tác về CNTT có thể bao gồm nâng cao hỗ trợ chính sách và vận động chính sách cho CNTT; tăng cường các cấu trúc thể chế cho hợp tác xuyên biên giới về CNTT; phát triển nội dung, công cụ và các ứng dụng để chia sẻ thông tin; xây dựng năng lực và kết nối mạng lưới các chuyên gia về CNTT; thiết lập các 
dịch vụ hỗ trợ; và tăng cường vai trò của khu vực tư nhân trong phát triển CNTT. Chiến lược mới có thể củng cố vai trò hỗ trợ của ngành CNTT cho các ngành khác; xác định những cơ hội chiến lược và cụ thể (ví dụ: công nghệ xanh); và xác định các cơ chế phối hợp để hiện thực hóa cơ hội. Có thể huy động một nhóm đặc trách ban đầu để đề xuất phương hướng và các phương thức hợp tác CNTT trong tương lai ở GMS.

Cần tiếp tục thúc đẩy Nền tảng Thương mại điện tử GMS, cũng như khuyến khích các nhóm công tác GMS khám phá những cơ hội liên kết với Liên minh Doanh nghiệp GMS và các sáng kiến khác trong Nền tảng này. Đối với thương mại điện tử xuyên biên giới nói riêng, các chính phủ GMS có thể cân nhắc xây dựng các biện pháp chính sách liên quan đến an toàn dữ liệu, gian lận thương mại, quyền riêng tư và bảo vệ sở hữu trí tuệ. Các chính phủ GMS cũng có thể thúc đẩy sự sã̃n sàng tham gia thương mại điện tử của các doanh nghiệp bằng cách phát triển cơ sở hạ tầng liên quan đến CNTT nhằm giúp các công ty có thể truy cập mạng thông tin với chi phí thấp.

\section{Cải thiện các quy trình và hệ thống lập kế hoạch, xây dựng chương trình và giám sát}

Những cải thiện trong chu trình lập kế hoạch - xây dựng chương trình - giám sát Chương trình GMS sẽ được bắt đầu bằng việc áp dụng các hướng dẫn liên quan đến: (i) các khung thời gian chiến lược ngành liên quan đến khung thời gian chiến lược chung của Chương trình GMS; (ii) thiết lập các mục tiêu định lượng làm cơ sở cho việc xây dựng các chiến lược, chương trình và dự án; (iii) xây dựng khung giám sát kết quả và các quy trình và trách nhiệm thể chế để thực hiện nó; và (iv) vai trò của các Hội nghị Bộ trưởng, Hội nghị Quan chức cao cấp (SOM) và các nhóm công tác ở những giai đoạn khác nhau của chu trình lập kế hoạch.

Những cải tiến trong phạm vi, nguyên tắc và quy trình của Khung Đầu tư vùng (RIF) sẽ được thực hiện để đảm bảo rằng chúng hỗ trợ các ưu tiên hoạt động của Kế hoạch Hành động Hà Nội (HAP). RIF sẽ đưa ra một phạm vi các chương trình và dự án bao quát rộng hơn, gồm cả các dự án được hỗ trợ bởi các chính phủ GMS, Ngân hàng Phát triển Châu Á và các đối tác phát triển khác; và cụ thể hóa một hệ thống theo dõi tiến độ và cập nhật thường xuyên gắn với chu kỳ lập kế hoạch và xây dựng chương trình GMS tổng thể.

Một cách tiếp cận huy động nguồn lực có hệ thống hơn sẽ được triển khai để đáp ứng các yêu cầu tài chính của RIF, bao gồm quan hệ đối tác với các đối tác phát triển mới và các thể chế tài chính, cũng như với khu vực tư nhân thông qua quan hệ đối tác công tư và các thỏa thuận tương tự. Với vai trò nhà tài trợ chính, Ngân hàng Phát triển Châu Á sẽ chủ trì nỗ lực này và cũng sẽ hỗ trợ các quốc gia GMS sắp xếp hợp lý các dự án RIF để khiến chúng trở nên hấp dẫn hơn đối với các nguồn tài trợ.

Giám sát kết quả sẽ là ưu tiên quan trọng trong 5 năm tới của GMS SF-II. Các nhóm công tác của từng ngành sẽ chịu trách nhiệm thiết lập khung giám sát kết quả tương ứng gắn với chiến lược của ngành. Điều này sẽ bao gồm việc thiết lập các mục tiêu cụ thể, có thể đo lường, có thể đạt được, phù hợp và có thời hạn; xây dựng các chỉ số; thiết lập các mốc chuẩn và thu thập dữ liệu cần thiết. Hội nghị Quan chức cao cấp, nơi nghe báo cáo của các nhóm công tác, sẽ giám sát quá trình giám sát kết quả thông qua một hệ thống báo cáo thường xuyên. 


\section{E. Cải tiến những sắp xếp thể chế và quan hệ đối tác}

Kế hoạch Hành động Hà Nội (HAP) sẽ được thực hiện với những sắp xếp thể chế hiện thời. Tuy nhiên, dự kiến rằng những cải tiến trong khuôn khổ và các quy trình thể chế theo khuyến nghị của đánh giá giữa kỳ sẽ được cân nhắc và triển khai nhằm nâng cao hiệu quả và hiệu suất của các hoạt động trong Chương trình GMS. Những khuyến nghị này bao gồm:

(i) trao quyền cho các ban thư ký quốc gia chịu trách nhiệm cao hơn trong việc điều phối các giai đoạn của chu kỳ dự án ở cấp ngành;

(ii) chỉ định một người đứng đầu hoặc điều phối viên quốc gia cho các nhóm công tác ngành;

(iii) cho phép sự linh hoạt trong thiết lập các thỏa thuận thể chế bên ngoài các cấu trúc chính thức (các nhóm chuyên gia lâm thời, mạng lưới làm việc, trao đổi ngang hàng); và

(iv) tăng cường vai trò của Hội nghị Quan chức cao cấp với tư cách là cơ quan giám sát và điều phối các nhóm công tác.

Khi xem xét những cải tiến thể chế này, điều quan trọng là phải tính đến trình độ năng lực kỹ thuật và quản lý khác nhau giữa các ngành và năng lực khác nhau ở từng quốc gia; cũng như những thiếu hụt về kỹ năng và các hoạt động hỗ trợ xây dựng năng lực đề xuất. Cũng cần cân nhắc khả năng sẵn có nguồn lực (tài chính và nhân sự), lưu ý rằng các quốc gia GMS có trình độ phát triển kinh tế khác nhau, và cũng rất khác nhau trong ưu tiên hợp tác khu vực của mình.

Cần xây dựng các cơ chế thể chế cho chiến lược không gian GMS. Thiết kế phù hợp cho các cơ chế này có thể được xác định trong quá trình chuẩn bị các quy hoạch tổng thể, xét tới sự điều chỉnh cần thiết dựa trên bối cảnh đặc trưng của các khu vực cụ thể - năng lực thể chế, mức độ tự chủ của địa phương, và mức độ cam kết của các bên liên quan, bên cạnh nhiều yếu tố khác. Sẽ cần những cơ chế sáng tạo và đáp ứng trong mối quan hệ với các bên liên quan khác nhau ở cấp quốc gia, tiểu bang hoặc tỉnh và địa phương, bên cạnh các nhóm ngành công nghiệp và các tổ chức tư nhân khác (ngân hàng, trường học, bệnh viện) dựa trên vai trò của họ trong việc thiết kế, thực hiện và giám sát các dự án đa ngành định hướng không gian.

Có thể cải thiện hơn nữa quan hệ đối tác với khu vực tư nhân bằng cách thúc đẩy sự tham gia của họ ở cấp độ nhóm công tác và trong các sáng kiến cụ thể. Ngoài các cấu trúc thể chế chính thức của GMS, Chương trình GMS có thể cung cấp các diễn đàn nơi khu vực tư nhân có thể chia sẻ các ý tưởng, cách tiếp cận và giải pháp cho những thách thức phát triển cụ thể như phi các-bon hóa sản xuất công nghiệp và phát triển cơ sở hạ tầng thân thiện về sinh thái và có trách nhiệm về xã hội. Xét tới mục tiêu chung của các quốc gia GMS là tăng cường sự tham gia vào các chuỗi giá trị toàn cầu, có thể thúc đẩy các mạng lưới kinh doanh chuỗi cung ứng tiểu vùng hoặc các cụm công nghiệp. Có thể khuyến khích đầu tư tư nhân vào các chuỗi cung ứng, các đặc khu kinh tế và khu công nghiệp được thành lập tại biên giới hoặc dọc theo các hành lang. Có thể tìm hiểu những cơ chế đối tác công tư mới trong lĩnh vực y tế và giáo dục, và không chỉ trong các dự án cơ sở hạ tầng.

Các đối tác phát triển đã tích cực tham gia và đóng góp đáng kể cho Chương trình GMS, đặc biệt ở cấp độ các nhóm công tác của ngành. Có thể ghi nhận đóng góp của họ bằng cách đưa các dự án mà họ đang hỗ trợ vào trong RIF. Gần đây, các đối tác phát triển đã thể hiện sự quan tâm tới việc hỗ trợ phát triển khu vực tư nhân và các hiệp hội ngành nghề. Thúc đẩy quan hệ đối tác giữa khu vực tư nhân GMS và hiệp hội ngành nghề ở các nước thú ba là một lĩnh vực có thể được khai thác. 


\section{F. Bảo đảm thực hiện thành công Kế hoạch Hành động Hà Nội giai đoạn 2018-2022}

Sẽ có một số yếu tố quyết định mức độ thành công của kết quả đạt được trong HAP. Những yếu tố này phải được khai thác, quản lý và lồng ghép một cách có ý thức trong quá trình triển khai HAP để chúng trở thành "nhân tố tạo thuận lợi" cho việc đạt được mục tiêu (Hình 10). Những "nhân tố tạo thuận lợi này" bao gồm: (i) tạo sự đồng vận với Hiệp hội các Quốc gia Đông Nam Á và các sáng kiến khu vực khác, (ii) thu hút sự tham gia hiệu quả của khu vực tư nhân, (iii) nhũng cách tiếp cận mới trong thiết kế dự án và sắp xếp thể chế, (iv) các quy trình được hỗ trợ bởi công nghệ, và (v) kết nối và vận dụng tri thức.

(i) Sự đồng vận với Hiệp hội các Quốc gia Đông Nam Á và các sáng kiến khu vực khác. Phát huy lợi thế so sánh của Chương trình GMS (ví dụ: dựa trên hoạt động và định hướng kết quả) với các khung dựa trên chính sách của ASEAN có thể tạo ra sự đồng vận tích cực đáng kể trong các can thiệp phần cứng và phần mềm ở những ngành hoặc khu vực then chốt. Khai thác sự bổ sung lẫn nhau và xây dựng sự đồng vận với các sáng kiến quan trọng khác trong khu vực - như Sáng kiến Vành đai và Con đường và những sáng kiến khu vực của các đối tác phát triển khác - có thể mang lại cơ hội lớn hơn cho GMS. Những liên kết với các sáng kiến khác trong khu vực, đặc biệt là dựa hợp tác giữa các nền kinh tế địa phương, cũng có thể giúp thúc đẩy sự gắn kết giữa phát triển khu vực và địa phương.

Hình 10: Những nhân tố tạo thuận lợi của Kế hoạch Hành động Hà Nội

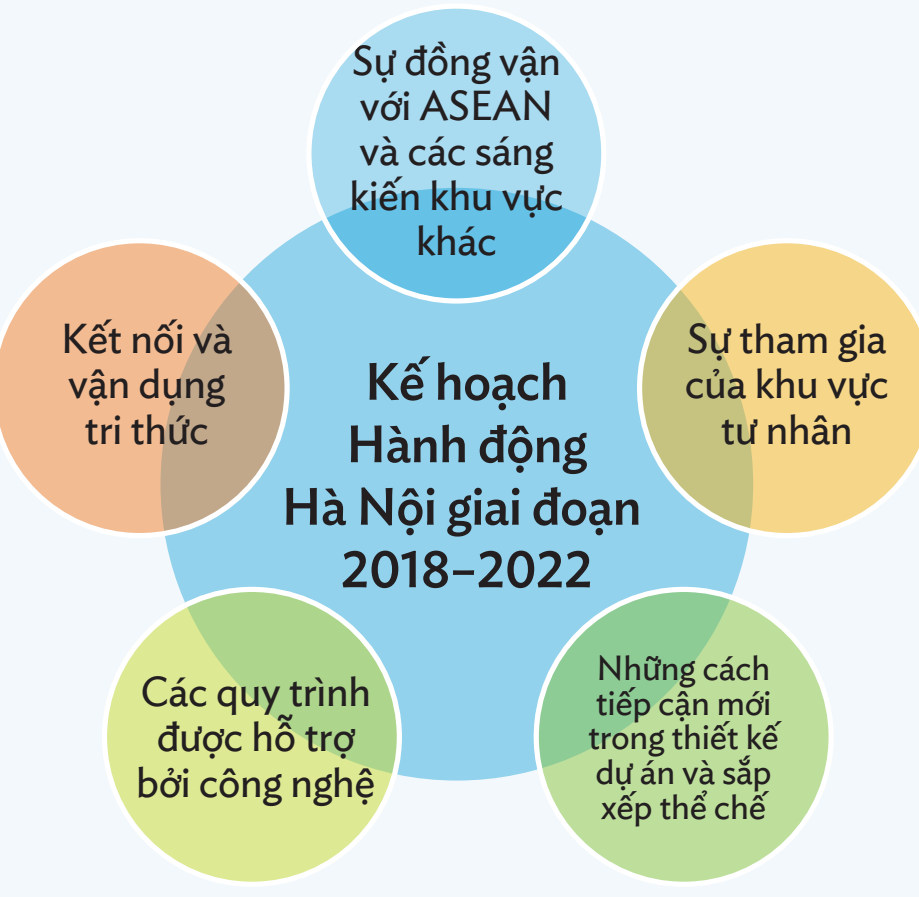

ASEAN = Hiệp hội các Quốc gia Đông Nam Á.

Nguồn: Ngân hàng Phát triển Châu Á 
(ii) Sự tham gia hiệu quả của khu vực tư nhân. Khu vực tư nhân đóng vai trò quan trọng trong khởi nghiệp kinh doanh, đa dạng hóa kinh tế, tạo việc làm và cung cấp hàng hóa và dịch vụ, từ đó góp phần vào tăng trưởng kinh tế và cải thiện chất lượng cuộc sống. Trong GMS, có rất nhiều cơ hội cho sự tham gia đầy đủ hơn của khu vực tư nhân, xét tới những chiến lược gần đây nhằm tạo sự đồng nhất ngày càng tăng giữa kết nối vật lý với kết nối thị trường, những cải cách sâu rộng để tự do hóa các thị trường hàng hóa và dịch vụ, cũng như tiến triển hướng tới hội nhập kinh tế trong khu vực.

(iii) Những cách tiếp cận mới trong thiết kế dự án và sắp xếp thể chế. Những đổi mới trong xây dựng chương trình và dự án thúc đẩy sự tham gia lớn hơn của các bên liên quan đã giúp gia tăng nhận thức, quyền làm chủ và cam kết mạnh mẽ hơn. Thông tin, tham vấn, hợp tác và trao quyền là các mức độ tham gia khác nhau giúp nâng cao hiệu quả và mang lại kết quả. Những dự án sáng tạo có thể được thí điểm và nhân rộng nếu được chứng minh thành công.

(iv) Các quy trình được hỗ trợ bởi công nghệ. Các quy trình được hỗ trợ bởi công nghệ có thể thúc đẩy hiệu suất trong các hoạt động kinh doanh. Hội nghị truyền hình, các ứng dụng di động để chia sẻ và truy cập thông tin, cơ sở dữ liệu dự án tương tác, bộ công cụ trực tuyến, thông tin trực tuyến và học tập trực tuyến nằm trong số những nền tảng dựa trên công nghệ có thể được giới thiệu và sử dụng ngày càng rộng rãi khi triển khai các hoạt động của GMS.

(v) Kết nối và vận dụng tri thức. Khi GMS chuyển sang các hoạt động hỗ trợ đa ngành và can thiệp phần mềm phức tạp hơn, hoạt động phân tích chất lượng cao và những diễn đàn hiệu quả để xây dựng sự đồng thuận trong công việc này sẽ ngày càng trở nên quan trọng. Hoạt động phân tích định hướng ngành sẽ phải được bổ sung bằng các quy hoạch đa ngành toàn diện. Một số nhóm công tác đã bắt đầu xây dựng các cơ sở dư liệu tập trung (ví dụ: nông nghiệp, phát triển đô thị và du lịch), và khả năng liên kết giữa những cơ sở dữ liệu này là rất quan trọng để tăng cường việc ứng dụng và sử dụng chúng trong quy hoạch đa ngành. 



\section{PHỤ LỤC: CÁC ƯU TIÊN HOAT ĐộNG THEO NGÀNH TRONG KẾ HOACH HÀNH ĐộNG HÀ NộI GIAI ĐOẠN 2018-2022}

$\mathrm{D}$ anh mục đề xuất dự án của vùng được đưa vào trong Khung Đầu tư vùng (RIF) 2022. Những hành động chính của Kế hoạch Hành động Hà Nội (HAP) sẽ cung cấp một khuôn khổ gắn kết và mạch lạc cho việc xây dựng dự án trong RIF 2022. Ở giai đoạn ban đầu, một số hành động mới của HAP có thể không nhất thiết được hỗ trợ bởi các dự án trong RIF 2022. Tuy nhiên, sẽ có sự nhất quán và liên kết chặt chẽ hơn giữa các hành động chính của HAP và những cập nhật tiếp theo của RIF 2022.

Bảng: Kế hoạch Hành động Hà Nội giai đoạn 2018-2022 - Các ưu tiên hoạt động theo ngành

\begin{tabular}{|c|c|}
\hline Các ưu tiên hoạt động theo ngành & Các hành động chính \\
\hline \multicolumn{2}{|l|}{ Giao thônga } \\
\hline 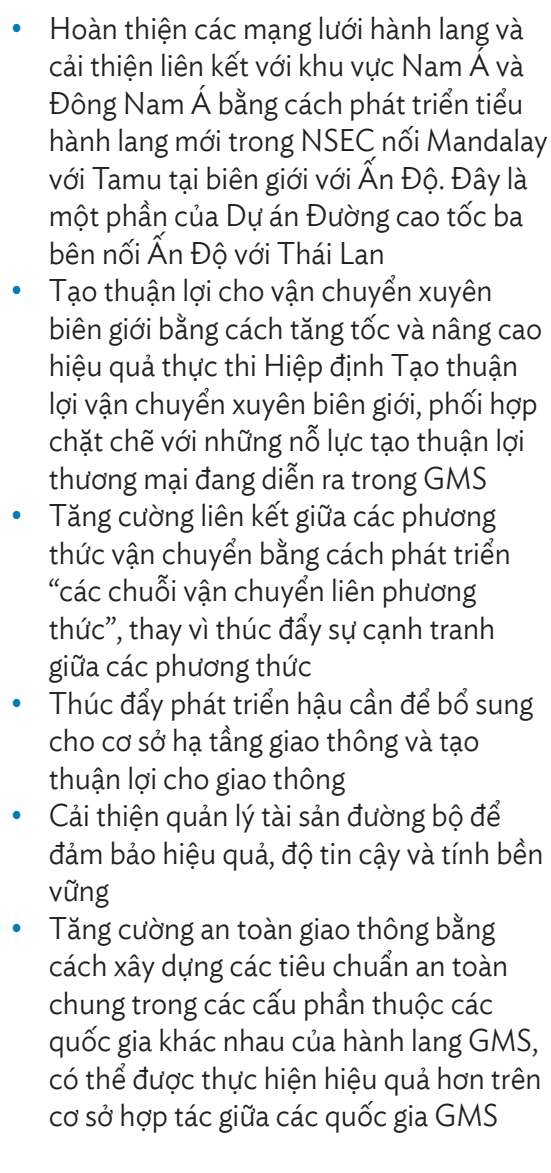 & 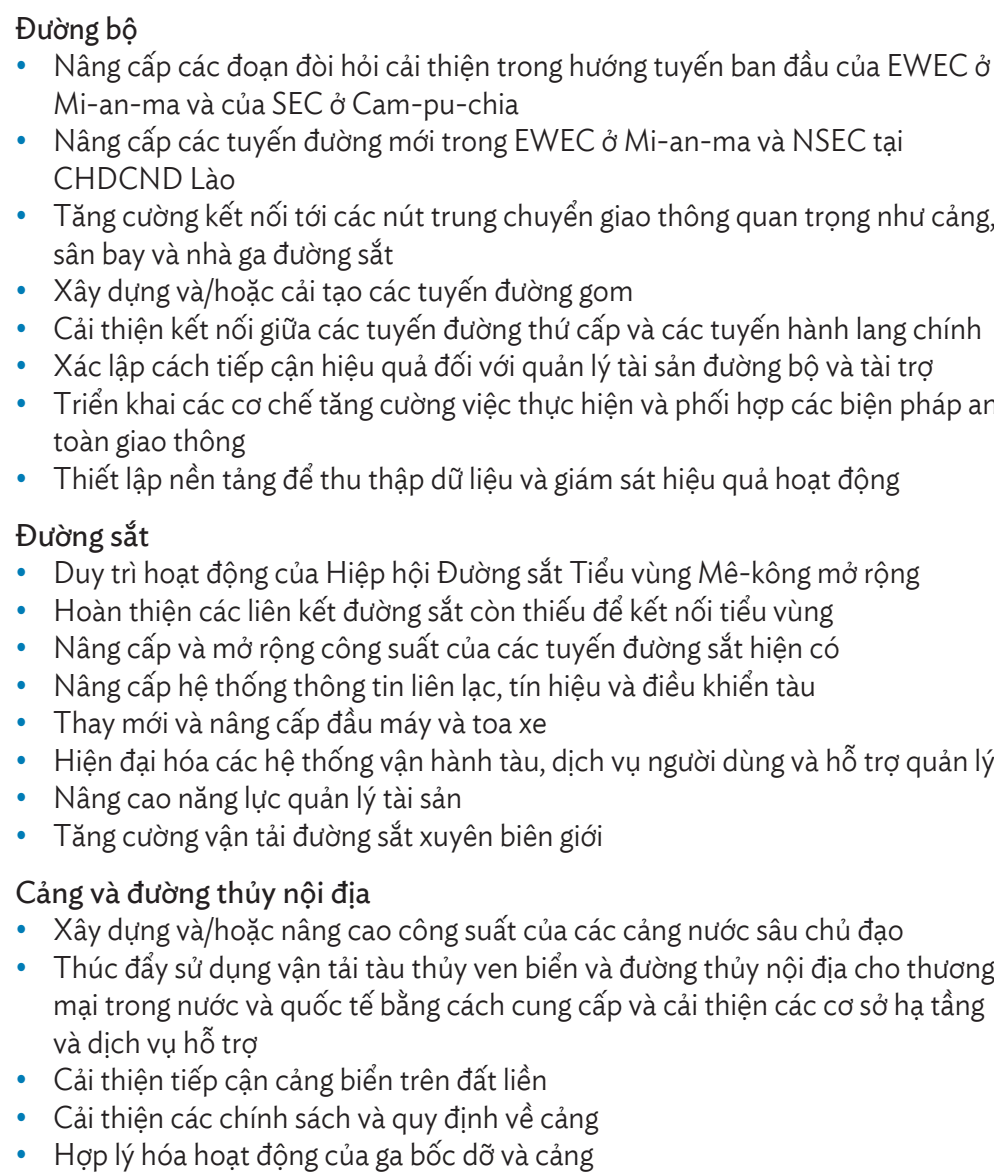 \\
\hline
\end{tabular}




\begin{tabular}{|c|c|}
\hline Các ưu tiên hoạt động theo ngành & Các hành động chính \\
\hline & 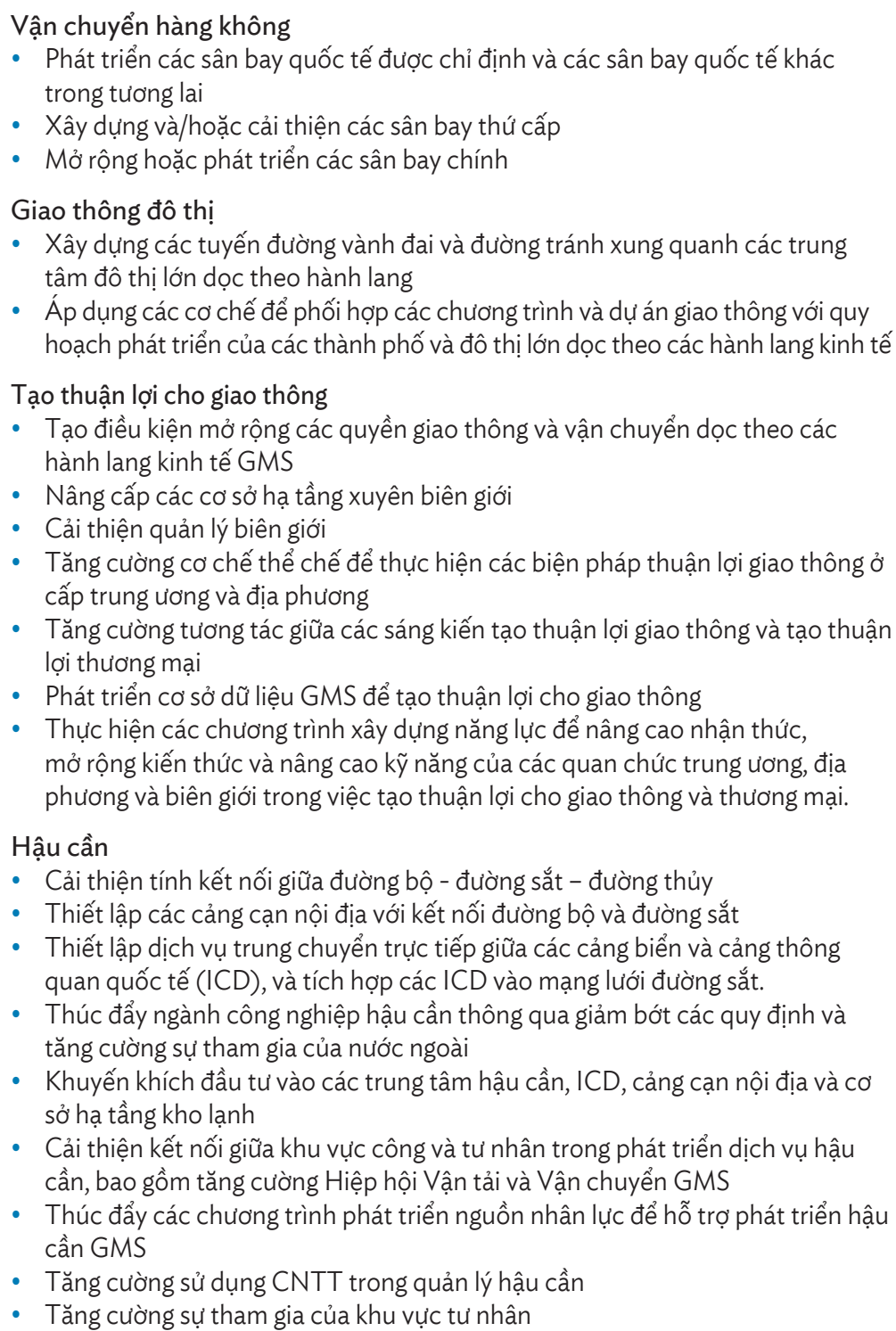 \\
\hline \multicolumn{2}{|c|}{ Phát triển đô thị, các lĩnh vực đa ngành và các Khu kinh tế cửa khẩu } \\
\hline $\begin{array}{l}\text { - Quy hoạch và phát triển các trung tâm } \\
\text { đô thị và khu vực biên giới trọng điểm, } \\
\text { sử dụng cách tiếp cận toàn diện và theo } \\
\text { khu vực, tập trung vào các hệ thống đô } \\
\text { thị như một phần của quy hoạch không } \\
\text { gian cho các hành lang kinh tế. }\end{array}$ & $\begin{array}{l}\text { - Xác định các trung tâm đô thị trọng điểm dọc theo các hành lang GMS và các } \\
\text { hệ thống đô thị } \\
\text { - Xây dựng các quy hoạch không gian đa ngành cho các đô thị được ưu tiên cao } \\
\text { - Cung cấp và nâng cấp cơ sở hạ tầng tại các đô thị hành lang GMS và các đô } \\
\text { thị trọng điểm khác } \\
\text { - Xác định hoắc cập nhật các khu vực biên giới trọng điểm và cửa khẩu ưu tiên } \\
\text { dựa trên nhứng hành lang kinh tế GMS đã được điểu chỉnh } \\
\text { - Xây dựng các quy hoạch không gian đa ngành cho các khu vực biên giới ưu tiên } \\
\text { - Phát triển các khu kinh tế cửa khẩu }\end{array}$ \\
\hline
\end{tabular}


Tiếp theo

\begin{tabular}{|c|c|}
\hline Các ưu tiên hoạt động theo ngành & Các hành động chính \\
\hline $\begin{array}{l}\text { - Xây dựng năng lực trong quy hoạch và } \\
\text { quản lý đô thị }\end{array}$ & 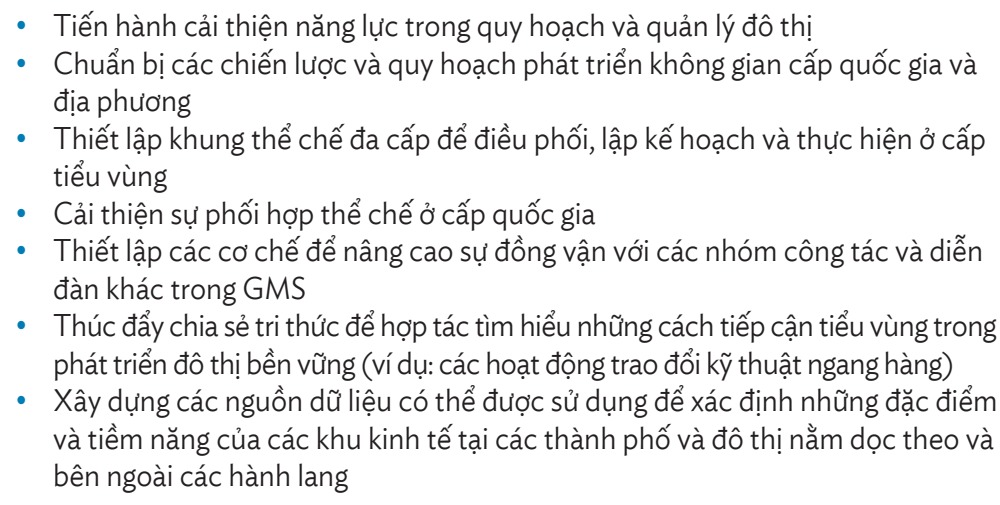 \\
\hline \multicolumn{2}{|l|}{ Năng lượngc } \\
\hline $\begin{array}{l}\text { - Tiếp tục phát triển thị trường điện khu } \\
\text { vực bằng cách xây dựng cơ sở hạ tầng kết } \\
\text { nối lưới điện và cung cấp khung chính } \\
\text { sách và thể chế cho việc mua bán điện: } \\
\text { - Giai đoạn 1: Kết nối xuyên biên giới } \\
\text { song phương } \\
\text { - Giai đoạn 2: Thương mại điện trên } \\
\text { lưới giữa hai quốc gia GMS bất kỳ } \\
\text { - Giai đoạn 3: Liên kết truyền tải điện } \\
\text { cho thương mại xuyên biên giới } \\
\text { - Giai đoạn 4: Thị trường năng lượng } \\
\text { cạnh tranh khu vực GMS tích hợp } \\
\text { hoàn thiện }\end{array}$ & 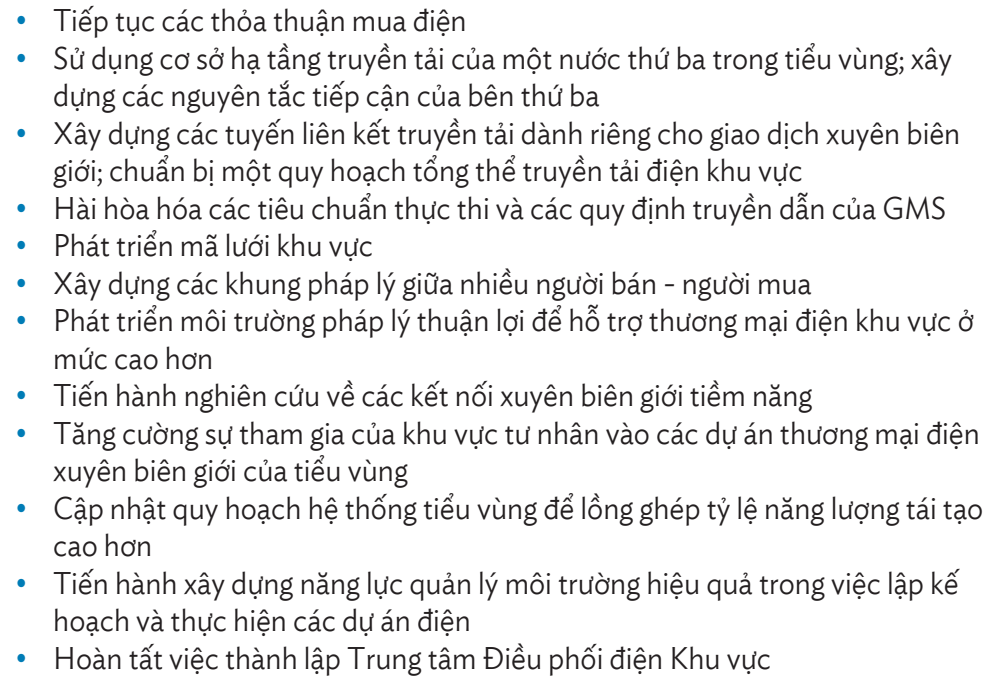 \\
\hline \multicolumn{2}{|l|}{ Nông nghiệp ${ }^{d}$} \\
\hline $\begin{array}{l}\text { - Xây dựng các chính sách, thông lệ và } \\
\text { tiêu chuẩn hài hòa để tạo thuận lợi cho } \\
\text { việc sản xuất, kinh doanh và đầu tư vào } \\
\text { các chuỗi giá trị SEAP }\end{array}$ & $\begin{array}{l}\text { - Hài hòa các tiêu chuẩn liên quan đến (i) thực hành sản xuất tốt trong trồng } \\
\text { trọt, chăn nuôi và nuôi trồng thủy sản, (ii) đảm bảo chất lượng và an toàn } \\
\text { thực phẩm, (iii) các cơ quan chứng nhận và kiểm định (bao gồm PGS cho các } \\
\text { sản phẩm nông nghiệp hữu cơ), (iv) quy trình kiểm dịch và (v) các hệ thống } \\
\text { giám sát và phòng thí nghiệm. } \\
\text { - Xác định và phổ biến các hướng dẫn và thực tiễn tốt nhất liên quan đến } \\
\text { đầu tư trực tiếp nước ngoài trong lĩnh vực thực phẩm và nông nghiệp, canh } \\
\text { tác theo hợp đồng, và quy tắc ứng xử bảo đảm đầu tư cho thực phẩm nông } \\
\text { nghiệp có trách nhiệm vào SEAP xuyên biên giới GMS. } \\
\text { - Xầ dựng và thông qua các chính sách cho SEAP, bao gồm các chính sách } \\
\text { cho NUE, GWM và PGS }\end{array}$ \\
\hline $\begin{array}{l}\text { - Củng cố cơ sở hạ tầng cho các chuỗi giá } \\
\text { trị SEAP tích hợp toàn khu vực }\end{array}$ & $\begin{array}{l}\text { - Xây dựng các khu chế biến nông nghiệp và công viên thực nghiệm nông } \\
\text { nghiệp trong GMS giúp tạo điều kiện cho đầu tư, sản xuất, chế biến và buôn } \\
\text { bán SEAP } \\
\text { - Xây dựng khu kiểm soát bệnh dịch vật nuôi tại biên giới } \\
\text { - Thành lập các cơ sở vệ sinh và kiểm dịch động thực vật (SPS) phù hợp, bao } \\
\text { gồm phòng thí nghiệm tham chiếu và phòng thí nghiệm giám sát trong GMS }\end{array}$ \\
\hline
\end{tabular}


Tiếp theo

\begin{tabular}{|c|c|}
\hline Các ưu tiên hoạt động theo ngành & Các hành động chính \\
\hline $\begin{array}{l}\text { - Xây dựng những phương pháp tiếp thị } \\
\text { để quảng bá danh tiếng của GMS nhu' } \\
\text { một nhà cung cấp SEAP hàng đầu trên } \\
\text { toàn cầu }\end{array}$ & $\begin{array}{l}\text { - Phát triển các cơ sở ươm tạo doanh nghiệp nông nghiệp trong GMS, tập trung } \\
\text { vào gia tăng các doanh nghiệp khởi nghiệp và các DNVVN sáng tạo cho SEAP } \\
\text { - Phát triển và tăng cường mạng lưới nghiên cứu và mở rộng tập trung vào các } \\
\text { thông lệ về chuỗi giá trị và nông học được cải thiện nhắm tăng năng suất, } \\
\text { giảm lãng phí và tổn thất cho các SEAP. } \\
\text { - Xây dựng và tăng cường các trung tâm đào tạo và thực nghiệm trong khu vực } \\
\text { - Phát triển và tăng cường mạng lưới giáo dục và xây dựng năng lực khu vực } \\
\text { liên quan tới chuỗi giá trị và quản lý hậu cần trong mối quan hệ đối tác với các } \\
\text { công ty kinh doanh nông sản } \\
\text { - Phát triển nền tảng chia sẻ thông tin để tạo thuận lợi cho việc trao đổi thông } \\
\text { tin liên quan đến SEAP, các cơ hội kinh doanh và nhận dạng đối tác đầu tư } \\
\text { - Thực hiện các hoạt động tiếp thị chung để quảng bá danh tiếng GMS như là } \\
\text { nhà cung cấp SEAP toàn cầu } \\
\text { - Thúc đẩy xây dựng các chỉ dẫn địa lý cho nông nghiệp và thực phẩm } \\
\text { toàn tựng kế hoạch truyền thông đhẩm và SEAP }\end{array}$ \\
\hline \multicolumn{2}{|l|}{ Môi trườnge } \\
\hline $\begin{array}{l}\text { - Các công nghệ xanh và cơ sở hạ tầng } \\
\text { bền vững được áp dụng ngày càng nhiều } \\
\text { tại các quốc gia GMS }\end{array}$ & $\begin{array}{l}\text { - Đưa ra chính sách môi trường, lập kế hoạch chiến lược và hỗ trợ bảo đảm an } \\
\text { toàn (đánh giá môi trường chiến lược; đánh giá tác động môi trường; các tiêu } \\
\text { chuẩn chất lượng môi trường; các công cụ kinh tế; kiểm soát và khắc phục ô } \\
\text { nhiễm không khí, nước và đất; quản lý chất thải; và phát thải các-bon thấp) } \\
\text { - Thúc đẩy chia sẻ kiến thức và chuyển giao công nghệ sạch hơn (bao gồm sản } \\
\text { xuất sạch hơn; sử dụng tài nguyên và năng lượng hiệu quả; xử lý không khí, } \\
\text { nước và đất, v.v.) } \\
\text { - Hỗ trợ chuẩn bị dự án về: (i) cải thiện và quản lý chất lượng môi trường nông } \\
\text { thôn, (ii) tài trợ vận tải đường bộ xanh và, (iiii) quản lý chất thải điện tử } \\
\text { - Xác định và áp dụng các biện pháp giảm rủi ro đầu tư; kết nối, xây dựng và } \\
\text { tạo ra mối liên kết với các công cụ đánh giá rủi ro và khả năng tổn thương; tạo } \\
\text { thuận lợi cho sự tham gia của khu vực nhà nước và tư nhân thông qua đầu } \\
\text { tư tạo tác động, tài trợ bù đắp thiếu hụt, trái phiếu xanh và các cơ chế tài trợ } \\
\text { sáng tạo khác }\end{array}$ \\
\hline $\begin{array}{l}\text { - Gia tăng đầu tư vào tài nguyên thiên } \\
\text { nhiên và các dịch vụ hệ sinh thái }\end{array}$ & $\begin{array}{l}\text { - Cung cấp hỗ trợ về khung chính sách và pháp lý cho bảo tồn tài nguyên thiên } \\
\text { nhiên và quản lý đất đai bền vững } \\
\text { - Hỗ trợ chia sẻ tri thức khu vực về tài nguyên thiên nhiên và các dịch vụ hệ } \\
\text { sinh thái } \\
\text { - Hỗ trợ quy hoạch tài nguyên đất: quy hoạch không gian tích hợp, đánh giá } \\
\text { hệ sinh thái, định giá và lập bản đồ, đánh giá rủi ro, và tích hợp trong các quy } \\
\text { hoạch và dự án đầu tư chính của ngành } \\
\text { - Hố trợ chuẩn bị dự án về quản lý tổng hợp tài nguyên thiên nhiên và đất đai } \\
\text { cho phát triển bền vững (bảo vệ các hệ sinh thái giá trị cao, phục hồi hoặc } \\
\text { khắc phục đất bị thoái hóa, kiểm soát và khắc phục ô nhiếm đất) } \\
\text { - Xây dựng chính sách tài chính bền vững, các cơ chế hỗ trợ giá và phân phối } \\
\text { lợi ích (chi trả cho các dịch vụ hệ sinh thái có thể áp dụng với ngành du lịch và } \\
\text { các công ty thủy điện, bồi hoàn đa dạng sinh học, v.v.) }\end{array}$ \\
\hline
\end{tabular}


Tiếp theo

\begin{tabular}{|c|c|}
\hline Các ưu tiên hoạt động theo ngành & Các hành động chính \\
\hline $\begin{array}{l}\text { - Thích ứng biến đổi khí hậu và các chiến } \\
\text { lược DRM được tích hợp ngày càng } \\
\text { nhiều trong các kế hoạch đầu tư ngành } \\
\text { của GMS }\end{array}$ & $\begin{array}{l}\text { - Khung pháp lý cho cơ sở hạ tầng thích ứng khí hậu } \\
\text { - Chia sẻ các thông lệ thực hành tốt trong đánh giá và thích nghi CRV trong khu vực } \\
\text { - Hỗ trợ kỹ thuật để tăng cường các đánh giá CRV và DRM trong lập kế hoạch } \\
\text { dự án đầu tư } \\
\text { - Hỗ trợ chuẩn bị dự án bao gồm: (i) đầu tư cho cơ sở hạ tầng nông thôn thích } \\
\text { ứng khí hậu, (ii) DRM và các phương án tài trợ rủi ro, và (iii) cách tiếp cận } \\
\text { chuỗi giá trị để thúc đẩy sự bao trùm về mặt kinh tế và xã hội cho các sáng } \\
\text { - kiến bảo vệ khí hậu } \\
\text { - Thúc đẩy các giải pháp tài trợ rủi ro thiên tai và khí hậu }\end{array}$ \\
\hline \multicolumn{2}{|l|}{ Du lịch ${ }^{f}$} \\
\hline - Phát triển nguồn nhân lực & $\begin{array}{l}\text { - Thực hiện chuẩn kỹ năng vùng } \\
\text { - Xây dựng năng lực cho các quan chức nhà nước } \\
\text { - Tăng cường các dịch vụ của doanh nghiệp du lịch }\end{array}$ \\
\hline - Cải thiện cơ sở hạ tầng du lịch & $\begin{array}{l}\text { - Nâng cấp các cảng hàng không } \\
\text { - Thiết lập kết nối đường bộ tại các điểm đến thứ cấp } \\
\text { - Phát triển các dịch vụ cơ sở hạ tầng đô thị xanh } \\
\text { - Cải thiện các cảng hàng khách đường sông và đường biển } \\
\text { - Mở rộng hệ thống đường sắt xuyên quốc gia }\end{array}$ \\
\hline $\begin{array}{l}\text { - Tăng cường trải nghiệm và các dịch vụ } \\
\text { dành cho du khách }\end{array}$ & $\begin{array}{l}\text { - Thiết lập các quy hoạch điểm đến theo chủ đề và không gian tích hợp } \\
\text { - Xây dựng những trải nghiệm đa quốc gia theo chủ đề } \\
\text { - Áp dụng các tiêu chuẩn du lịch chung } \\
\text { - Tạo thuận lợi cho đầu tư vào các điểm đến thứ cấp } \\
\text { - Ngăn chặn những tác động tiêu cực về xã hội và môi trường }\end{array}$ \\
\hline $\begin{array}{l}\text { - Tiến hành tiếp thị và quảng bá theo cách } \\
\text { sáng tạo }\end{array}$ & $\begin{array}{l}\text { - Thúc đẩy các trải nghiệm và sự kiện đa quốc gia theo chủ đề } \\
\text { - } \quad \text { Định vị GMS như là điểm đến phải ghé thăm ở Châu Á } \\
\text { - Tăng cường các thỏa thuận tiếp thị công - tư } \\
\text { - Tăng cường nghiên cứu thị trường và trao đổi dũ liệu } \\
\text { - Nâng cao nhận thức về các cơ hội và tính bền vững trong du lịch }\end{array}$ \\
\hline $\begin{array}{l}\text { - Tạo thuận lợi cho việc đi lại trong khu } \\
\text { vực }\end{array}$ & $\begin{array}{l}\text { - Vận động thực hiện các thỏa thuận dịch vụ hàng không } \\
\text { - Khắc phục những thiếu hụt trong chính sách thị thực du lịch } \\
\text { - Cải thiện quản lý cơ sở vật chất biên giới }\end{array}$ \\
\hline \multicolumn{2}{|l|}{ Tạo thuận lợi thương mạis } \\
\hline $\begin{array}{l}\text { - Hiện đại hóa hải quan thông qua triển } \\
\text { khai Công ước Kyoto sửa đổi, áp dựng } \\
\text { công nghệ thông tin và quan hệ đối tác } \\
\text { với khu vực tư }\end{array}$ & $\begin{array}{l}\text { - Thực hiện kiểm soát và tuân thủ dựa trên rủi ro được định hướng bởi trí tuệ } \\
\text { - Thúc đầy quan hệ đối tác công tư } \\
\text { - Tăng cường áp dụng các hệ thống xử lý công nghệ thông tin } \\
\text { - Triển khai các cơ chế một cửa quốc gia } \\
\text { - Xây dựng năng lực của cơ quan quản lý hải quan để triển khai những sáng kiến } \\
\text { quan trọng dựa trên các thỏa thuận quốc tế }\end{array}$ \\
\hline $\begin{array}{l}\text { - Đơn giản hóa và chuẩn hóa các tài liệu } \\
\text { thương mại dựa trên các tiêu chuẩn } \\
\text { thương mại quốc tế, và tăng cường phối } \\
\text { hợp giữa các cơ quan }\end{array}$ & $\begin{array}{l}\text { - Thực hiện đơn giản hóa và tiêu chuẩn hóa các tài liệu thương mại } \\
\text { - Tăng cường phối hợp giữa các cơ quan } \\
\text { - Tiến hành các nghiên cứu thời gian giải phóng hàng hóa } \\
\text { - Phát triển cơ sở dữ liệu GMS vê̂̀ tạo thuận lợi thương mại }\end{array}$ \\
\hline - Tăng cường phối hợp quản lý biên giới & $\begin{array}{l}\text { - Tăng cường phối hợp giữa các cơ quan hải quan, SPS, quản lý biên giới và khu } \\
\text { vực tư nhân theo thông lệ quốc tế tốt và các khuôn khổ liên quan khác } \\
\text { - Thực hiện cơ chế kiểm tra một điểm dừng hoặc kiểm tra một cửa }\end{array}$ \\
\hline
\end{tabular}


Tiếp theo

\begin{tabular}{|c|c|}
\hline Các ưu tiên hoạt động theo ngành & Các hành động chính \\
\hline $\begin{array}{l}\text { - Gia tăng các thỏa thuận vệ sinh và kiểm } \\
\text { dịch động thực vật cho thương mại GMS }\end{array}$ & $\begin{array}{l}\text { - Xây dựng năng lực trong các công cụ quản lý (ví dụ: cách tiếp cận dựa trên } \\
\text { rủi ro, phối hợp giữa các cơ quan chính phủ, thúc đẩy quan hệ đối tác với các } \\
\text { ngành và hợp tác với các đối tác trong vùng, cải thiện việc tuân thủ các quy } \\
\text { định SPS trong toàn bộ chuỗi giá trị) }\end{array}$ \\
\hline \multicolumn{2}{|l|}{ Phát triển nguồn nhân lựch } \\
\hline $\begin{array}{l}\text { Y tế } \\
\text { - Thành lập Nhóm công tác về Hợp tác } \\
\text { y tế để đóng vai trò là diễn đàn hợp tác } \\
\text { trong các vấn đề y tế của khu vực; các } \\
\text { lĩnh vực ưu tiên hợp tác về y tế khu vực } \\
\text { có thể bao gồm: kiểm soát các bệnh } \\
\text { truyền nhiễm và an ninh y tế; mở rộng } \\
\text { phạm vi chăm sóc sức khỏe toàn dân; } \\
\text { hợp tác khu vực và các dịch vụ y tế cho } \\
\text { nhóm dân di cư và lưu động. }\end{array}$ & $\begin{array}{l}\text { - Triển khai Nhóm công tác về Hợp tác Y tế } \\
\text { - Xây dựng và thực hiện Chiến lược Hợp tác Y tế GMS } \\
\text { - Thúc đẩy chia sẻ tri thức về hợp tác y tế khu vực } \\
\text { - Xây dựng danh mục dự án đề xuất }\end{array}$ \\
\hline $\begin{array}{l}\text { Phát triển xã hội } \\
\text { - Xác định những vấn đề xuyên suốt trong } \\
\text { các ngành và dự án mà có thể gắn với } \\
\text { các hoạt động khác }\end{array}$ & - Lồng ghép các vấn đề phát triển xã hội vào trong các lĩnh vực và dự án \\
\hline $\begin{array}{l}\text { Lao động và di cư trong GMS } \\
\text { - Cần được dẫn dắt ở cấp độ dự án }\end{array}$ & $\begin{array}{l}\text { - Được dẫn dắt bởi Tổ chức Di cư Thế giới với dự án Giảm nghèo thông qua } \\
\text { Phát triển Kỹ năng cho Di cư thường xuyên và an toàn tại Cam-pu-chia, } \\
\text { CHDCND Lào, Mi-an-ma, Thái Lan và Việt Nam (PROMISE), đây là dự án } \\
\text { được triển khai trong } 8 \text { năm cho tới năm } 2024\end{array}$ \\
\hline $\begin{array}{l}\text { Giáo dục và đào tạo kỹ thuật và dạy nghề } \\
\text { • Cần được theo đuổi ở cấp độ các hoạt } \\
\text { động quốc gia và song phương }\end{array}$ & $\begin{array}{l}\text { - Theo đuổi hợp tác giáo dục nghề nghiệp (TVET) ở cấp độ các hoạt động } \\
\text { quốc gia và song phương } \\
\text { - Tiến hành phân tích các vấn đề TVET của khu vực }\end{array}$ \\
\hline \multicolumn{2}{|l|}{ Công nghệ thông tin và truyền thông' } \\
\hline - Xây dựng một chiến lược CNTT mới & $\begin{array}{l}\text { - Thành lập nhóm đặc trách để xác định định hướng và phương thức hợp tác } \\
\text { CNTT trong tương lai cho GMS } \\
\text { - Xây dựng chiến lược phát triển CNTT mới } \\
\text { - Củng cố CNTT như một lĩnh vực xuyên suốt để hỗ trợ các ngành và xác định } \\
\text { cơ chế phối hợp cho mục đích này } \\
\text { - Thúc đẩy các ứng dụng CNTT } \\
\text { - Triển khai các hoạt động xây dựng năng lực và thiết lập mạng lưới giữa các } \\
\text { chuyên gia CNTT trong GMS }\end{array}$ \\
\hline $\begin{array}{l}\text { - Tăng cường Nền tảng hợp tác Thương } \\
\text { mại điện tử GMS }\end{array}$ & $\begin{array}{l}\text { - Tăng cường hỗ trợ và vận động chính sách } \\
\text { - Thúc đẩy sự tham gia vào nền tảng } \\
\text { - Khuyến khích các nhóm công tác theo ngành của GMS liên kết với nền tảng } \\
\text { - khi thích hợp } \\
\text { - Chia sẻ thông tin (cơ sở dữ liệu và các thị trường tiêu dùng) }\end{array}$ \\
\hline
\end{tabular}

$\mathrm{CRV}=$ dễ tổn thương trước rủi ro khí hậu, $\mathrm{DRM}=$ quản lý rủi ro thiên tai, EWEC = Hành lang kinh tế Đông - Tây, GMS = Tiểu vùng Mê-kông mở rộng, GWM = quản lý nước xanh, ICD = cảng thông quan hoặc cảng công-ten-nơ quốc tế, CNTT = công nghệ thông tin và truyền thông, $C H D C N D$ Lào = Cộng hòa Dân chủ Nhân dân Lào, NSEC = Hành lang kinh tế Bắc - Nam, NUE = hiệu quả sử dụng nitơ, $\mathrm{PGS}$ = hệ thống đảm bảo sự tham gia, $\mathrm{SEAP}=$ sản phẩm nông nghiệp an toàn và thân thiện với môi trường, $\mathrm{SEC}=\mathrm{Hành}$ lang kinh tế phía Nam, SPS = vệ sinh và kiểm dịch động thực vật, TVET = giáo dục nghề nghiệp.

a Đối với ngành vận tải, các hành động chính được dựa trên ADB. 2017. Tài liệu Transport Sector Strategy 2030 (dự thảo). Manila; ADB. 2017. Tóm tắt Kỷ yếu hội thảo. Diễn đàn Giao thông Tiểu vùng GMS lần thứ 21. Ngày 19 - 20/7/2017. Luang Prabang, CHDCND Lào; và các tài liệu liên quan. 
b Đối với phát triển đô thị, các lĩnh vực đa ngành và các khu kinh tế cửa khẩu, các hành động chính được dựa trên ADB. 2015. Tài liệu Urban Development Strategic Framework, 2015-2022. Manila; thảo luận nhóm trọng điểm trong hội nghị truyền hình về Thông tin Phát triển đô thị: Lưu ý và trọng tâm thảo luận, ngày 26/5/2017; ADB. 2017. Tài liệu Summary of Proceedings. Hội nghị lần thứ nhất Nhóm công tác Phát triển đô thị. Ngày 28 - 29/6/2017. Hà Nội, Việt Nam; và các tài liệu liên quan.

c Đối với ngành năng lượng, các hành động chính được dựa trên ADB. 2012. Tài liệu Energy Sector Strategy in the GMS Strategic Framework 2012-2022. Manila; ADB. 2002. Thỏa thuận liên chính phủ về thương mại điện khu vực trong GMS. Phnom Penh, Cam-pu-chia; ADB. 2004. Tài liệu Regional Power Trade Operation Agreement. Manila; thảo luận nhóm trọng điểm trong hội nghị truyền hình về Thông tin Năng lượng: Lưu ý và trọng tâm thảo luận, ngày 11/5/2017 (hội nghị truyền hình); ADB. 2017. Tài liệu Summary of Proceedings. Hội nghị lần thứ 22 của Ủy ban Điều phối thương mại điện khu vực. Ngày 20 - 21/6/2017. Thành Đô, Tú Xuyên, Cộng hòa Nhân dân Trung Hoa; và các tài liệu liên quan.

d Đối với nông nghiệp, các hành động chính được dựa trên ADB. 2017. Tài liệu Strategy for Promoting Safe and Environment-friendly Agro-based Value Chains in the Greater Mekong Subregion and Siem Reap Action Plan, 2018-2022. Manila; ADB. 2017. Tài liệu Summary of Proceedings. Hội nghị lần thứ 14 của Nhóm công tác Nông nghiệp. Ngày 13 - 14/7/2017. Siêm Riệp, Cam-pu-chia; và các tài liệu liên quan.

e Đối với lĩnh vực môi trường, các hành động chính được dựa trên ADB. Sắp phát hành. Tài liệu Core Environment Program Strategic Framework and Action Plan, 2018-2022. Manila; ADB. 2017. Tài liệu Summary of Proceedings. Hội nghị lần thứ 23 của Nhóm công tác Môi trường. Ngày 11 - 12/7/2017. Siêm Riệp, Cam-pu-chia; và các tài liệu liên quan.

f Đối với du lịch, các hành động chính được dựa trên Văn phòng Điều phối du lịch Mê-kông. Tài liệu Tourism Sector Strategy, 2016-2025. Thái Lan; ADB. 2017. Tài liệu Summary of Proceedings. Hội nghị lần thứ 39 của Nhóm công tác Du lịch. Ngày 5/6/2017. Luang Prabang, CHDCND Lào; và các tài liệu liên quan.

g Đối với tạo thuận lợi thương mại, các hành động chính được dựa trên ADB. 2012. Tài liệu Transport and Trade Facilitation Action Program, 2015-2017. Manila; thảo luận nhóm trọng điểm trong hội nghị truyền hình về Thông tin Tạo thuận lợi thương mại (SPS và Hải quan): Lưu ý và trọng tâm thảo luận, ngày 11/5/2017; và rà soát các báo cáo hỗ trợ kỹ thuật của ADB và các tài liệu liên quan.

h Đối với lĩnh vực phát triển nguồn nhân lực, các hành động chính được dựa trên ADB. 2017. Tài liệu Implementation Review of the Strategic Framework and Action Plan for Human Resource Development (HRD) 2013-2017. Manila; thảo luận nhóm trọng điểm trong hội nghị truyền hình về Thông tin Phát triển nguồn nhân lực: Lưu ý và trọng tâm thảo luận, ngày 9/5/2017; ADB. 2017. Tài liệu Summary of Proceedings. Phiên họp bất thường của Nhóm công tác Phát triển nguồn nhân lực, ngày 4/7/2017. Bangkok, Thái Lan; các tài liệu liên quan; và các thảo luận tại Hội nghị Giáo dục nghề nghiệp ở Đông Nam Á: Các chiến lược cho hoạch định hợp tác. Ngày 14/9/2017. Bangkok, Thái Lan.

' Đối với công nghệ thông tin và truyền thông, các hành động chính được dựa trên ADB. 2012. Tài liệu ICT Strategy in the GMS Strategic Framework 2012-2022. Manila; 2011. Khung chiến lược Phát triển CNTT trong GMS. Tài liệu chuẩn bị cho Hội nghị Bộ trưởng Viễn thông GMS. Tây An, Trung Quốc, ngày 8 tháng 6; Biên bản Ghi nhớ về Xa lộ thông tin. Nay Pyi Taw, Mi-an-ma; và rất nhiều báo cáo về Liên minh doanh nghiệp và Nền tảng hợp tác Thương mại điện tử GMS.

Nguồn: Ngân hàng Phát triển Châu Á. 


\section{Kế hoạch Hành động Hà Nội giai đoạn 2018-2022}

Kế hoạch Hành động Hà Nội giai đoạn 2018-2022 (HAP) giải quyết chương trình nghị sự chưa hoàn thành và mở rộng của Chương trình Hợp tác kinh tế Tiểu vùng Mê-kông mở rộng (GMS) cho 5 năm còn lại của Khung chiến lược GMS giai đoạn 2012-2022. Kế hoạch Hành động Hà Nội cung cấp định hướng và trọng tâm hoạt động cho Chương trình GMS và hướng dẫn xác định các dự án trong lĩnh vực giao thông, phát triển đô thị, năng lượng, nông nghiệp, môi trường, du lịch, tạo thuận lợi thương mại, phát triển nguồn nhân lực và công nghệ thông tin và truyền thông. Những thành phần chủ chốt của HAP gồm: chiến lược không gian tập trung vào các hành lang kinh tế; tinh chỉnh các chiến lược và ưu tiên theo ngành; cải thiện các hệ thống và quy trình lập kế hoạch, xây dựng chương trình và giám sát; và cải tiến những sắp xếp thể chế và quan hệ đối tác.

\section{Ngân hàng Phát triển Châu Á}

Tầm nhìn của $A D B$ là một khu vực Châu Á và Thái Bình Dương không còn nghèo khổ. Sứ mệnh của $A D B$ là hỗ trợ các quốc gia thành viên đang phát triển giảm nghèo và nâng cao chất lượng cuộc sống của người dân. Mặc dù đã đạt được nhiều thành công, khu vực này vẫn là nơi sinh sống của phần lớn người nghèo trên thế giới. $\mathrm{ADB}$ cam kết giảm nghèo thông qua tăng trưởng kinh tế đồng đều, tăng trưởng bền vưng với môi trường, và hội nhập khu vực.

Có trụ sở chính tại Ma-ni-la, ADB thuộc sở hữu của 67 thành viên, trong đó có 48 thành viên trong khu vực. Những công cụ chính để hỗ trợ các quốc gia thành viên đang phát triển là đối thoại chính sách, khoản vay, đầu tư cổ phần, bảo lãnh, viện trợ không hoàn lại và hỗ trợ kỹ thuật.

\section{Chương trình Hợp tác kinh tế Tiểu vùng Mê-kông mở rộng}

Tiểu vùng Mê-kông mở rộng (GMS) bao gồm Cam-pu-chia, Cộng hòa Nhân dân Trung Hoa (cụ thể là tỉnh Vân Nam và Khu tự trị dân tộc Choang Quảng Tây), Cộng hòa Dân chủ nhân dân Lào, Mi-an-ma, Thái Lan và Việt Nam. Năm 1992, với sự hỗ trợ của Ngân hàng Phát triển Châu Á và dựa trên những tương đồng về lịch sử và văn hóa, sáu quốc gia của Tiểu vùng Mê-kông mở rộng đã khởi động một chương trình hợp tác kinh tế tiểu vùng - Chương trình GMS - để tăng cường các quan hệ kinh tế, với chín lĩnh vực ưu tiên ban đầu gồm: nông nghiệp, năng lượng, môi trường, phát triển nguồn nhân lực, đầu tư, viễn thông, du lịch, cơ sở hạ tầng giao thông, và tạo thuận lợi thương mại và giao thông.

$\mathrm{ADB}$

\section{NGÂN HÀNG PHÁT TRIỂN CHÂU Á}

6 ADB Avenue, Mandaluyong City

1550 Metro Manila, Philippines

www.adb.org 